Prepared in cooperation with the International Joint Commission, North Dakota Department of Environmental Quality, and Minnesota Pollution Control Agency and in collaboration with Manitoba Sustainable Development and Environment and Climate Change Canada

\title{
Water-Quality Trends for Selected Sites and Constituents in the International Red River of the North Basin, Minnesota and North Dakota, United States, and Manitoba, Canada, 1970-2017
}

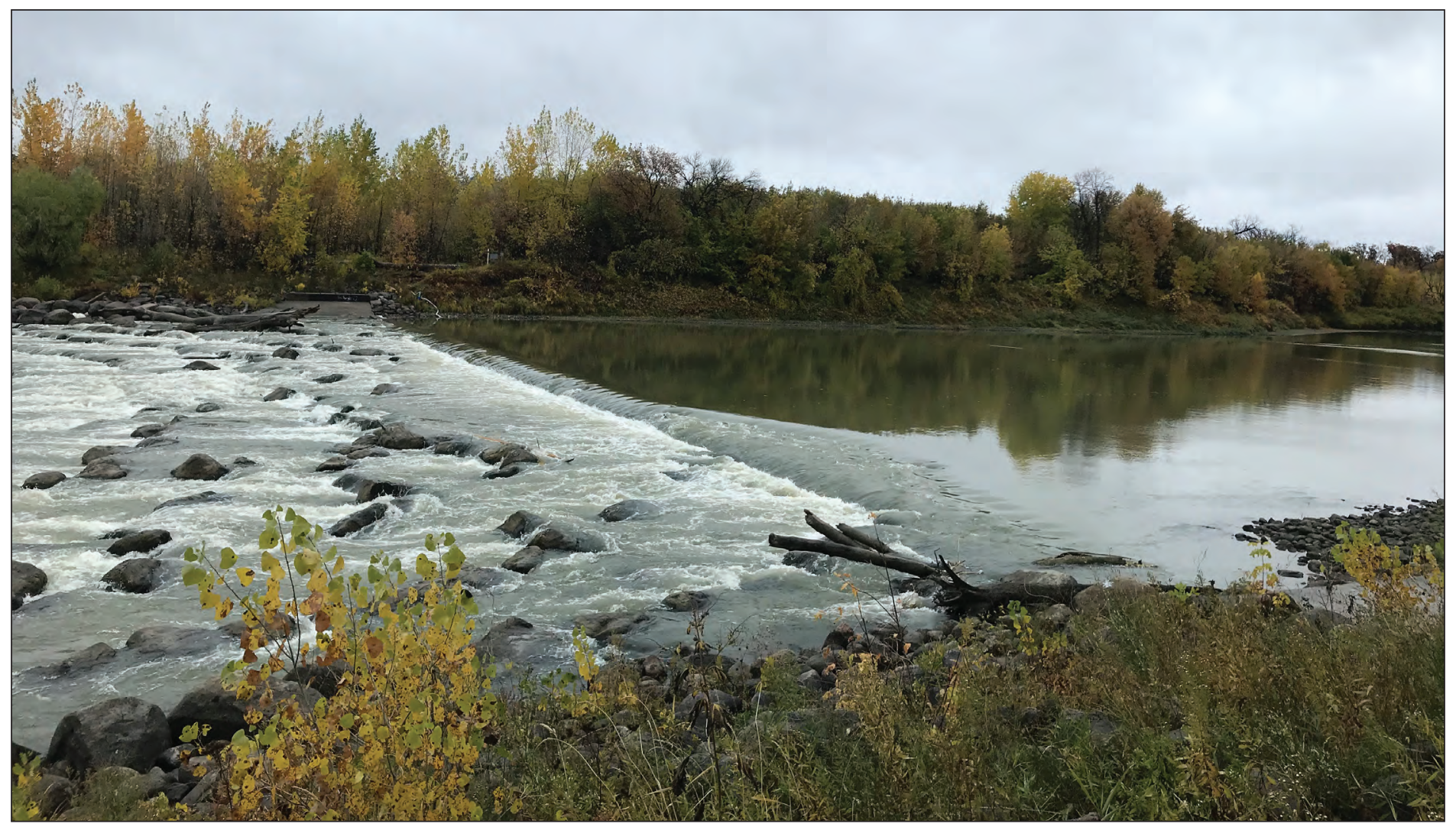

Scientific Investigations Report 2020-5079 
Cover. Photograph showing Riverside Dam on the Red River of the North, Grand Forks, North Dakota, taken October 9, 2018, by Ernest McCoy, U.S. Geological Survey. 


\section{Water-Quality Trends for Selected Sites and Constituents in the International Red River of the North Basin, Minnesota and North Dakota, United States, and Manitoba, Canada, 1970-2017}

By Rochelle A. Nustad and Aldo V. Vecchia

Prepared in cooperation with the International Joint Commission, North Dakota Department of Environmental Quality, and Minnesota Pollution Control Agency and in collaboration with Manitoba Sustainable Development and Environment and Climate Change Canada

Scientific Investigations Report 2020-5079 


\section{U.S. Department of the Interior \\ DAVID BERNHARDT, Secretary}

\section{U.S. Geological Survey James F. Reilly II, Director}

\section{U.S. Geological Survey, Reston, Virginia: 2020}

For more information on the USGS - the Federal source for science about the Earth, its natural and living resources, natural hazards, and the environment—visit https://www.usgs.gov or call 1-888-ASK-USGS.

For an overview of USGS information products, including maps, imagery, and publications, visit https://store.usgs. gov/.

Any use of trade, firm, or product names is for descriptive purposes only and does not imply endorsement by the U.S. Government.

Although this information product, for the most part, is in the public domain, it also may contain copyrighted materials as noted in the text. Permission to reproduce copyrighted items must be secured from the copyright owner.

Suggested citation:

Nustad, R.A., and Vecchia, A.V., 2020, Water-quality trends for selected sites and constituents in the international Red River of the North Basin, Minnesota and North Dakota, United States, and Manitoba, Canada, 1970-2017: U.S. Geological Survey Scientific Investigations Report 2020-5079, 75 p., https://doi.org/10.3133/sir20205079.

Associated data for this publication:

Nustad, R.A., 2020, Water-quality and streamflow data for United States and Canadian sites in the Red River Basin and scripts for trend analysis-Data supporting water-quality trend analysis in the Red River of the North Basin, 1970-2017: U.S. Geological Survey data release, https://doi.org/10.5066/P9C9JAMY.

U.S. Geological Survey, 2019, USGS water data for the Nation: U.S. Geological Survey National Water Information System database, https://doi.org/10.5066/F7P55KJN.

ISSN 2328-0328 (online) 


\section{Acknowledgments}

The authors gratefully acknowledge funding provided by the International Joint Commission, North Dakota Department of Environmental Quality, and Minnesota Pollution Control Agency. The authors thank Manitoba Sustainable Development and Environment and Climate Change Canada for assistance with water-quality and streamflow data for Canadian sites. The authors gratefully acknowledge the support of the International Red River Board, particularly members of the water-quality committee. Committee members include representatives from many jurisdictions in the international Red River of the North Basin. Insightful comments were provided on the report by Nicole Armstrong and Daniel Rheault (Manitoba Sustainable Development), Aaron Larsen and Joseph Nett (North Dakota Department of Environmental Quality), and Sharon Reedyk (Environment and Climate Change Canada). The authors sincerely thank all field personnel and science-support staff in the Red River of the North Basin who collect and quality assure water-quality and streamflow data, making this type of analysis possible.

The authors also wish to thank Harper Wavra and Todd Anderson with the U.S. Geological Survey for invaluable help with the figures and tables. Insightful comments were provided on the report by Sara Eldridge and Gregg Wiche (U.S. Geological Survey). 



\section{Contents}

Acknowledgments ……...................................................................................................................

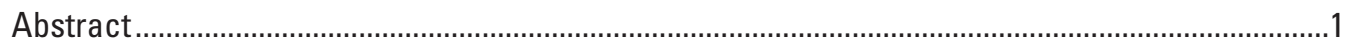

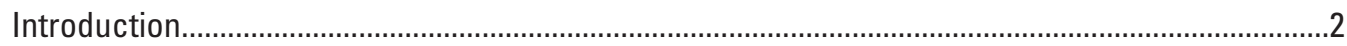

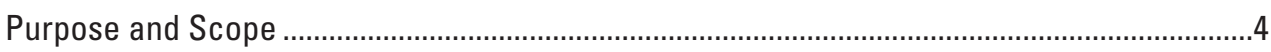

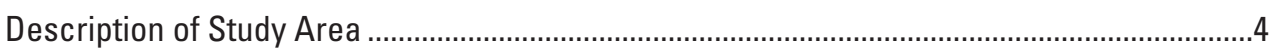

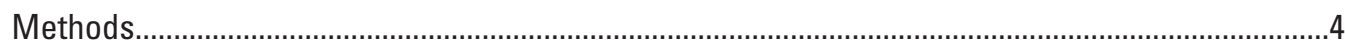

Site and Constituent Selection ...........................................................................................

Water-Quality Data Compilation ...............................................................................................

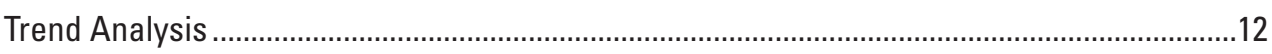

Water-Quality Trends for Selected Sampling Sites in the Red River of the North Basin.................14

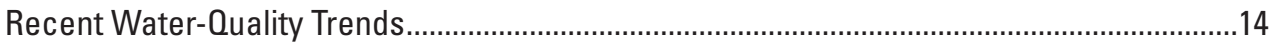

Sulfate, Chloride, and Total Dissolved Solids .................................................................15

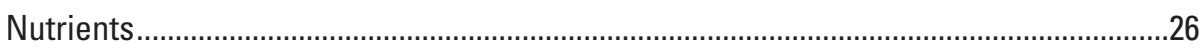

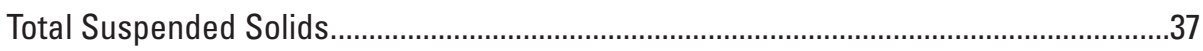

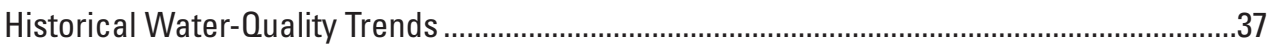

Sulfate and Total Dissolved Solids .................................................................................4

Nitrate Plus Nitrite and Total Phosphorus .........................................................................4

Water-Quality Conditions at the Binational Site ………...............................................................47

Annual Geometric Mean Concentration ............................................................................

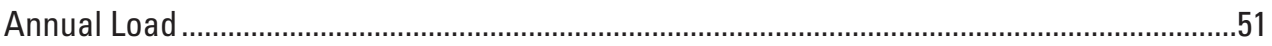

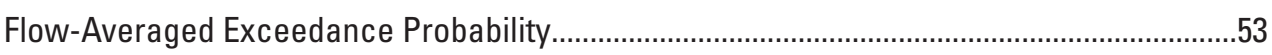

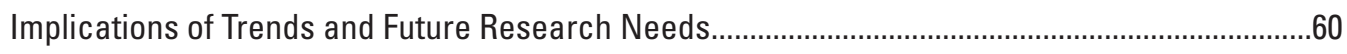

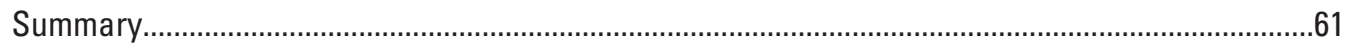

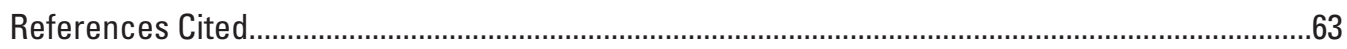

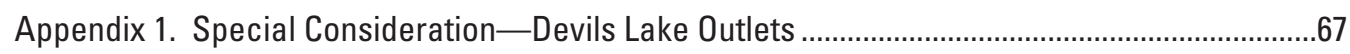

\section{Figures}

1. Map showing location of study area and sampling sites in the Red River of the North Basin, Minnesota, North Dakota, and Manitoba, Canada .........................................3

2. Map showing direction and significance of trends in sulfate concentration evaluated for the recent period 2000-15 at selected sites in the Red River of the North Basin.

3. Graphs showing trends in sulfate concentration evaluated for the recent period 2000-15 at selected sites in the Red River of the North Basin.

4. Map showing direction and significance of trends in chloride concentration evaluated for the recent period 2000-15 at selected sites in the Red River of the North Basin.

5. Graphs showing trends in chloride concentration evaluated for the recent period 2000-15 at selected sites in the Red River of the North Basin.

6. Map showing direction and significance of trends in total dissolved solids concentration evaluated for the recent period 2000-15 at selected sites in the Red River of the North Basin 
7. Graphs showing trends in total dissolved solids concentration evaluated for the recent period 2000-15 at selected sites in the Red River of the North Basin ...

8. Map showing direction and significance of trends in nitrate-plus-nitrite concentration evaluated for the recent period 2000-15 at selected sites in the Red River of the North Basin

9. Graphs showing trends in nitrate-plus-nitrite concentration evaluated for the recent period 2000-15 at selected sites in the Red River of the North Basin ...

10. Map showing direction and significance of trends in total nitrogen concentration evaluated for the recent period 2000-15 at selected sites in the Red River of the North Basin

11. Graphs showing trends in total nitrogen concentration evaluated for the recent period 2000-15 at selected sites in the Red River of the North Basin

12. Map showing direction and significance of trends in total phosphorus concentration evaluated for the recent period 2000-15 at selected sites in the Red River of the North Basin

13. Graphs showing trends in total phosphorus concentration evaluated for the recent period 2000-15 at selected sites in the Red River of the North Basin ......

14. Map showing direction and significance of trends in total suspended solids concentration evaluated for the recent period 2000-15 at selected sites in the Red River of the North Basin

15. Graphs showing trends in total suspended solids concentration evaluated for the recent period 2000-15 at selected sites in the Red River of the North Basin

16. Graph showing fitted trend in annual flow-averaged geometric mean concentration of sulfate evaluated for the historical period 1970-2015 at selected sites in the Red River of the North Basin .....

17. Graph showing fitted trend in annual flow-averaged geometric mean concentration of total dissolved solids evaluated for the historical period 1970-2015 at selected sites in the Red River of the North Basin

18. Graph showing fitted trend in annual flow-averaged geometric mean concentration of nitrate plus nitrite evaluated for the historical period 1970-2017 at selected sites in the Red River of the North Basin

19. Graph showing fitted trend in annual flow-averaged geometric mean concentration of total phosphorus evaluated for the historical period 1970-2015 at selected sites in the Red River of the North Basin.

20. Graphs showing annual geometric mean concentration and fitted trends in annual flow-averaged geometric mean concentration for the historical period 1970-2015 at the binational site, Red River of the North at Emerson, Manitoba

21. Graphs showing annual geometric mean concentration and fitted trends in annual flow-averaged geometric mean concentration for the historical period 1970-2015 at the binational site, Red River of the North at Emerson, Manitoba

22. Graphs showing annual load and fitted trend in annual flow-averaged load for the historical period 1970-2015 at the binational site, Red River of the North at Emerson, Manitoba

23. Graphs showing annual load and fitted trend in annual flow-averaged load for the historical period 1970-2015 at the binational site, Red River of the North at Emerson, Manitoba

24. Graphs showing flow-averaged exceedance probability and fitted trend in flow-averaged exceedance probability evaluated for the sulfate water-quality objective of 250 milligrams per liter at the binational site, Red River of the North at Emerson, Manitoba 
25. Graphs showing flow-averaged exceedance probability and fitted trend in flow-averaged exceedance probability evaluated for the chloride water-quality objective of 100 milligrams per liter at the binational site, Red River of the North at Emerson, Manitoba.

26. Graphs showing flow-averaged exceedance probability and fitted trend in flow-averaged exceedance probability evaluated for the total dissolved solids water-quality objective of 500 milligrams per liter at the binational site, Red River of the North at Emerson, Manitoba..

27. Graphs showing flow-averaged exceedance probability and fitted trend in flow-averaged exceedance probability evaluated for the proposed total nitrogen water-quality objective of 1.15 milligrams per liter at the binational site, Red River of the North at Emerson, Manitoba.....

28. Graphs showing flow-averaged exceedance probability and fitted trend in flow-averaged exceedance probability evaluated for the proposed total phosphorus water-quality objective of 0.15 milligram per liter at the binational site, Red River of the North at Emerson, Manitoba..

\section{Tables}

1. Sites selected for trend analysis and sources of data in the Red River of the North Basin, Minnesota, North Dakota, and Manitoba, Canada.

2. Statistical summary of water-quality data collected during 1995-2017 for selected sites in the Red River of the North Basin, Minnesota and North Dakota, United States, and Manitoba, Canada

3. Summary of trend results evaluated for the recent period 2000-15 based on data collected during 1997-2017 for sulfate, chloride, total dissolved solids, nitrate-plus-nitrite, total nitrogen, total phosphorus, and total suspended solids concentrations at selected sites in the Red River of the North Basin, Minnesota and North Dakota, United States, and Manitoba, Canada.

4. Summary of trend results evaluated for the historical period 1970-2015 based on data collected during 1970-2017 for sulfate, total dissolved solids, nitrate plus nitrite, and total phosphorus at selected sites in the Red River of the North Basin.

5. Summary of trend results and annual loads evaluated for the historical period 1970-2015 based on data collected during 1970-2017 for sulfate, chloride, total dissolved solids, total nitrogen, and total phosphorus for the binational site, Red River of the North at Emerson, Manitoba 


\section{Conversion Factors}

U.S. customary units to International System of Units

\begin{tabular}{lll}
\hline \multicolumn{1}{c}{ Multiply } & \multicolumn{1}{c}{ By } & \multicolumn{1}{c}{ To obtain } \\
\hline foot $(\mathrm{ft})$ & \multicolumn{1}{c}{ Length } & \\
mile $(\mathrm{mi})$ & 0.3048 & meter $(\mathrm{m})$ \\
& 1.609 & kilometer $(\mathrm{km})$ \\
\hline square mile $\left(\mathrm{mi}^{2}\right)$ & Area & \\
square mile $\left(\mathrm{mi}^{2}\right)$ & 259.0 & hectare $(\mathrm{ha})$ \\
\hline & 2.590 & square kilometer $\left(\mathrm{km}^{2}\right)$ \\
\hline cubic foot per second $(\mathrm{ft} 3 / \mathrm{s})$ & Flow rate & \\
\hline
\end{tabular}

International System of Units to U.S. customary units

\begin{tabular}{lll}
\hline \multicolumn{1}{c}{ Multiply } & \multicolumn{1}{c}{ By } & \multicolumn{1}{c}{ To obtain } \\
\hline & Flow rate & \\
\hline metric ton per year $(\mathrm{t} / \mathrm{yr})$ & 1.102 & ton, short $[2,000 \mathrm{lb}]$, per year \\
metric ton per year $(\mathrm{t} / \mathrm{yr})$ & 0.9842 & ton, long $[2,240 \mathrm{lb}]$, per year \\
\hline
\end{tabular}

\section{Datum}

Vertical coordinate information is referenced to North American Vertical Datum of 1988 (NAVD 88).

Horizontal coordinate information is referenced to North American Datum of 1983 (NAD 83).

\section{Supplemental Information}

Concentrations of chemical constituents in water are given in milligrams per liter (mg/L). 


\title{
Abbreviations
}

\author{
CRP Conservation Reserve Program \\ $C(t) \quad$ constituent concentration for time step $(t)$ \\ ECCC Environment and Climate Change Canada \\ FAEP flow-averaged exceedance probability \\ FAGMC flow-averaged geometric mean concentration \\ FRVAR variable from R-QWTREND which captures flow-related variability \\ GMC geometric mean concentration \\ IJC International Joint Commission \\ IRRB International Red River Board \\ MPCA Minnesota Pollution Control Agency \\ MSD Manitoba Sustainable Development \\ NDDEO North Dakota Department of Environmental Quality \\ $p \quad$ probability \\ $t \quad$ time step \\ USGS U.S. Geological Survey \\ W0O water-quality objective \\ WQP Water Quality Portal \\ WSC Water Survey of Canada
}





\title{
Water-Quality Trends for Selected Sites and Constituents in the International Red River of the North Basin, Minnesota and North Dakota, United States, and Manitoba, Canada, 1970-2017
}

\author{
By Rochelle A. Nustad and Aldo V. Vecchia
}

\section{Abstract}

A comprehensive study to evaluate water-quality trends, while considering natural hydroclimatic variability, in the Red River of the North Basin and assess water-quality conditions for the Red River of the North crossing the international boundary near Emerson, Manitoba, Canada (the binational site), was completed by the U.S. Geological Survey in cooperation with the International Joint Commission, North Dakota Department of Environmental Quality, and Minnesota Pollution Control Agency and in collaboration with Manitoba Sustainable Development and Environment and Climate Change Canada. The international Red River of the North Basin encompasses 3 U.S. States (South Dakota, North Dakota, and Minnesota) and 1 Canadian Province (Manitoba). Water quality in the Red River of the North Basin is of concern for both Federal governments and State and Provincial governments. Water-quality objectives have been previously established for selected dissolved ions and recently (2019) proposed for selected nutrients for the binational site.

In the current (2020) study, water-quality data from State, Provincial, and Federal agencies in the United States and Canada for sites in the Red River of the North Basin from 1970 to 2017 were compiled and used for trend analysis. Trend analysis using a water-quality dataset from multiple agencies that collect water-quality data for various objectives presented multiple challenges. The trend-analysis approach was able to accommodate differences in water-quality data caused by field-collection and laboratory-analytical method differences, disparities in sampling frequencies, and spatial and temporal gaps in data. Most of these challenges were overcome by the statistical tool, R-QWTREND, which identifies trends in concentration unrelated to variability in streamflow.

The integrated basin approach used in the current study, combined with comparing current data trends with historical trends, provided valuable insights into understanding how water quality is changing spatially (34 sites analyzed for a recent period, 2000-15) and temporally (5 sites analyzed for a 45-year historical period, 1970-2015) within the Red River of the North Basin. One of the most consistent spatial and temporal changes observed in the current study was increasing concentrations of sulfate among tributary and main-stem sites since 2000. For some sites, increases were detected starting as early as 1985 . Total dissolved solids and chloride concentrations had spatial and temporal patterns like sulfate. Although R-QWTREND removes the variability in constituent concentration caused by natural streamflow variability, all variability in sulfate caused by hydroclimatic variability may not be captured because of changes in hydrologic pathways and changes in the contributions of sulfate from various natural sources.

Nutrient concentrations demonstrated less consistent spatial and temporal changes than sulfate, and changes in nutrient concentrations were assumed to be more closely tied to human-induced rather than natural changes. Nitrate-plusnitrite concentrations were mostly increasing in the upper Red River of the North subbasin, and for nitrate plus nitrite and total nitrogen, the Sheyenne River subbasin had consistent decreasing concentrations. Since 2000, total phosphorus has decreased in the upper Red River of the North subbasin, but total phosphorus concentration has increased for sites in the lower Red River of the North subbasin, and for some mainstem sites, concentrations have been increasing since 1985 . Unlike sulfate, the pattern in historical trends for total phosphorus for the main-stem sites differed from tributary sites, indicating that human-induced changes affected tributaries and main-stem sites differently.

The more detailed evaluation of flow-averaged waterquality conditions for the binational site provided an understanding of how loads have changed over time and what proportion of the year and season concentrations are expected to exceed water-quality objectives. In a basin with highly variable streamflow like the Red River of the North, the trend in flow-averaged load (assuming streamflow conditions are the same year after year) provided a robust measure of change over time. Increasing concentrations of sulfate, chloride, total dissolved solids, and total phosphorus since 1985 for the binational site resulted in longer periods of exceedance of 
water-quality objectives per year occurring over time. For total nitrogen, decreasing concentrations resulted in shorter periods of exceedance per year during 1980 to 2015 , but concentrations were still expected to exceed the water-quality objective about half the year. Periods of when exceedances were likely to occur during the year were affected by the source and transport mechanisms of the constituent.

Trend results from this effort identified how water quality has changed across the basin, and further investigation would help to identify causes for the trends observed here. Information from the current study provides a basis for future trend attribution studies, evaluation of water-quality objectives, and development of comprehensive strategies for reducing nutrients to desired targets and establishes a baseline for tracking future progress in the Red River of the North Basin.

\section{Introduction}

The international Red River of the North Basin (hereafter referred to as the "basin") encompasses 3 U.S. States (South Dakota, North Dakota, and Minnesota), and 1 Canadian Province (Manitoba; fig. 1). Water quality in the Red River of the North (hereafter referred to as the "Red River") is of concern for both Federal governments as well as State and Provincial governments. Nutrient enrichment and degrading ecosystem health in Lake Winnipeg have occurred over time with increasing frequency and intensity of algal blooms since the 2000s, and although only 16 percent of the inflow to Lake Winnipeg is from the Red River, the Red River contributes 68 and 34 percent of the total phosphorus and total nitrogen load, respectively (Environment Canada and Manitoba Water Stewardship, 2011). Federal, State, and Provincial agencies establish water-quality standards for their respective jurisdictions, but for international boundary waters, through Article IX of the Boundary Waters Treaty, the International Joint Commission (IJC) is tasked with investigating boundary and transboundary water quality between the United States and Canada (Gabriel and Benoy, 2016).

Water-quality objectives (WQOs) for the Red River crossing the international boundary near Emerson, Manitoba (fig. 1; hereafter referred to as the "binational site"), were established in 1969 for the selected dissolved ions of sulfate, chloride, and total dissolved solids, and nutrient WQOs were proposed in 2019 (hereafter, WQOs proposed in 2019 are referred to as "proposed WQOs"). The IJC recommended WQOs for dissolved ions to U.S. and Canadian governments for the binational site in 1967 based on a report submitted by the International Red River Water Pollution Board (an early version of the current [2020] International Red River Board [IRRB]), and the governments approved and accepted the WQOs in 1969 (Gabriel and Benoy, 2016). The IRRB is one of four IJC boards that are mandated to report on selected water-quality constituents at an international boundary location. The WQOs set in 1969 were intended to protect the ecological health of the water body and to establish a benchmark against which to compare current conditions (Gabriel and Benoy, 2016). WQOs for sulfate, chloride, and total dissolved solids are 250 milligrams per liter $(\mathrm{mg} / \mathrm{L}), 100 \mathrm{mg} / \mathrm{L}$, and $500 \mathrm{mg} / \mathrm{L}$, respectively. Exceedance of these WQOs is measured by calculating the percentage of samples collected in a calendar year at the binational site that have concentrations higher than the WQO. In the last 10-15 years, the WQOs for sulfate and total dissolved solids frequently have been exceeded. In 2011, the Water Quality Committee of the IRRB was formed to develop an approach to a basinwide nutrient management strategy for the basin (individual jurisdictions also were independently working to address nutrient issues in the basin), which included the development of WQOs at the binational site (International Red River Board, 2011). In 2019, with the goal of protecting the Red River and Lake Winnipeg, the Water Quality Committee recommended the following nutrient WQOs to the IRRB for the binational site as concentration objectives and load targets: $1.15 \mathrm{mg} / \mathrm{L}$ for total nitrogen, $0.15 \mathrm{mg} / \mathrm{L}$ for total phosphorus, 9,525 metric tons per year for total nitrogen, and 1,400 metric tons per year for total phosphorus (International Red River Board, 2019). Exceedance of the WQO concentration objectives is measured by calculating a seasonal average concentration of samples collected from April 1 to October 30 and comparing against the WQO; exceedance of the WQO load targets is measured by calculating a 5 -year running average load and comparing against the WQO. In 2019, the IRRB approved these WQOs and submitted them to the IJC. Concerns over nutrient enrichment and continued exceedances of WQOs for sulfate and total dissolved solids raised concerns that water-quality conditions are changing in the basin.

To understand how water-quality conditions have changed in the basin, an up-to-date (2015) integrated basin approach for assessing trends was needed, particularly one that accounts for changes in streamflow conditions. Analysis of water-quality trends has been completed by various agencies for varying periods, constituents, and areas of the basin (Vecchia, 2000; Jones and Armstrong, 2001; Vecchia, 2003; Vecchia, 2005; Paquette, 2011; Galloway and others, 2012). Streamflow conditions reflect climatic variability, which is referred to as hydroclimatic variability. A shift from a dry climate state to a wet climate state around 1980 resulted in an abrupt increase in streamflow in the basin in 1993 (Vecchia, 2008; Kolars and others, 2015; Ryberg and others, 2016). The shift to a wet climate state initially led to increasing soil moisture and surface-water storage, and eventually, when storage was filled, streamflow abruptly increased in the basin (Vecchia, 2008; Kolars and others, 2015; Ryberg and others, 2016). To understand how water-quality conditions are changing, it is imperative to understand how the more recent (1993-2019) state of high moisture storage throughout the basin and larger contributions of groundwater and surface runoff affect constituent transport and concentrations. The current study describes results of the U.S. Geological Survey (USGS) comprehensive trend analysis completed in cooperation with 


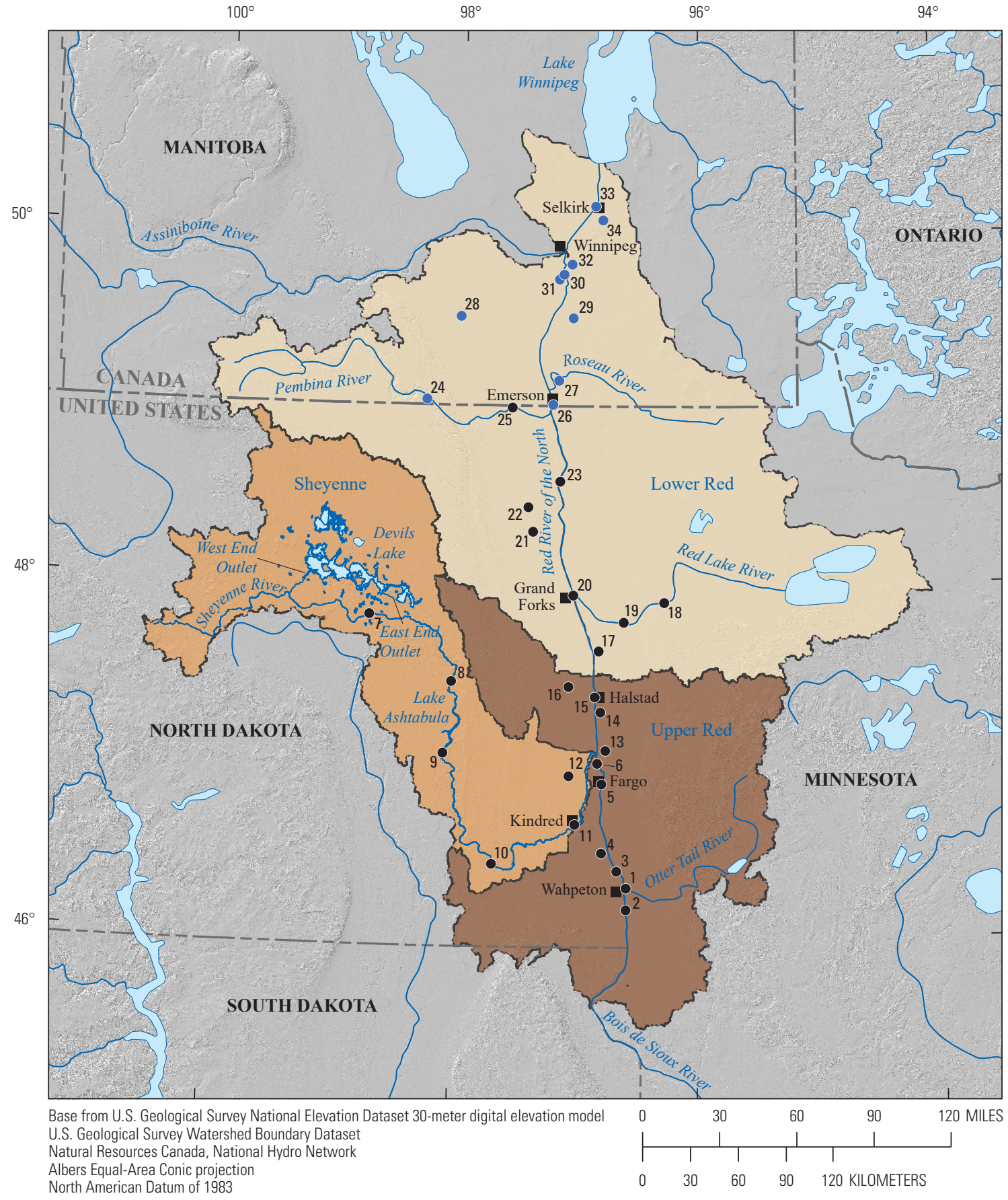

EXPLANATION

Subbasins

Water-quality site and number (table 1)

Lower Red

24. Canada

Sheyenne

${ }^{25}$ - United States

Upper Red

Figure 1. Location of study area and sampling sites in the Red River of the North Basin, Minnesota, North Dakota, and Manitoba, Canada. 
the IJC, North Dakota Department of Environmental Quality (NDDEQ), and Minnesota Pollution Control Agency (MPCA) and in collaboration with Manitoba Sustainable Development (MSD) and Environment and Climate Change Canada (ECCC), which considers natural hydroclimatic variability and assesses exceedances of the WQOs in the Red River at Emerson.

\section{Purpose and Scope}

This report describes the methods and results of a comparison of trends in concentration for selected water-quality constituents in the Red River of the North Basin at selected sites in the United States and Canada for two periods, 2000-15 and 1970-2015. Additionally, a detailed evaluation of waterquality conditions for constituents with an established or proposed WQO, including probability of exceedances of WQOs, at the binational site is presented (fig. 1, site 26). Water-quality data from State, Provincial, and Federal agencies in the United States and Canada for sites in the basin from 1970 to 2017 were compiled. A total of 34 sites were evaluated for waterquality trends in concentrations of sulfate, chloride, total dissolved solids, nitrate plus nitrite as nitrogen (hereafter referred to as "nitrate plus nitrite"), total nitrogen, total phosphorus, and total suspended solids during 2000-15 (hereafter referred to as the "recent period"). Of the 34 sites, the binational site (site 26) and 8 other sites were on the main stem of the Red River, and 25 were on tributaries (fig. 1). Although seven water-quality constituents were evaluated for trends during the recent period, not all sites had enough data for all constituents to be analyzed. For 5 of the 34 sites, trends in concentrations of sulfate, total dissolved solids, nitrate plus nitrite, and total phosphorus were evaluated during 1970-2015, hereafter referred to as the "historical period." For the binational site (site 26), historical trends, annual loads, and probability of exceeding the WQO for sulfate, chloride, total dissolved solids, total nitrogen, and total phosphorus were analyzed.

The trend-analysis approach used in the current (2020) study removes natural or hydroclimatically induced variability in constituent concentration because of interannual variability in streamflow. As such, trends are assumed to be related to drivers other than natural hydroclimatic variability, such as fertilizer application, land-use change, changes in agricultural practices, livestock production, and urban or industrial development. Potential factors affecting observed trends are discussed, but a full interpretation of the causation of trends is beyond the scope of the current study.

\section{Description of Study Area}

The basin lies within 2 countries, 3 States, and 1 Province (fig. 1) and drains 45,000 square miles, beginning at the confluence of the Bois de Sioux River and the Otter Tail River in Wahpeton, North Dakota (International Joint Commission, 2019). The Red River flows north through the larger cities of Fargo, N. Dak.; Grand Forks, N. Dak.; and Winnipeg, Manitoba, before emptying into Lake Winnipeg (fig. 1). Land use in the basin is primarily agriculture (Stoner and others, 1993; Tornes, 2005) with about 72 percent of the basin in agricultural production (Ryberg and others, 2016). Primary crops are wheat, corn, soybeans, and sugar beets. The basin's physiography, geology, soils, and climate are described in Stoner and others (1993).

Streamflow in the basin is highly variable on seasonal, annual, and multidecadal scales. On a seasonal scale, the highest streamflows occur in late March or early April because of snowmelt or rainfall on snow or partially frozen soils (Vecchia, 2003, 2005). During April through September, streamflow recedes as snowmelt runoff diminishes and net evaporation increases. Streamflow during September through February is low and dominated by base flow from groundwater or reservoir discharge. Interannually, streamflow can vary by one-tenth of normal to more than 10 times normal (Vecchia, 2003). As an example of the interannual variability, annual mean streamflow in 2011 for the Red River at Grand Forks, N. Dak. (site 20), was 14,300 cubic feet per second ( $\left.\mathrm{ft}^{3} / \mathrm{s}\right)$, and the following year (2012), the annual mean streamflow was $2,900 \mathrm{ft}^{3} / \mathrm{s}$ (U.S. Geological Survey, 2019). Additionally, large floods tend to cluster together. Five of the largest floods on record for the Red River at Grand Forks, N. Dak. (site 20), have occurred between 1997 and 2019 (U.S. Geological Survey, 2019). On a multidecadal scale, a wet climate state began in the 1980s, which resulted in an abrupt increase in streamflow in 1993 and has persisted to the present (2020; Vecchia, 2003, 2008; Kolars and others, 2015; Ryberg and others, 2016). Changes in the amount and timing of runoff from year to year can have a large effect on the relative amount of natural and anthropogenic sources of dissolved ions and nutrients that are transported to streams, which in turn, can result in large year-to-year changes in concentrations and loads. Removing year-to-year variability because of changing streamflow conditions makes trends caused by other factors, such as changes in agricultural or urban land use, easier to detect and interpret.

\section{Methods}

Water-quality data for sites in the United States were obtained from the National Water Quality Monitoring Council Water Quality Portal (WQP; National Water Quality Monitoring Council, 2019), and streamflow data for U.S. sites were obtained from the USGS National Water Information System database (U.S. Geological Survey, 2019). MSD supplied water-quality data for 8 of the 10 Canadian sites, ECCC provided water-quality data for the binational site and the Canadian site on the Pembina River, and streamflow for Canadian sites was provided by Water Survey of Canada 
(WSC; Nustad, 2020). Data generated (or analyzed) during the current study are available as a USGS data release (Nustad, 2020).

\section{Site and Constituent Selection}

Sites were chosen based on data availability, and constituents were selected based on established or proposed WQOs and importance in understanding nutrient water-quality conditions in the basin. Initially, 34 sites (including 24 U.S. and 10 Canadian sites) were identified to have data available at least since 2003 (rows highlighted in gray in table 1) and were given a site location number ordered from upstream (1) to downstream (34). Multiple U.S. agencies collect waterquality data at the same site location but use different formats to identify sites; therefore, the WQP was queried for any site within 5 miles of the latitude and longitude of each of the 24 U.S. site locations. A total of 58 site identifiers with waterquality data collected by 4 agencies, MPCA, USGS, NDDEQ, and Minnesota Department of Agriculture, were identified (table 1). Streamflow data for U.S. sites were from USGS streamgages (U.S. Geological Survey, 2019), and streamflow data for Canadian sites were provided either by ECCC or MSD (Nustad, 2020). Sulfate, chloride, total dissolved solids, total nitrogen, and total phosphorus were selected for analysis because WQOs were established (Gabriel and Benoy, 2016) or proposed (International Red River Board, 2011). Although WQOs are not established for nitrate plus nitrite and total suspended solids, these constituents were considered important because they provide additional information about nutrient water-quality conditions.

\section{Water-Quality Data Compilation}

Water-quality data compiled for the current study are from multiple agencies using multiple analysis methods, collected over differing periods. Water-quality data compiled from multiple agencies introduces the potential for inconsistencies between data for the same constituent. Consistent fieldcollection and laboratory-analytical methods are important in trend analysis to be confident that observed trends represent real environmental changes and not inconsistencies in collection and analytical methods (Sando and others, 2014a). Therefore, metadata describing the collecting agencies, analyzing entities, parts of sample analyzed (total or dissolved), analysis types (calculated or actual), reporting units, and analysis methods were considered during data compilation. If significant step trends caused by method or collection differences were detected during trend analysis, step trends were applied to ensure trends represented real environmental changes (discussed in the "Trend Analysis" section).

For U.S. sites, 111,197 results for sulfate, chloride, total dissolved solids, total suspended solids, and nutrients were retrieved from the WQP for 58 site identifiers (table 1) from January 1, 1970, to December 31, 2017. The WQP metadata fields associated with sample results were used to identify constituents of interest and comparability of constituents among agencies. The metadata field in WQP, "CharacteristicName," identified the constituent of interest, and the metadata field "ResultSampleFractionText" identified the part of the sample used for analysis. For sulfate, chloride, total dissolved solids, and total suspended solids, the same CharacteristicName was used by each agency for each constituent, and three unique categories of ResultSampleFractionText were identified, "total," "dissolved," and "suspended." Categories of "total" and "dissolved" were associated with sulfate, chloride, and total dissolved solids, and "suspended" was associated with total suspended solids. Identifying comparable nutrients was more complicated because the CharacteristicName field contained several broad categories, and depending on the agency, results for the same constituent were stored in more than one CharacteristicName field. For example, NDDEQ stored total phosphorus results as CharacteristicName "Phosphatephosphorus," but MPCA stored total phosphorus results as CharacteristicName "Phosphorus." For nutrients, eight categories of the CharacteristicName field were used for total nitrogen, total phosphorus, and nitrate plus nitrite. For nutrients, three unique categories of ResultSampleFractionText field were identified, "total," "dissolved," and "supernate." For nutrients, "total" can represent multiple species (for example, total nitrogen) or refer to an unfiltered sample (Oelsner and others, 2017). After discussion with the data-collecting agencies, it was determined that "total" in the ResultSampleFractionText field referred to results from an unfiltered sample and "dissolved" referred to results from a filtered sample. The "supernate" category was used only by NDDEQ as described in the following paragraph.

For constituents that occur primarily in dissolved form (sulfate, chloride, and nitrate plus nitrite), results from unfiltered and filtered samples were combined. Most results for these constituents were for a filtered sample, but results from unfiltered samples were used to supplement the dataset when the filtered result was not available. Sample results for unfiltered samples were used for total phosphorus and total nitrogen. The NDDEQ laboratory identified some total phosphorus and total nitrogen samples as "supernate" under the ResultSampleFractionText field. These samples were sent to the laboratory as an unfiltered sample and, as such, were initially grouped with "total." The "supernate" designation refers to the part of the sample that is drawn from the sample for analysis. The standard procedure for samples with a "supernate" designation was for the analyst to let the sample rest for a short period of time then draw off an aliquot of liquid from the top of the sample above the precipitate or sediment of the sample (supernate) (Todd Ussatis, North Dakota Department of Environmental Quality, written commun., 2019). During trend analysis, "supernate" results were determined to be biased low compared to other laboratory analyses of "total" concentration. This low bias likely was caused by particulates 
Table 1. Sites selected for trend analysis and sources of data in the Red River of the North Basin, Minnesota, North Dakota, and Manitoba, Canada.

[Gray shading indicates sites with data available since at least 2003, and the site identifier and name used to represent site location throughout the report; MNPCA, Minnesota Pollution Control Agency; US, United States; MPCA, Minnesota Pollution Control Agency; USGS, U.S. Geological Survey; MN, Minnesota; --, no data or not applicable; NDDEQ, North Dakota Department of Environmental Quality; R, River; CSAH, county state aid highway; mi, miles; SW, southwest; MNDA, Minnesota Department of Agriculture; BR, bridge; W, west; nr, near; ND, North Dakota; Ave, Avenue; St., street; no., number; Brg, Bridge; ID, identifier; CR, County Road; N, north; SE, southeast; S, south; E, east; bl, below; US-75, U.S. Highway 75; Lk, Lake; btw, between; Fks, Forks; MN-11, Minnesota Highway 11; Hwy, Highway; MB, Manitoba; CA, Canada; ECCC, Environment and Climate Change Canada; MSD, Manitoba Sustainable Development; WSC, Water Survey of Canada]

\begin{tabular}{|c|c|c|c|c|c|c|c|c|c|}
\hline $\begin{array}{l}\text { Site location } \\
\text { (fig. 1) }\end{array}$ & $\begin{array}{c}\text { Site } \\
\text { identifier1 }\end{array}$ & $\begin{array}{l}\text { Site } \\
\text { name }\end{array}$ & $\begin{array}{c}\text { Site number } \\
\text { for streamflow } \\
\text { data }^{2}\end{array}$ & $\begin{array}{l}\text { Site } \\
\text { type }\end{array}$ & Country & $\begin{array}{l}\text { Collecting } \\
\text { agency } \\
\text { for water- } \\
\text { quality data }\end{array}$ & $\begin{array}{l}\text { Latitude, } \\
\text { decimal } \\
\text { degrees }\end{array}$ & $\begin{array}{l}\text { Longitude, } \\
\text { decimal } \\
\text { degrees }\end{array}$ & $\begin{array}{l}\text { Collecting } \\
\text { agency for } \\
\text { streamflow } \\
\text { data }\end{array}$ \\
\hline 1 & MNPCA-S002-000 & $\begin{array}{l}\text { OTTER TAIL R AT 11TH } \\
\text { STREET BRIDGE IN } \\
\text { BRECKENRIDGE }\end{array}$ & 05046475 & Tributary & US & MPCA & 46.274485 & -96.579919 & USGS \\
\hline 2 & USGS-05051300 & $\begin{array}{l}\text { BOIS DE SIOUX RIVER } \\
\text { NEAR DORAN, MN }\end{array}$ & 05051300 & Tributary & US & USGS & 46.15211 & -96.57953 & USGS \\
\hline 2 & $\begin{array}{l}\text { 21NDHDWQ_WQX- } \\
\quad 385055\end{array}$ & $\begin{array}{l}\text { BOIS DE SIOUX WEST } \\
\text { OF DORAN, MN }\end{array}$ & -- & -- & US & NDDEQ & 46.15211 & -96.57953 & -- \\
\hline 2 & MNPCA-S000-553 & $\begin{array}{l}\text { BOIS DE SIOUX R ON } \\
\text { CSAH-6 5.1 MI SW OF } \\
\text { DORAN }\end{array}$ & -- & -- & US & MPCA & 46.152335 & -96.579456 & -- \\
\hline 2 & $\begin{array}{l}\text { MNDA_PESTICIDE- } \\
\text { S000-553 }\end{array}$ & $\begin{array}{l}\text { BOIS DE SIOUX R ON } \\
\text { CSAH-6 5.1 MI SW OF } \\
\text { DORAN }\end{array}$ & -- & -- & US & MNDA & 46.15211 & -96.57953 & -- \\
\hline 3 & MNPCA-S000-012 & $\begin{array}{l}\text { RED RIVER AT BR ON } \\
\text { CSAH-18 0.5 MI W OF } \\
\text { BRUSHVALE }\end{array}$ & 05051500 & Main stem & US & MPCA & 46.36948 & -96.65682 & USGS \\
\hline 3 & $\begin{array}{l}\text { 21NDHDWQ_WQX- } \\
380083\end{array}$ & $\begin{array}{l}\text { RED RIVER AT } \\
\text { BRUSHVILLE, MN }\end{array}$ & -- & -- & US & NDDEQ & 46.36948 & -96.65682 & -- \\
\hline 4 & USGS-05053000 & $\begin{array}{l}\text { WILD RICE RIVER NR } \\
\text { ABERCROMBIE, ND }\end{array}$ & 05053000 & Tributary & US & USGS & 46.47112 & -96.78198 & USGS \\
\hline 4 & $\begin{array}{l}\text { 21NDHDWQ_WQX- } \\
\quad 380031\end{array}$ & $\begin{array}{l}\text { WILD RICE RIVER } \\
\text { NEAR } \\
\text { ABERCROMBIE }\end{array}$ & -- & -- & US & NDDEQ & 46.47112 & -96.78198 & -- \\
\hline 5 & USGS- 05054000 & $\begin{array}{l}\text { RED RIVER OF THE } \\
\text { NORTH AT FARGO, } \\
\text { ND }\end{array}$ & 05054000 & Main stem & US & USGS & 46.861075 & -96.7836924 & USGS \\
\hline 5 & MNPCA-S000-183 & $\begin{array}{l}\text { RED RIVER BR ON } \\
\text { MAIN AVE AT 3RD } \\
\text { ST., IN MOORHEAD }\end{array}$ & -- & -- & US & MPCA & 46.861075 & -96.7836924 & -- \\
\hline
\end{tabular}


Table 1. Sites selected for trend analysis and sources of data in the Red River of the North Basin, Minnesota, North Dakota, and Manitoba, Canada.-Continued

[Gray shading indicates sites with data available since at least 2003, and the site identifier and name used to represent site location throughout the report; MNPCA, Minnesota Pollution Control Agency; US, United States; MPCA, Minnesota Pollution Control Agency; USGS, U.S. Geological Survey; MN, Minnesota; --, no data or not applicable; NDDEQ, North Dakota Department of Environmental Quality; R, River; CSAH, county state aid highway; mi, miles; SW, southwest; MNDA, Minnesota Department of Agriculture; BR, bridge; W, west; nr, near; ND, North Dakota; Ave, Avenue; St., street; no., number; Brg, Bridge; ID, identifier; CR, County Road; N, north; SE, southeast; S, south; E, east; bl, below; US-75, U.S. Highway 75; Lk, Lake; btw, between; Fks, Forks; MN-11, Minnesota Highway 11; Hwy, Highway; MB, Manitoba; CA, Canada; ECCC, Environment and Climate Change Canada; MSD, Manitoba Sustainable Development; WSC, Water Survey of Canada]

\begin{tabular}{|c|c|c|c|c|c|c|c|c|c|}
\hline $\begin{array}{l}\text { Site location } \\
\text { (fig. 1) }\end{array}$ & $\begin{array}{c}\text { Site } \\
\text { identifier }^{1}\end{array}$ & $\begin{array}{c}\text { Site } \\
\text { name }\end{array}$ & $\begin{array}{c}\text { Site number } \\
\text { for streamflow } \\
\text { data }^{2}\end{array}$ & $\begin{array}{l}\text { Site } \\
\text { type }\end{array}$ & Country & $\begin{array}{l}\text { Collecting } \\
\text { agency } \\
\text { for water- } \\
\text { quality data }\end{array}$ & $\begin{array}{l}\text { Latitude, } \\
\text { decimal } \\
\text { degrees }\end{array}$ & $\begin{array}{l}\text { Longitude, } \\
\text { decimal } \\
\text { degrees }\end{array}$ & $\begin{array}{l}\text { Collecting } \\
\text { agency for } \\
\text { streamflow } \\
\text { data }\end{array}$ \\
\hline 5 & MNPCA-S002-116 & $\begin{array}{l}\text { RED R ON FIRST AVE } \\
\text { NO. BRG IN MOOR- } \\
\text { HEAD, MN/FARGO, } \\
\text { ND }\end{array}$ & -- & -- & US & MPCA & 46.861075 & -96.7836924 & -- \\
\hline 6 & USGS-05054200 & $\begin{array}{l}\text { RED RIVER OF THE } \\
\text { NORTH NEAR } \\
\text { HARWOOD, ND }\end{array}$ & 05054000 & Main stem & US & USGS & 46.976761 & -96.820069 & USGS \\
\hline 6 & $\begin{array}{l}\text { 21NDHDWQ_WQX- } \\
385040\end{array}$ & $\begin{array}{l}\text { RED RIVER NEAR } \\
\text { HARWOOD }\end{array}$ & -- & -- & US & NDDEQ & 46.97695 & -96.82026 & -- \\
\hline 6 & $\begin{array}{l}\text { 21NDHDWQ_WQX- } \\
386015\end{array}$ & $\begin{array}{l}\text { RED RIVER ON CASS } \\
\text { 22 RIVER KEEPER ID } \\
\text { 3RR SAMPLE TAKEN } \\
\text { OFF OF BRIDGE }\end{array}$ & -- & -- & US & NDDEQ & 46.976761 & -96.820069 & -- \\
\hline 6 & MNPCA-S002-097 & $\begin{array}{l}\text { RED RIVER OF THE } \\
\text { NORTH AT CR-26, } \\
7 \text { MI N OF FARGO/ } \\
\text { MOORHEAD }\end{array}$ & -- & -- & US & MPCA & 46.976761 & -96.820069 & -- \\
\hline 7 & USGS-05056000 & $\begin{array}{l}\text { SHEYENNE RIVER NR } \\
\text { WARWICK, ND }\end{array}$ & 05056000 & Tributary & US & USGS & 47.80526 & -98.71717 & USGS \\
\hline 7 & $\begin{array}{l}\text { 21NDHDWQ_WQX- } \\
385345\end{array}$ & $\begin{array}{l}\text { SHEYENNE RIVER } \\
\text { NEAR WARWICK }\end{array}$ & -- & -- & US & NDDEQ & 47.80526 & -98.71717 & -- \\
\hline 8 & USGS-05057000 & $\begin{array}{l}\text { SHEYENNE RIVER NR } \\
\text { COOPERSTOWN, ND }\end{array}$ & 05057000 & Tributary & US & USGS & 47.43292 & -98.02784 & USGS \\
\hline 8 & $\begin{array}{l}\text { 21NDHDWQ_WQX- } \\
380009\end{array}$ & $\begin{array}{l}\text { SHEYENNE RIVER NR } \\
\text { COOPERSTOWN }\end{array}$ & -- & -- & US & NDDEQ & 47.43292 & -98.02784 & -- \\
\hline 9 & USGS-05058000 & $\begin{array}{l}\text { SHEYENNE RIVER } \\
\text { BELOW BALDHILL } \\
\text { DAM, ND }\end{array}$ & 05058000 & Tributary & US & USGS & 47.02735 & -98.08619 & USGS \\
\hline 9 & $\begin{array}{l}\text { 21NDHDWQ_WQX- } \\
380153\end{array}$ & $\begin{array}{l}\text { SHEYENNE RIVER BE- } \\
\text { LOW BALDHILL DAM }\end{array}$ & -- & -- & US & NDDEQ & 47.02735 & -98.08619 & -- \\
\hline
\end{tabular}


Table 1. Sites selected for trend analysis and sources of data in the Red River of the North Basin, Minnesota, North Dakota, and Manitoba, Canada.-Continued

[Gray shading indicates sites with data available since at least 2003, and the site identifier and name used to represent site location throughout the report; MNPCA, Minnesota Pollution Control Agency; US, United States; MPCA, Minnesota Pollution Control Agency; USGS, U.S. Geological Survey; MN, Minnesota; --, no data or not applicable; NDDEQ, North Dakota Department of Environmental Quality; R, River; CSAH, county state aid highway; mi, miles; SW, southwest; MNDA, Minnesota Department of Agriculture; BR, bridge; W, west; nr, near; ND, North Dakota; Ave, Avenue; St., street; no., number; Brg, Bridge; ID, identifier; CR, County Road; N, north; SE, southeast; S, south; E, east; bl, below; US-75, U.S. Highway 75; Lk, Lake; btw, between; Fks, Forks; MN-11, Minnesota Highway 11; Hwy, Highway; MB, Manitoba; CA, Canada; ECCC, Environment and Climate Change Canada; MSD, Manitoba Sustainable Development; WSC, Water Survey of Canada]

\begin{tabular}{|c|c|c|c|c|c|c|c|c|c|}
\hline $\begin{array}{l}\text { Site location } \\
\text { (fig. 1) }\end{array}$ & $\begin{array}{c}\text { Site } \\
\text { identifier1 }\end{array}$ & $\begin{array}{c}\text { Site } \\
\text { name }\end{array}$ & $\begin{array}{c}\text { Site number } \\
\text { for streamflow } \\
\text { data }^{2}\end{array}$ & $\begin{array}{l}\text { Site } \\
\text { type }\end{array}$ & Country & $\begin{array}{l}\text { Collecting } \\
\text { agency } \\
\text { for water- } \\
\text { quality data }\end{array}$ & $\begin{array}{l}\text { Latitude, } \\
\text { decimal } \\
\text { degrees }\end{array}$ & $\begin{array}{l}\text { Longitude, } \\
\text { decimal } \\
\text { degrees }\end{array}$ & $\begin{array}{l}\text { Collecting } \\
\text { agency for } \\
\text { streamflow } \\
\text { data }\end{array}$ \\
\hline 10 & USGS-05058700 & $\begin{array}{l}\text { SHEYENNE RIVER AT } \\
\text { LISBON, ND }\end{array}$ & 05058700 & Tributary & US & USGS & 46.40567 & -97.67297 & USGS \\
\hline 10 & $\begin{array}{l}\text { 21NDHDWQ_WQX- } \\
380007\end{array}$ & $\begin{array}{l}\text { SHEYENNE RIVER IN } \\
\text { LISBON ND HIWAY } 27 \\
\text { BRIDGE }\end{array}$ & -- & -- & US & NDDEQ & 46.40567 & -97.67297 & -- \\
\hline 10 & $\begin{array}{l}\text { 21NDHDWQ_WQX- } \\
\quad 385168\end{array}$ & $\begin{array}{l}\text { SHEYENNE RIVER NR } \\
\text { LISBON }\end{array}$ & -- & -- & US & NDDEQ & 46.40567 & -97.67297 & -- \\
\hline 11 & USGS-05059000 & $\begin{array}{l}\text { SHEYENNE RIVER } \\
\text { NEAR KINDRED }\end{array}$ & 05059000 & Tributary & US & USGS & 46.63146 & -97.0003 & USGS \\
\hline 11 & $\begin{array}{l}\text { 21NDHDWQ_WQX- } \\
385001\end{array}$ & $\begin{array}{l}\text { SHEYENNE RIVER SE } \\
\text { OF KINDRED } 1 \mathrm{MI} \text { S, } \\
2.5 \text { MI E OF KINDRED } \\
.25 \mathrm{MI} \text { N ON } 167 \mathrm{TH} \\
\text { AVE SE }\end{array}$ & -- & -- & US & NDDEQ & 46.63146 & -97.0003 & -- \\
\hline 12 & USGS-05060100 & $\begin{array}{l}\text { MAPLE RIVER BL } \\
\text { MAPLETON, ND }\end{array}$ & 05060100 & Tributary & US & USGS & 46.9054 & -97.05251 & USGS \\
\hline 12 & $\begin{array}{l}\text { 21NDHDWQ_WQX- } \\
\quad 384155\end{array}$ & $\begin{array}{l}\text { MAPLE RIVER AT } \\
\text { MAPLETON }\end{array}$ & -- & -- & US & NDDEQ & 46.9054 & -97.05251 & -- \\
\hline 13 & MNPCA-S002-125 & $\begin{array}{l}\text { BUFFALO R AT CR-108, } \\
2 \text { MI SE OF } \\
\text { GEORGETOWN }\end{array}$ & 05062000 & Tributary & US & MPCA & 47.04978 & -96.753688 & USGS \\
\hline 13 & $\begin{array}{l}\text { MNDA_PESTICIDE- } \\
\text { S002-125 }\end{array}$ & $\begin{array}{l}\text { BUFFALO R AT CR-108, } \\
2 \text { MI SE OF } \\
\text { GEORGETOWN }\end{array}$ & -- & -- & US & MNDA & 47.04978 & -96.753688 & -- \\
\hline 14 & USGS-05064000 & $\begin{array}{l}\text { WILD RICE RIVER AT } \\
\text { HENDRUM, MN }\end{array}$ & 05064000 & Tributary & US & USGS & 47.266713 & -96.796894 & USGS \\
\hline 14 & MNPCA-S002-102 & $\begin{array}{l}\text { WILD RICE R AT CR-25, } \\
0.8 \text { MI E OF } \\
\text { HENDRUM }\end{array}$ & -- & -- & US & MPCA & 47.266713 & -96.796894 & -- \\
\hline
\end{tabular}


Table 1. Sites selected for trend analysis and sources of data in the Red River of the North Basin, Minnesota, North Dakota, and Manitoba, Canada.-Continued

[Gray shading indicates sites with data available since at least 2003, and the site identifier and name used to represent site location throughout the report; MNPCA, Minnesota Pollution Control Agency; US, United States; MPCA, Minnesota Pollution Control Agency; USGS, U.S. Geological Survey; MN, Minnesota; --, no data or not applicable; NDDEQ, North Dakota Department of Environmental Quality; R, River; CSAH, county state aid highway; mi, miles; SW, southwest; MNDA, Minnesota Department of Agriculture; BR, bridge; W, west; nr, near; ND, North Dakota; Ave, Avenue; St., street; no., number; Brg, Bridge; ID, identifier; CR, County Road; N, north; SE, southeast; S, south; E, east; bl, below; US-75, U.S. Highway 75; Lk, Lake; btw, between; Fks, Forks; MN-11, Minnesota Highway 11; Hwy, Highway; MB, Manitoba; CA, Canada; ECCC, Environment and Climate Change Canada; MSD, Manitoba Sustainable Development; WSC, Water Survey of Canada]

\begin{tabular}{|c|c|c|c|c|c|c|c|c|c|}
\hline $\begin{array}{l}\text { Site location } \\
\quad \text { (fig. 1) }\end{array}$ & $\begin{array}{c}\text { Site } \\
\text { identifier } 1\end{array}$ & $\begin{array}{l}\text { Site } \\
\text { name }\end{array}$ & $\begin{array}{c}\text { Site number } \\
\text { for streamflow } \\
\text { data }^{2}\end{array}$ & $\begin{array}{l}\text { Site } \\
\text { type }\end{array}$ & Country & $\begin{array}{l}\text { Collecting } \\
\text { agency } \\
\text { for water- } \\
\text { quality data }\end{array}$ & $\begin{array}{l}\text { Latitude, } \\
\text { decimal } \\
\text { degrees }\end{array}$ & $\begin{array}{l}\text { Longitude, } \\
\text { decimal } \\
\text { degrees }\end{array}$ & $\begin{array}{l}\text { Collecting } \\
\text { agency for } \\
\text { streamflow } \\
\text { data }\end{array}$ \\
\hline 14 & $\begin{array}{l}\text { MNDA_PESTICIDE- } \\
\text { S002-102 }\end{array}$ & $\begin{array}{l}\text { WILD RICE R AT CR-25, } \\
\text { 0.8 MI E OF } \\
\text { HENDRUM }\end{array}$ & -- & -- & US & MNDA & 47.266713 & -96.796894 & -- \\
\hline 15 & USGS-05064500 & $\begin{array}{l}\text { RED RIVER OF THE } \\
\text { NORTH AT HALSTAD, } \\
\text { ND }\end{array}$ & 05064500 & Main stem & US & USGS & 47.351918 & -96.843691 & USGS \\
\hline 15 & MNPCA-S000-092 & $\begin{array}{l}\text { RED RIVER BRIDGE ON } \\
\text { MN-200, 0.5 MI W OF } \\
\text { HALSTAD }\end{array}$ & -- & -- & US & MPCA & 47.351918 & -96.843691 & -- \\
\hline 15 & MNPCA-S000-113 & $\begin{array}{l}\text { RED RIVER AT BRIDGE } \\
\text { ON CSAH-39, } 1 \text { MI W } \\
\text { OF PERLEY }\end{array}$ & -- & -- & US & MPCA & 47.351918 & -96.843691 & -- \\
\hline 16 & USGS-05066500 & $\begin{array}{l}\text { GOOSE RIVER AT } \\
\text { HILLSBORO, ND }\end{array}$ & 05066500 & Tributary & US & USGS & 47.40942385 & -97.0611974 & USGS \\
\hline 16 & $\begin{array}{l}\text { 21NDHDWQ_WQX- } \\
\quad 380156\end{array}$ & $\begin{array}{l}\text { GOOSE RIVER AT } \\
\text { HILLSBORO IN } \\
\text { HILLSBORO } 27.5 \mathrm{MI} \\
\text { UPSTREAM FROM } \\
\text { MOUTH USGS } \\
\text { COLLOCATED }\end{array}$ & -- & -- & US & NDDEQ & 47.40942385 & -97.0611974 & -- \\
\hline 17 & MNPCA-S002-099 & $\begin{array}{l}\text { SAND HILL R AT US-75 } \\
\text { ON NORTH END OF } \\
\text { CLIMAX }\end{array}$ & 05069000 & Tributary & US & MPCA & 47.612055 & -96.814755 & USGS \\
\hline 17 & $\begin{array}{l}\text { MNDA_PESTICIDE- } \\
\text { S002-099 }\end{array}$ & $\begin{array}{l}\text { SAND HILL R AT US-75 } \\
\text { ON NORTH END OF } \\
\text { CLIMAX }\end{array}$ & -- & -- & US & MNDA & 47.612055 & -96.814755 & -- \\
\hline 18 & MNPCA-S002-118 & $\begin{array}{l}\text { CLEARWATER R AT } \\
\text { KLONDIKE BRIDGE/ } \\
\text { BOTTINEAU AVE } \\
\text { RED LAKE FALLS }\end{array}$ & 05078500 & Tributary & US & MPCA & 47.88808 & -96.27454 & USGS \\
\hline 19 & USGS-05079000 & $\begin{array}{l}\text { RED LAKE RIVER AT } \\
\text { CROOKSTON, MN }\end{array}$ & 05079000 & Tributary & US & USGS & 47.775556 & -96.609167 & USGS \\
\hline
\end{tabular}


Table 1. Sites selected for trend analysis and sources of data in the Red River of the North Basin, Minnesota, North Dakota, and Manitoba, Canada.-Continued

[Gray shading indicates sites with data available since at least 2003, and the site identifier and name used to represent site location throughout the report; MNPCA, Minnesota Pollution Control Agency; US, United States; MPCA, Minnesota Pollution Control Agency; USGS, U.S. Geological Survey; MN, Minnesota; --, no data or not applicable; NDDEQ, North Dakota Department of Environmental Quality; R, River; CSAH, county state aid highway; mi, miles; SW, southwest; MNDA, Minnesota Department of Agriculture; BR, bridge; W, west; nr, near; ND, North Dakota; Ave, Avenue; St., street; no., number; Brg, Bridge; ID, identifier; CR, County Road; N, north; SE, southeast; S, south; E, east; bl, below; US-75, U.S. Highway 75; Lk, Lake; btw, between; Fks, Forks; MN-11, Minnesota Highway 11; Hwy, Highway; MB, Manitoba; CA, Canada; ECCC, Environment and Climate Change Canada; MSD, Manitoba Sustainable Development; WSC, Water Survey of Canada]

\begin{tabular}{|c|c|c|c|c|c|c|c|c|c|}
\hline $\begin{array}{l}\text { Site location } \\
\text { (fig. 1) }\end{array}$ & $\begin{array}{c}\text { Site } \\
\text { identifier1 }\end{array}$ & $\begin{array}{c}\text { Site } \\
\text { name }\end{array}$ & $\begin{array}{c}\text { Site number } \\
\text { for streamflow } \\
\text { data }^{2}\end{array}$ & $\begin{array}{l}\text { Site } \\
\text { type }\end{array}$ & Country & $\begin{array}{l}\text { Collecting } \\
\text { agency } \\
\text { for water- } \\
\text { quality data }\end{array}$ & $\begin{array}{l}\text { Latitude, } \\
\text { decimal } \\
\text { degrees }\end{array}$ & $\begin{array}{l}\text { Longitude, } \\
\text { decimal } \\
\text { degrees }\end{array}$ & $\begin{array}{l}\text { Collecting } \\
\text { agency for } \\
\text { streamflow } \\
\text { data }\end{array}$ \\
\hline 19 & MNPCA-S002-080 & $\begin{array}{l}\text { RED LK R, SAMPSON } \\
\text { BRG, IN CROOKSTON }\end{array}$ & -- & -- & US & MPCA & 47.775556 & -96.609167 & -- \\
\hline 20 & USGS- 05082500 & $\begin{array}{l}\text { RED RIVER OF THE } \\
\text { NORTH AT GRAND } \\
\text { FORKS, ND }\end{array}$ & 05082500 & Main stem & US & USGS & 47.9269234 & -97.0292435 & USGS \\
\hline 20 & $\begin{array}{l}\text { 21NDHDWQ_WQX- } \\
\quad 384156\end{array}$ & $\begin{array}{l}\text { RED RIVER AT GRAND } \\
\text { FORKS DEMERS AVE } \\
\text { BRIDGE }\end{array}$ & -- & -- & US & NDDEQ & 47.927039 & -97.02878 & -- \\
\hline 20 & MNPCA-S000-008 & $\begin{array}{l}\text { RED RIVER AT GRAND } \\
\text { FORKS }\end{array}$ & -- & -- & US & MPCA & 47.943278 & -97.050139 & -- \\
\hline 20 & MNPCA-S002-113 & $\begin{array}{l}\text { RED R AT DEMERS AVE } \\
\text { BRG BTW E GRAND } \\
\text { FKS, MN \& GRAND } \\
\text { FKS, ND }\end{array}$ & -- & -- & US & MPCA & 47.926891 & -97.028413 & -- \\
\hline 21 & USGS-05085000 & $\begin{array}{l}\text { FOREST RIVER NEAR } \\
\text { MINTO, ND }\end{array}$ & 05085000 & Tributary & US & USGS & 48.286099 & -97.3700763 & USGS \\
\hline 21 & $\begin{array}{l}\text { 21NDHDWQ_WQX- } \\
\quad 380039\end{array}$ & $\begin{array}{l}\text { FOREST RIVER-NR } \\
\text { MINTO }\end{array}$ & -- & -- & US & NDDEQ & 48.286099 & -97.3700763 & -- \\
\hline 22 & USGS-05090000 & $\begin{array}{l}\text { PARK RIVER AT } \\
\text { GRAFTON, ND }\end{array}$ & 05090000 & Tributary & US & USGS & 48.4247108 & -97.412023 & USGS \\
\hline 22 & $\begin{array}{l}\text { 21NDHDWQ_WQX- } \\
380157\end{array}$ & $\begin{array}{l}\text { PARK RIVER AT } \\
\text { GRAFTON }\end{array}$ & -- & -- & US & NDDEQ & 48.4247108 & -97.412023 & -- \\
\hline 23 & USGS-05092000 & $\begin{array}{l}\text { RED RIVER OF THE } \\
\text { NORTH AT } \\
\text { DRAYTON, ND }\end{array}$ & 05092000 & Main stem & US & USGS & 48.572205 & -97.148042 & USGS \\
\hline 23 & $\begin{array}{l}\text { 21NDHDWQ_WQX- } \\
380004\end{array}$ & $\begin{array}{l}\text { RED RIVER-DRAYTON } \\
\text { DOWNSTREAM OF } \\
\text { DRAYTON }\end{array}$ & -- & -- & US & NDDEQ & 48.572205 & -97.148042 & -- \\
\hline 23 & MNPCA-S000-091 & $\begin{array}{l}\text { RED RIVER AT BRIDGE } \\
\text { ON MN-11, WEST OF } \\
\text { ROBBIN }\end{array}$ & -- & -- & US & MPCA & 48.572205 & -97.148042 & -- \\
\hline
\end{tabular}


Table 1. Sites selected for trend analysis and sources of data in the Red River of the North Basin, Minnesota, North Dakota, and Manitoba, Canada.-Continued

[Gray shading indicates sites with data available since at least 2003, and the site identifier and name used to represent site location throughout the report; MNPCA, Minnesota Pollution Control Agency; US, United States; MPCA, Minnesota Pollution Control Agency; USGS, U.S. Geological Survey; MN, Minnesota; --, no data or not applicable; NDDEQ, North Dakota Department of Environmental Quality; R, River; CSAH, county state aid highway; mi, miles; SW, southwest; MNDA, Minnesota Department of Agriculture; BR, bridge; W, west; nr, near; ND, North Dakota; Ave, Avenue; St., street; no., number; Brg, Bridge; ID, identifier; CR, County Road; N, north; SE, southeast; S, south; E, east; bl, below; US-75, U.S. Highway 75; Lk, Lake; btw, between; Fks, Forks; MN-11, Minnesota Highway 11; Hwy, Highway; MB, Manitoba; CA, Canada; ECCC, Environment and Climate Change Canada; MSD, Manitoba Sustainable Development; WSC, Water Survey of Canada]

\begin{tabular}{|c|c|c|c|c|c|c|c|c|c|}
\hline $\begin{array}{l}\text { Site location } \\
\text { (fig. 1) }\end{array}$ & $\begin{array}{c}\text { Site } \\
\text { identifier1 }\end{array}$ & $\begin{array}{l}\text { Site } \\
\text { name }\end{array}$ & $\begin{array}{c}\text { Site number } \\
\text { for streamflow } \\
\text { data }^{2}\end{array}$ & $\begin{array}{l}\text { Site } \\
\text { type }\end{array}$ & Country & $\begin{array}{l}\text { Collecting } \\
\text { agency } \\
\text { for water- } \\
\text { quality data }\end{array}$ & $\begin{array}{l}\text { Latitude, } \\
\text { decimal } \\
\text { degrees }\end{array}$ & $\begin{array}{l}\text { Longitude, } \\
\text { decimal } \\
\text { degrees }\end{array}$ & $\begin{array}{l}\text { Collecting } \\
\text { agency for } \\
\text { streamflow } \\
\text { data }\end{array}$ \\
\hline 24 & MA05OB0001 & $\begin{array}{l}\text { PEMBINA RIVER AT } \\
\text { WINDYGATES, MB }\end{array}$ & 05ОВ007 & Tributary & $\mathrm{CA}$ & $\mathrm{ECCC}$ & 49.03139 & -98.27778 & ECCC \\
\hline 25 & USGS-05100000 & $\begin{array}{l}\text { PEMBINA RIVER AT } \\
\text { NECHE, ND }\end{array}$ & 05100000 & Tributary & US & USGS & 48.9897138 & -97.5570221 & USGS \\
\hline 25 & $\begin{array}{l}\text { 21NDHDWQ_WQX- } \\
\quad 380158\end{array}$ & $\begin{array}{l}\text { PEMBINA RIVER AT } \\
\text { NECHE 0.3 MI E OF } \\
\text { HWY } 18 \text { AT N END OF } \\
\text { NECHE }\end{array}$ & -- & -- & US & NDDEQ & 48.9897138 & -97.5570221 & -- \\
\hline 26 & MA05OC0001 & $\begin{array}{l}\text { RED RIVER AT } \\
\text { EMERSON, MB }\end{array}$ & $05 \mathrm{OC} 001$ & Main stem & $\mathrm{CA}$ & $\mathrm{ECCC}$ & 49.008333 & -97.215 & ECCC \\
\hline 27 & MB05ODS032 & $\begin{array}{l}\text { ROSEAU RIVER AT } \\
\text { DOMINION CITY }\end{array}$ & 05OD001 & Tributary & $\mathrm{CA}$ & MSD & 49.1456 & -97.1675 & WSC \\
\hline 28 & MB05OFS060 & $\begin{array}{l}\text { BOYNE RIVER IN } \\
\text { CARMAN }\end{array}$ & $05 \mathrm{OF} 003$ & Tributary & $\mathrm{CA}$ & MSD & 49.5064 & -98.00361 & WSC \\
\hline 29 & MB05OES026 & $\begin{array}{l}\text { RAT RIVER AT } \\
\text { OTTERBURNE }\end{array}$ & 05OE001 & Tributary & $\mathrm{CA}$ & MSD & 49.5019 & -97.05111 & WSC \\
\hline 30 & MB05OCS004 & $\begin{array}{l}\text { RED RIVER AT SOUTH } \\
\text { GATE OF FLOODWAY }\end{array}$ & $05 \mathrm{OC} 012$ & Main stem & $\mathrm{CA}$ & MSD & 49.7506 & -97.13333 & WSC \\
\hline 31 & MB05OGS039 & $\begin{array}{l}\text { LA SALLE RIVER AT LA } \\
\text { BARRIERE PARK }\end{array}$ & $05 \mathrm{OG} 001$ & Tributary & $\mathrm{CA}$ & MSD & 49.7228 & -97.17139 & WSC \\
\hline 32 & MB05OHS003 & $\begin{array}{l}\text { SEINE RIVER AT SOUTH } \\
\text { PERIMETER HWY }\end{array}$ & 05ОH009 & Tributary & $\mathrm{CA}$ & MSD & 49.8089 & -97.06583 & WSC \\
\hline 33 & MB05OJS074 & $\begin{array}{l}\text { RED RIVER AT } \\
\text { SELKIRK BRIDGE }\end{array}$ & $\begin{array}{l}\text { 05OJ010, } \\
05 \mathrm{OJ} 005\end{array}$ & Main stem & $\mathrm{CA}$ & MSD & 50.1411 & -96.86861 & WSC \\
\hline 34 & MB05OJS006 & $\begin{array}{l}\text { COOKS CREEK AT } \\
\text { BOUNDARY-ST. CLE- } \\
\text { MENTS AND } \\
\text { SPRINGFIELD }\end{array}$ & 05OJ019 & Tributary & CA & MSD & 50.0625 & -96.80611 & WSC \\
\hline
\end{tabular}

${ }^{1}$ For U.S. sites, the site identifier from the National Water Quality Monitoring Council Water Quality Portal is used. For Canadian sites, the site identifier from the collecting agency is used.

${ }^{2}$ For U.S. sites, streamflow sites are colocated with water-quality sites. For Canadian sites, streamflow sites are not always colocated with water-quality sites, and two site numbers indicates two streamflow sites were used to complete the streamflow record for the period of interest. 
in these samples settling out before analysis, resulting in lower concentrations. This low bias was corrected using a step trend as described in the "Trend Analysis" section.

The metadata field, "ResultValueTypeName," identified the analysis type. Two unique analysis types were identified in the data, "actual" and "calculated." Calculated analysis types were associated with total dissolved solids, total Kjeldahl nitrogen (which represents organic and ammonia nitrogen used in calculating total nitrogen), and total nitrogen. Total dissolved solids can be analytically determined or calculated from the sum of major ions. For the current study, results for either analysis type were considered acceptable for total dissolved solids and were combined into one constituent group. Most results for these constituents were analytical values, but calculated values were used to supplement the dataset when the analytical values were not available. Total nitrogen can also be analytically determined or calculated by summing total Kjeldahl nitrogen and nitrate plus nitrite. For most data collected by NDDEQ and USGS, total nitrogen was analytically determined and, if available, calculated values were used to supplement the dataset when the analytical values were not available. For data collected by MPCA and Minnesota Department of Agriculture, total Kjeldahl nitrogen and nitrate plus nitrite were analytically determined. For these samples, a total nitrogen value was calculated as the sum of total Kjeldahl nitrogen and nitrate plus nitrite.

Nutrient results were frequently reported in milligrams per liter with no reference to elemental (milligrams per liter as phosphorus) or molecular (milligrams per liter as phosphate) form. For the current study, "milligrams per liter as nitrogen" for total nitrogen and nitrate plus nitrite and "milligrams per liter as phosphorus" for total phosphorus were used. After discussion with the different agencies, consistent units of elemental nitrogen and phosphorus were selected for use in trend analysis.

Censored values, or values less than the method detection limit but for which an exact value is not known (Oblinger Childress and others, 1999), are an important consideration in trend analysis (Helsel and Hirsch, 2002). Although the software package R-QWTREND estimates censored values, it is recommended there be at most 25-percent censored data to analyze for trends (Vecchia and Nustad, 2020). In the current study, nitrate plus nitrite was the only constituent with sites having more than 25 -percent censored data. A total of 20 sites had more than 25-percent censored data, but to include as many sites as possible in the analysis, sites with as much as 50-percent censored nitrate-plus-nitrite values were analyzed. Of the 20 sites, 2 sites, Red Lake River (site 19) and Maple River (site 12), had more than 50-percent censored data for nitrate plus nitrite and were not analyzed. Because sites were analyzed with more censored data than recommended, the significance level of trends for the 18 sites with more than 25-percent censored data should be interpreted with caution. Also, for U.S. nitrate-plus-nitrite data, there were multiple censoring levels. To compare data and estimate trends for nitrate-plus-nitrite data, the highest censoring level of $0.05 \mathrm{mg} / \mathrm{L}$ was used to recensor nitrate-plus-nitrite data with a lower censoring level to a common censoring level of $0.05 \mathrm{mg} / \mathrm{L}$.

Compilation of water-quality data for Canadian sites was simpler than for U.S. sites because data at each site were collected by a single agency, but there were still data challenges. Water-quality and streamflow data for sites 24 and 26 were provided by ECCC and for sites 27-34, data were provided by MSD (Nustad, 2020). For ECCC water-quality data, total nitrogen was provided as a calculated value of the sum of total dissolved and particulate nitrogen. For MSD, total Kjeldahl nitrogen and nitrate-plus-nitrite data were provided and, thus total nitrogen was calculated by summing the two values. As was done for U.S. nitrate-plus-nitrite data, for both Canadian agencies, all censored nitrate-plus-nitrite data were recensored to a common censoring level of $0.05 \mathrm{mg} / \mathrm{L}$. For MSD sulfate and chloride data, because there were alternating periods of filtered and unfiltered results, both filtered and unfiltered sample results were combined into one dataset. For MSD total phosphorus results, a laboratory-analytical method change was previously identified to cause a high bias of total phosphorus results during April 2001 to March 2009. Also, for ECCC total nitrogen results, a laboratory-analytical method change for total nitrogen on October 1, 1993, was identified to cause a low bias in total nitrogen results. These method changes were addressed by testing for and applying statistically significant step trends as described in the "Trend Analysis" section. For MSD sites 27-29, 31-32, and 34, seasonal streamflow data from sites at or near the sampling site were available. For these sites, estimated monthly flows for missing months were provided by WSC and the estimated monthly value was then assigned to the 15th day of the month and linearly interpolated between values to calculate the daily streamflow value required for R-QWTREND (Nustad, 2020). For sites 27, 29, 32, and 34, streamflow data were only available through 2016.

\section{Trend Analysis}

R-QWTREND, a publicly available software package developed by USGS for analyzing trends in stream water quality, was used in the current study to evaluate waterquality trends (Vecchia and Nustad, 2020). The basis of RQWTREND is a statistical parametric time-series model for streamflow and constituent concentrations (previously referred to as "QWTREND"). The theory and parameter estimation for the time-series model are described in detail in several publications (Vecchia, 2000, 2003, 2005; Vecchia and Nustad, 2020). Earlier applications of the time-series model in the Red River Basin include Jones and Armstrong (2001), Vecchia (2003), Vecchia (2005), and Galloway and others (2012), and applications across the United States include Risch and others (2014), Sando and others (2014a), Sando and others (2014b), and Sando and others (2015). R-QWTREND houses the 
time-series model, fits and verifies trend models, and produces output for interpreting and evaluating trend results (Vecchia and Nustad, 2020).

In R-QWTREND, the time-series model variable, FRVAR is designed to capture as much natural flow-related variability in logarithmically transformed concentrations as possible and is a function of specially crafted variables, called flow anomalies which depend on concurrent and antecedent streamflow (Vecchia and Nustad, 2020). Flow anomalies address the relation between a constituent concentration and concurrent and lagged streamflow at annual, seasonal, and daily time scales. In addition, the periodic functions of sine and cosine are included to model seasonal variation that is not captured by flow anomalies. With the variable climate and corresponding streamflow variability in the basin, characterizing flow-related variability at multiple time scales is important because concentrations of many water-quality constituents may depend on streamflow in complex ways that cannot be accounted for by using a regression model relating concentration only with concurrent streamflow. Accounting for as much natural flow-related variability as possible increases the ability to detect concentration trends independent of trends in streamflow arising from long- and short-term climatic variation (Vecchia, 2003).

Trends detected by R-QWTREND indicate long-term (generally 10 or more years) changes in annual "flowaveraged" geometric mean concentration (FAGMC) that are unrelated to year-to-year changes in streamflow (FAGMC is equivalent to TRGMC in eq. 24 of Vecchia and Nustad, 2020). The annual geometric mean is a useful statistic to compare overall water-quality conditions at a specified sampling location against an aquatic benchmark or in relation to other sampling locations. The annual geometric mean concentration (GMC) measures "typical" concentrations during a given year, in that a concentration can be expected to be greater than the geometric mean roughly half the time (about 180 days per year) and less than the geometric mean roughly half the time. Flow-averaged concentrations are estimates of concentrations that would have been measured assuming "typical" (flowaveraged) streamflow conditions, such that streamflow was the same year after year (Vecchia and Nustad, 2020).

The significance of trends was determined by a generalized likelihood ratio test statistic as described in Vecchia and Nustad (2020). For the current study, three levels of significance were used: a probability $(p)$ value less than or equal to 0.01 was considered significant; a $p$-value between 0.01 and 0.05 was considered mildly significant; and a $p$-value greater than 0.05 was considered nonsignificant. Small $p$-values were used to ensure that real trends were identified. For example, for a $p$-value less than 0.01 , at any given site and constituent, the chance that the fitted trend could have occurred given the null (no trend) hypothesis that the flow-adjusted concentrations were trend free is less than 1 percent (the data were trend free if their probability distribution remained the same for the trend-analysis period). Although conventional tests of significance are informative, selection of significance levels is somewhat discretionary (Giorgino and others, 2018); therefore, the direction and percentage of change were provided for all trends regardless of significance. A nonsignificant trend indicates that, given the available data, it could not be concluded that there was a trend (Helsel and Hirsch, 2002). This did not necessarily mean that the data were trend free, rather it means that the trend was too small to detect in relation to the natural variability in the data.

The period selected for trend analysis was important because results will vary by how the trend periods are structured (Giorgino and others, 2018). The recent period (2000-15) was selected because it was a period during which data were available for most sites and constituents and allowed for comparison of results between sites. For historical trend models, if enough data were available, three piecewise monotonic trends were specified: 1970-85, 1985-2000, and 2000-15; otherwise the combination of piecewise monotonic trends varied depending on data availability and known laboratory-analytical method changes. Note that the use of different data to develop trend models for the same site and period can result in slightly different results, but results should not contradict one another. For example, results from the historical trend models for the trend period 2000-15 can differ slightly from results presented for the recent trend model because additional observations of streamflow and water quality are being used in the model. For significant trends, the direction of the trend should be the same between the two models, but the percentage change of the trend and the $p$-value may differ slightly, but the values should be close. For nonsignificant trends, the results are affected more because of less certainty in the trend (as indicated by the large $p$-value) and might even seem to be contradictory. For example, for the same site and constituent during the same period (2000-15), it is possible to detect a small (less than 20 percent) nonsignificant decrease using the historical trend model and a small (less than 20 percent) nonsignificant increase using the recent trend model. Based on the low significance (large $p$-value) and small percentage change, these two trends can be interpreted the same way: concentrations are virtually unchanging for this site during this period.

For the recent trend period (2000-15), streamflow and water-quality data from 1997 to 2017 were used to analyze trends. Data were included, if available, for 3 years before the start of the trend period (1997-99) and for 2 years after the end of the trend period (2016-17). Including data collected before and after the trend period results in less uncertainty in the fitted trend compared to using a shorter dataset. For a constituent to be analyzed, the site had to have water-quality data starting no later than 2005; have at least 60 samples; and for constituents other than nitrate plus nitrite (previously described in the "Water-Quality Data Compilation" section), have no more than 25-percent censored data. For the historical trend period (1970-2015), streamflow and water-quality data from 1970 to 2017 were used to analyze trends. Based on data availability, sites 11, 15, 19, 26, and 33 (fig. 1 and table 1) were selected for trend analysis for the historical trend 
period. The trend models developed for each site, constituent, and trend period are available in a USGS data release (Nustad, 2020).

Water-quality and streamflow data were prepared using the R-QWTREND function prepQWdata(), and outliers identified from the prepQWdata() function were removed (Vecchia and Nustad, 2020). For the purposes of trend analysis, outliers should be identified and removed before analyzing trends. If they are not removed, it should be verified that they are not adversely affecting the model results (Vecchia and Nustad, 2020). Few outliers were identified and removed, consisting of less than 1 percent of the observations, which is less than the suggested maximum of 2 percent (Vecchia and Nustad, 2020). Trend models were compared against the null model using the maximum likelihood function, and model error codes were checked to ensure model convergence (Vecchia and Nustad, 2020).

To ensure trend results in the current study represent real environmental trends, data were tested for step trends caused by nonenvironmental factors such as differences in the part of the sample used in analysis (filtered or unfiltered), collection method, or laboratory-analytical method, and if significant step trends were detected, step trends were applied in R-QWTREND to correct for these differences. For sulfate, chloride, and total dissolved solids, step trends were applied for sites 20,29,32, and 33 to address either differences caused by unfiltered and filtered sample results or difference in laboratory-analytical methods among agencies (fig. 1, table 1; Nustad, 2020). To address data inconsistency caused by collection and laboratory-analytical method differences, step trends were applied for sites 21,22 , and 25 for total nitrogen or total phosphorus. For one tributary site (2) and main-stem U.S. sites $3,5,6,15$, and 20 , significant step trends were detected and applied to correct the low bias for total nitrogen and total phosphorus samples designated as supernate. All MSD sites were tested for a step trend in total phosphorus associated with the laboratory-analytical method change during April 2001 to March 2009. A significant high bias was detected for Manitoba sites $27,30,33$, and 34 , and a step trend was applied to correct the data down during this period to be consistent with total phosphorus results before April 2001 and after March 2009 (fig. 1 and table 1). Although the laboratory-analytical method change affected all MSD sites, a significant step trend was not detected for four of the tributary sites. The inability to detect a step trend for these four sites may be related to sparse data, low concentrations, and greater variability in the data for those sites. Site 26 was tested for a step trend because of the laboratory-analytical method change for total nitrogen on October 1, 1993. A significant low bias was detected for data before October 1, 1993, and a step trend was applied to correct data collected through September 30, 1993.

A special consideration in evaluating trends for Sheyenne River sites (7-11) and the Red River main-stem sites downstream from the Sheyenne River (sites 15, 20, 23, and 26) was potential changes to water quality related to the Devils Lake outlets. Devils Lake outlets were constructed by the
State of North Dakota, in response to more than a 30-foot lake level rise between 1993 and 2011, to discharge water from Devils Lake to the Sheyenne River (North Dakota State Water Commission, 2019a). The West End Outlet was operational in 2005 but did not start discharging until 2008. The East End Outlet started discharging in 2012. Devils Lake, a naturally closed lake basin, has higher concentrations of dissolved ions (sulfate, chloride, and total dissolved ions), especially sulfate, compared to the Red River (Vecchia, 2008). Sulfate is the main concern for downstream water bodies because concentrations from the East End Outlet discharges are typically about 1,000 $\mathrm{mg} / \mathrm{L}$ and, from the West End Outlet, about $600 \mathrm{mg} / \mathrm{L}$ compared with a median concentration of $187 \mathrm{mg} / \mathrm{L}$ for Red River main-stem site 15 (fig. 1 and table 2 [available for download at https://doi.org/10.3133/sir20205079]; North Dakota State Water Commission, 2019b). Water-quality changes related to the outlets were addressed by applying a user-specified ancillary trend variable in R-QWTREND (Vecchia and Nustad, 2020; appendix 1) to remove the effects of the outlets. Effects of the outlets on nutrient and total suspended solids concentrations were determined to be negligible, but for dissolved ions (sulfate, chloride, and total dissolved solids), changes because of the outlet were identified and trends were analyzed with the effects of the outlets or "withoutlet" conditions and with the effects of the outlets removed or "no-outlet" conditions. A comparison of results between with-outlet and no-outlet conditions determined that the effect of Devils Lake outlets on annual dissolved ions concentrations was large for some years for sites on the Sheyenne River but was reduced for sites farther downstream on the Red River and became relatively small at the binational site (site 26; appendix 1). In the main body of this report, all trend results for dissolved ions are presented for no-outlet conditions.

\section{Water-Quality Trends for Selected Sampling Sites in the Red River of the North Basin}

Because R-QWTREND removes natural variability in constituent concentration caused by variability in streamflow, identified trends were assumed to be related to something other than natural streamflow variability. Other activities that could potentially affect trends include changes in land use, agricultural practices, livestock production, and urban or industrial development. Results of water-quality trend analysis for sites and constituents used for the current study are summarized in this section.

\section{Recent Water-Quality Trends}

Trends in concentrations of 7 constituents for the recent period (2000-15) were analyzed for 34 sites; however, depending on data availability, all constituents were not 
analyzed for all sites. As previously mentioned, the trend is referred to as a "flow-averaged" trend because it is an estimate of the annual GMC under the hypothetical assumption that the flow-related variability was the same year after year (Vecchia and Nustad, 2020). Trends are reported in terms of direction, percentage change, and magnitude of change in annual FAGMC from the first year to the last year of the period. Trend results for all constituents are presented in three parts: first, a map of sites showing the direction and significance of trends across the basin; second, a multipart figure with two plots: (1) a plot showing the direction and significance of the trend and the change in annual FAGMC from the start to the end of the trend period and (2) a plot showing direction and significance of the trend and the annual FAGMC at the start and end of the trend period. In the second plot, although WQOs are applicable only to the binational site (site 26) and proposed nutrient WQOs are applied as a seasonal average (April 1-October 30), the WQO was included on the plot to provide basinwide perspective. For example, if the FAGMCs of tributaries are less than the WQO, these tributaries are likely not contributing to exceedances of the WQO at the border between the United States and Canada.

\section{Sulfate, Chloride, and Total Dissolved Solids}

Trends in sulfate concentrations may result from atmospheric deposition or land-use and climate changes, which may increase or decrease the exposure of naturally occurring sulfur in runoff. Some studies have linked increasing sulfate concentrations to urbanization (Kaushal and others, 2018). Sulfur is abundant in the soils throughout the Red River Basin but is especially abundant in the saline soils of the western part of the basin in North Dakota (Stoner and others, 1993). Reduced sulfur compounds readily oxidize to produce sulfate ions, which are highly soluble (Hem, 1985). Saline soils in North Dakota contain a mixture of salts, with sulfates being the most dominant form (Franzen, 2007). High solubility combined with abundance results in high concentrations of sulfate in North Dakota streams. The highest median concentrations for sulfate were in the Sheyenne River and other North Dakota tributaries, and the lowest median concentrations were in Manitoba tributaries (table 2). Median concentrations of sulfate across the basin ranged from $14.0 \mathrm{mg} / \mathrm{L}$ at Manitoba tributary site 32 to $510 \mathrm{mg} / \mathrm{L}$ at North Dakota tributary site 2 (table 2). Minnesota tributaries had too few sulfate data for trend analysis during the recent period.

Sulfate concentrations increased across the basin during 2000-15 (table 3 [available for download at https://doi.org/ 10.3133/sir20205079], figs. 2 and 3). Previous studies have determined increasing sulfate concentrations for streams in North Dakota and the Red River Basin (Vecchia, 2003; Vecchia, 2005; Galloway and others, 2012). Of the 28 sites with enough data to analyze for trends, 26 sites had increasing sulfate concentrations, and 20 of the increases were significant or mildly significant. Only two Manitoba tributaries (sites 28 and 34) had decreasing sulfate concentrations, and both were significant. The magnitudes of the mildly significant or significant increases were substantial for many of the sites, with 11 sites having increases of 40 percent or greater (fig. $3 A$ ). There were 16 sites with increases in annual FAGMC of $50 \mathrm{mg} / \mathrm{L}$ or more from 2000 to 2015 (table 3), including all three Manitoba main-stem sites (26, 30, and 33), and the largest increase was more than $200 \mathrm{mg} / \mathrm{L}$ for site 2 . Using the WQO of $250 \mathrm{mg} / \mathrm{L}$ set for sulfate at the binational site (26) as a reference, across the basin by 2015 , the FAGMC was greater than $250 \mathrm{mg} / \mathrm{L}$ for 11 sites, all of which were tributary sites upstream from the binational site (fig. $3 B$ ). However, all the main-stem sites had a FAGMC less than $250 \mathrm{mg} / \mathrm{L}$, probably because of dilution from Minnesota tributaries, which (though none had enough data to analyze trends) were expected to have low sulfate concentrations compared to North Dakota tributaries. Tributaries in Manitoba had the lowest FAGMC for sulfate.

Trends in chloride have been linked to human activities, such as urbanization and road deicing (Corsi and others, 2015; Kaushal and others, 2018; Stets and others, 2018). Urbanization in the basin is concentrated in the major cities of Fargo and Grand Forks, N. Dak., and Winnipeg, Manitoba. Chloride is naturally occurring in Red River soils, not as abundantly as sulfur, and is highly soluble (Hem, 1985; Stoner and others, 1993). Chloride is a dominant ion in sedimentary bedrock aquifers in the basin, resulting in high chloride concentrations in groundwater of this aquifer type (Stoner and others, 1993). Median concentrations of chloride ranged from $5.69 \mathrm{mg} / \mathrm{L}$ at Manitoba tributary site 27 to $75.0 \mathrm{mg} / \mathrm{L}$ at Manitoba tributary site 31 (table 2). Minnesota tributaries had too few data for trend analysis in the recent period.

Like sulfate, chloride concentrations increased for most sites during the recent trend period (table 3, figs. 4 and 5). Of the 28 sites with enough data for trend analysis, 21 sites had increasing chloride concentrations, including 10 sites with significant increases and four sites with mildly significant increases (figs. 4 and $5 A$ ). Main-stem sites all had significant or mildly significant increases in chloride concentrations ranging from 18 to 65 percent. Across the basin, by the end of the recent period, despite these increases, the FAGMC for chloride was less than $50 \mathrm{mg} / \mathrm{L}$ for all sites analyzed except three of the tributary sites, and for all three of those tributary sites, the FAGMC was much less than the WQO of $100 \mathrm{mg} / \mathrm{L}$ set for the binational site (fig. $5 B$ ). The largest increase in FAGMC from 2000 to 2015 was about $17 \mathrm{mg} / \mathrm{L}$ ( 65 percent) for the Red River at South Gate of Floodway (site 30; table 3 and fig. 5A).

The total dissolved solids concentration, a measure of the sum of major dissolved ions such as calcium, magnesium, sodium, potassium, sulfate, chloride, and many other constituents present in small amounts (Vecchia, 2005), is affected by the same factors that affect any one or all of these constituents. It is possible for one constituent to drive the total dissolved solids trend or for individual constituents to have trends in opposite directions, cancelling out the trend in total dissolved solids. For this reason, trends in total dissolved solids can be more difficult to interpret. Depending on the abundance of 


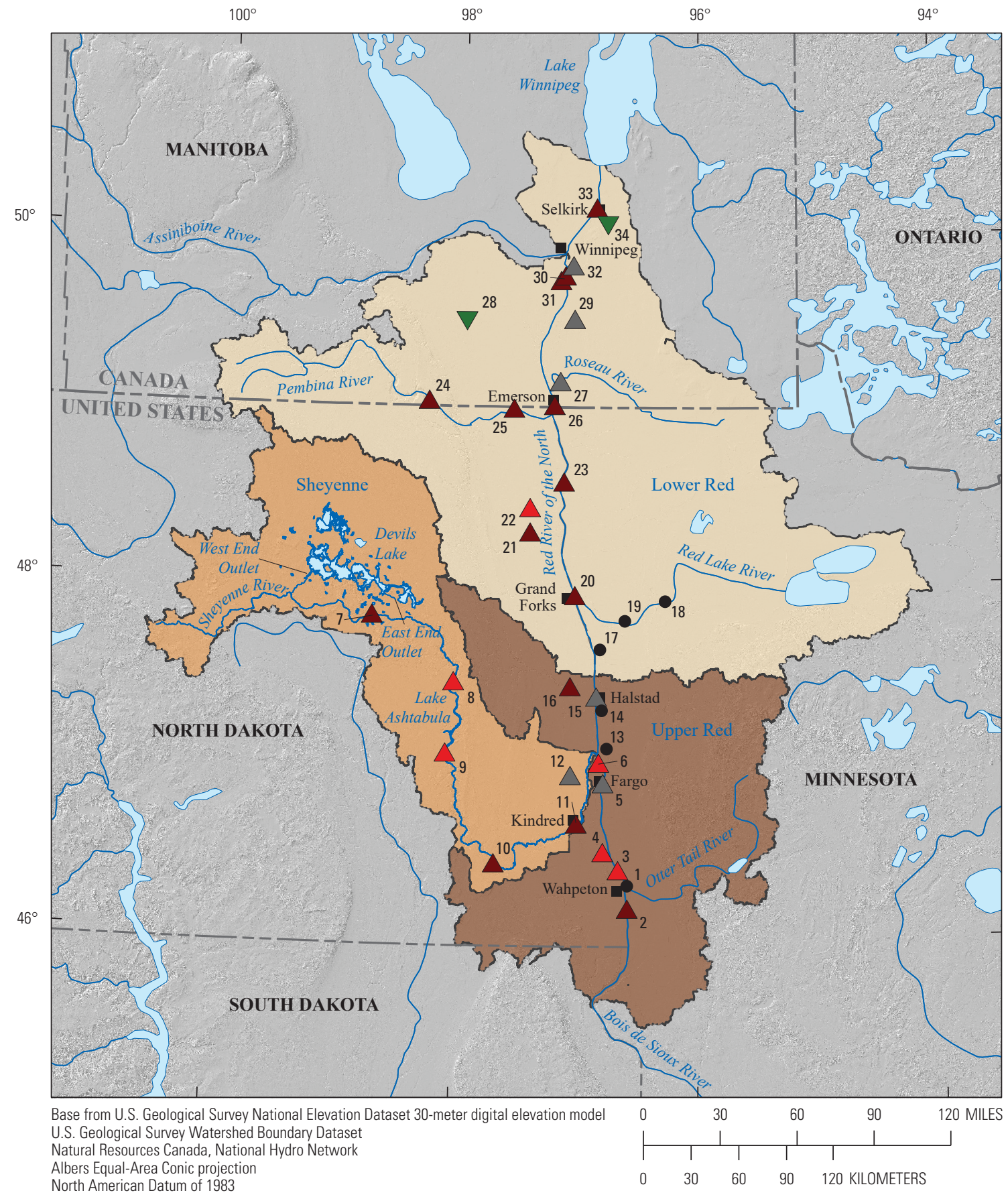

\section{EXPLANATION}

\begin{tabular}{|c|c|}
\hline Subbasins & Too few data and site number \\
\hline Lower Red & Significant increase and site number \\
\hline Sheyenne & Mildly significant increase and site number \\
\hline Upper Red & $\begin{array}{l}\text { Nonsignificant increase and site number } \\
\text { Significant decrease and site number }\end{array}$ \\
\hline
\end{tabular}

Figure 2. Direction and significance of trends in sulfate concentration evaluated for the recent period 2000-15 at selected sites in the Red River of the North Basin. 


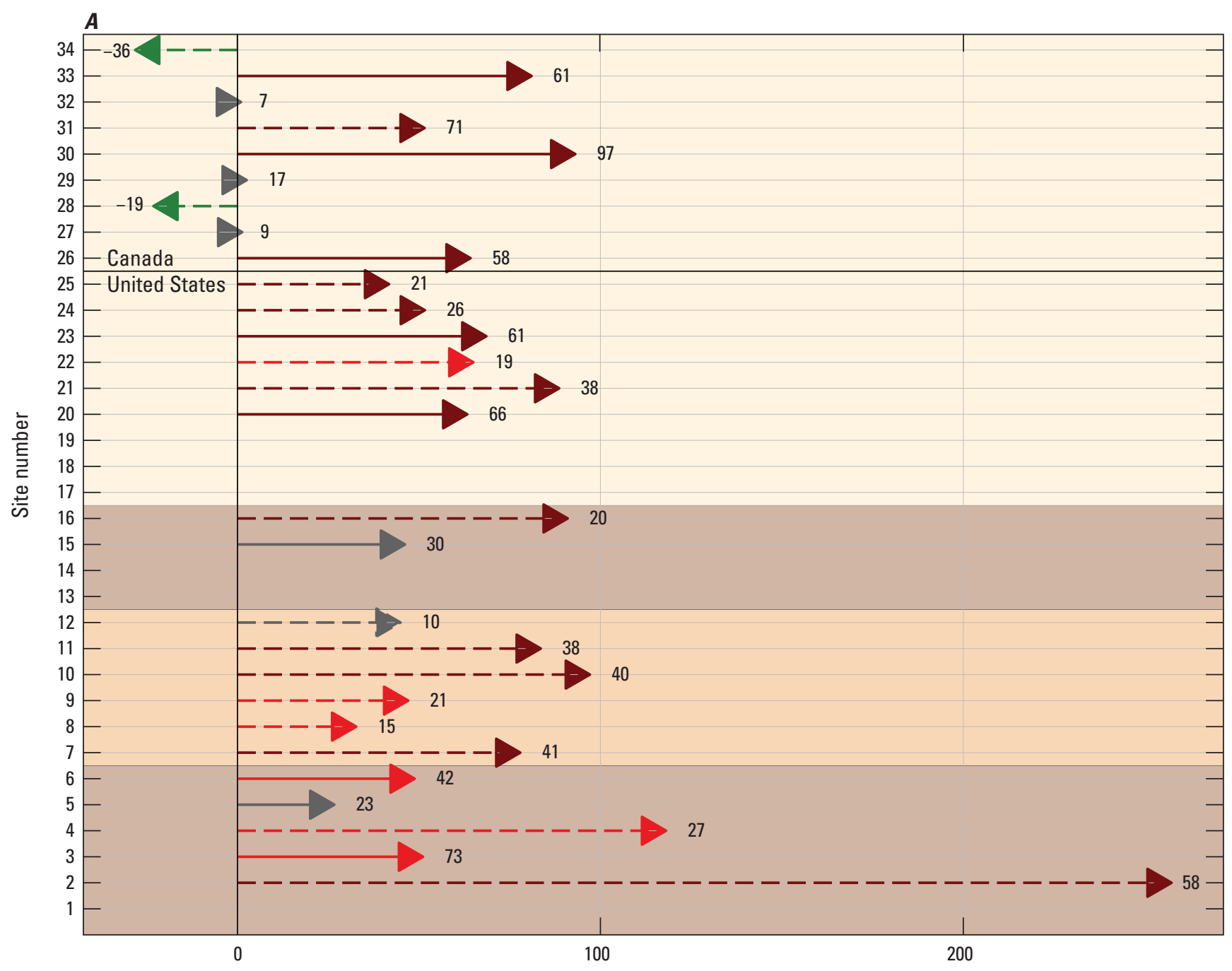

Change in annual flow-averaged geometric mean sulfate concentration from first year to last year of trend period (2000-15), in milligrams per liter

\section{EXPLANATION}

\begin{tabular}{|c|c|c|c|c|}
\hline \multirow[t]{2}{*}{58} & Change in percent & Main-stem site & --- & Tributary site \\
\hline & Subbasins & Main-stem site & --- & Tributary site \\
\hline & Lower Red & Main-stem site & --- & Tributary site \\
\hline & Sheyenne & & --- & Tributary site \\
\hline & Upper Red & & & \\
\hline
\end{tabular}

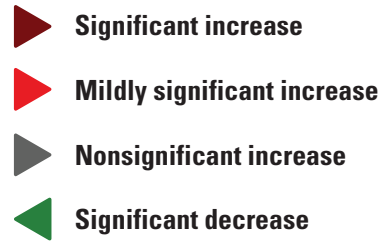

Figure 3. Trends in sulfate concentration evaluated for the recent period 2000-15 at selected sites in the Red River of the North Basin. $A$, change in annual flow-averaged geometric mean concentration from first year to last year of the trend period; $B$, annual flow-averaged geometric mean concentration from first year to last year of the trend period. [Shading corresponds to the subbasins in figure 2] 


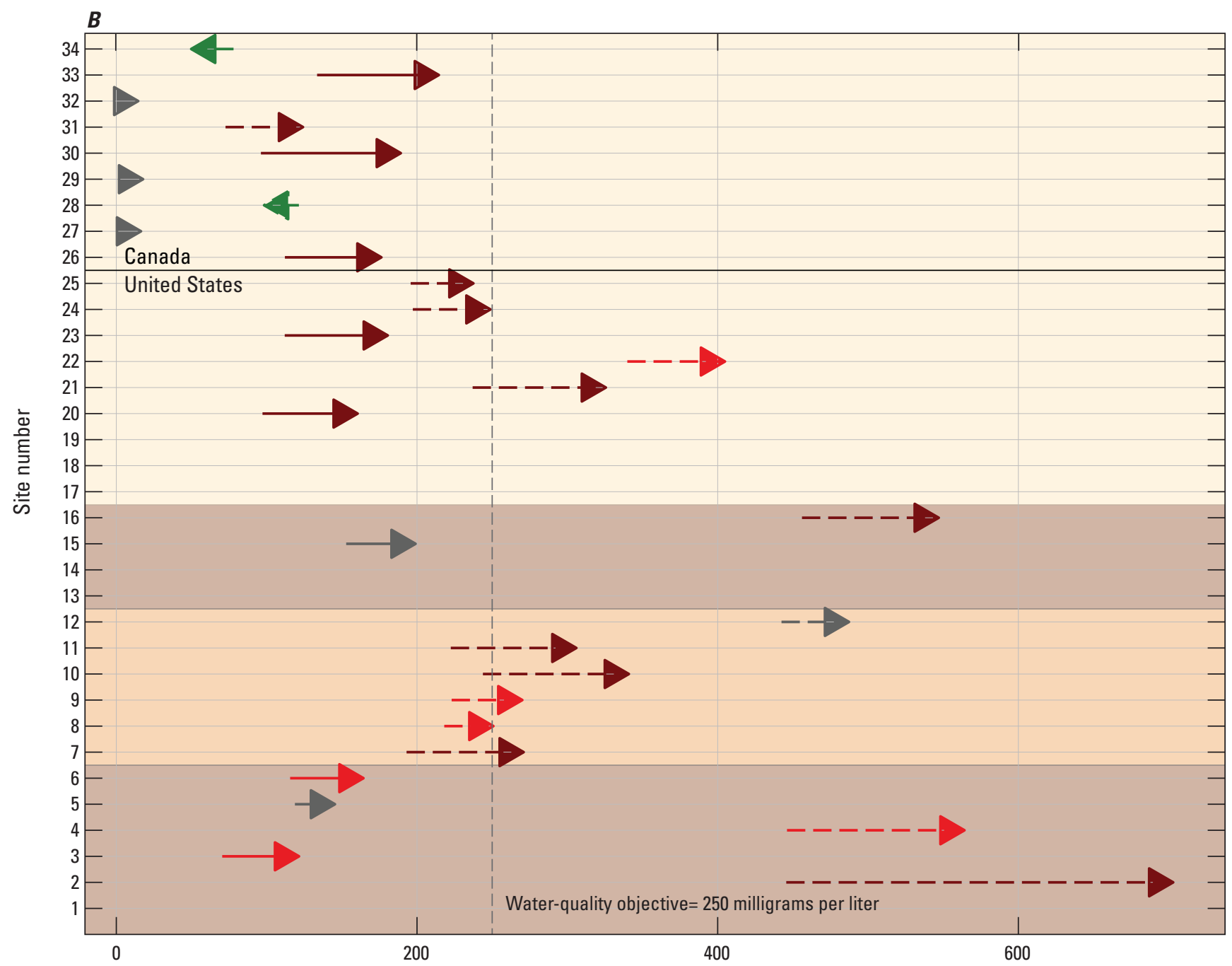

Annual flow-averaged geometric mean sulfate concentration from first year to last year of trend period (2000-15), in milligrams per liter

\section{EXPLANATION}

\begin{tabular}{|c|c|c|c|c|}
\hline Subbasins & Main-stem site & --- & Tributary site & Significant increase \\
\hline Lower Red & Main-stem site & --- & Tributary site & Mildly significant increase \\
\hline Sheyenne & Main-stem site & --- & Tributary site & Nonsignificant increase \\
\hline Upper Red & & --- & Tributary site & Significant decrease \\
\hline
\end{tabular}

Figure 3. Trends in sulfate concentration evaluated for the recent period 2000-15 at selected sites in the Red River of the North Basin. $A$, change in annual flow-averaged geometric mean concentration from first year to last year of the trend period; $B$, annual flow-averaged geometric mean concentration from first year to last year of the trend period. [Shading corresponds to the subbasins in figure 2] - Continued 


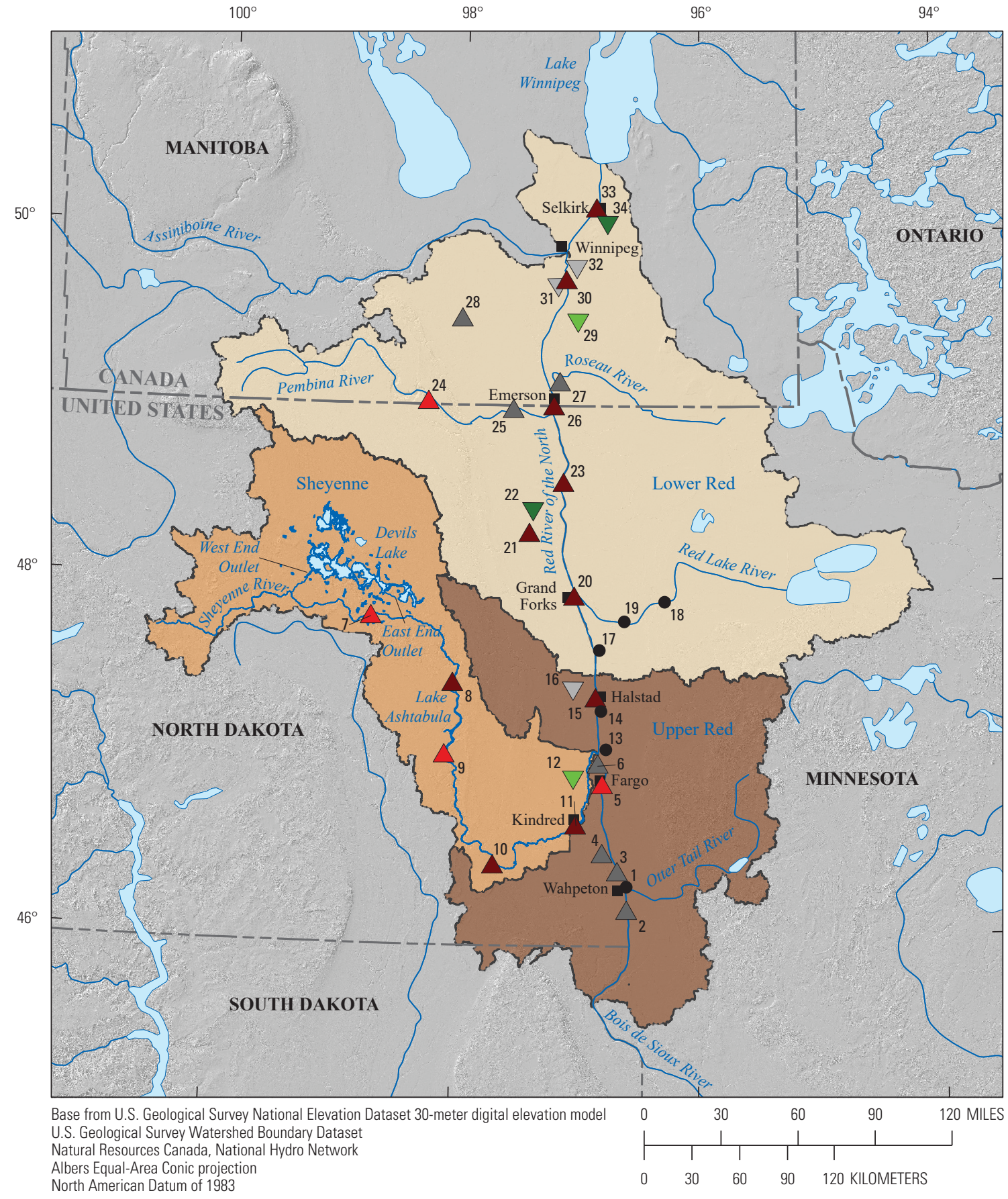

EXPLANATION

\begin{tabular}{|c|c|c|}
\hline Subbasins & Too few data and site number & Nonsignificant decrease and site number \\
\hline Lower Red & Significant increase and site number & Mildly significant decrease and site number \\
\hline Sheyenne & Mildly significant increase and site number & Significant decrease and site number \\
\hline Upper Red & Nonsignificant increase and site number & \\
\hline
\end{tabular}

Figure 4. Direction and significance of trends in chloride concentration evaluated for the recent period 2000-15 at selected sites in the Red River of the North Basin. 


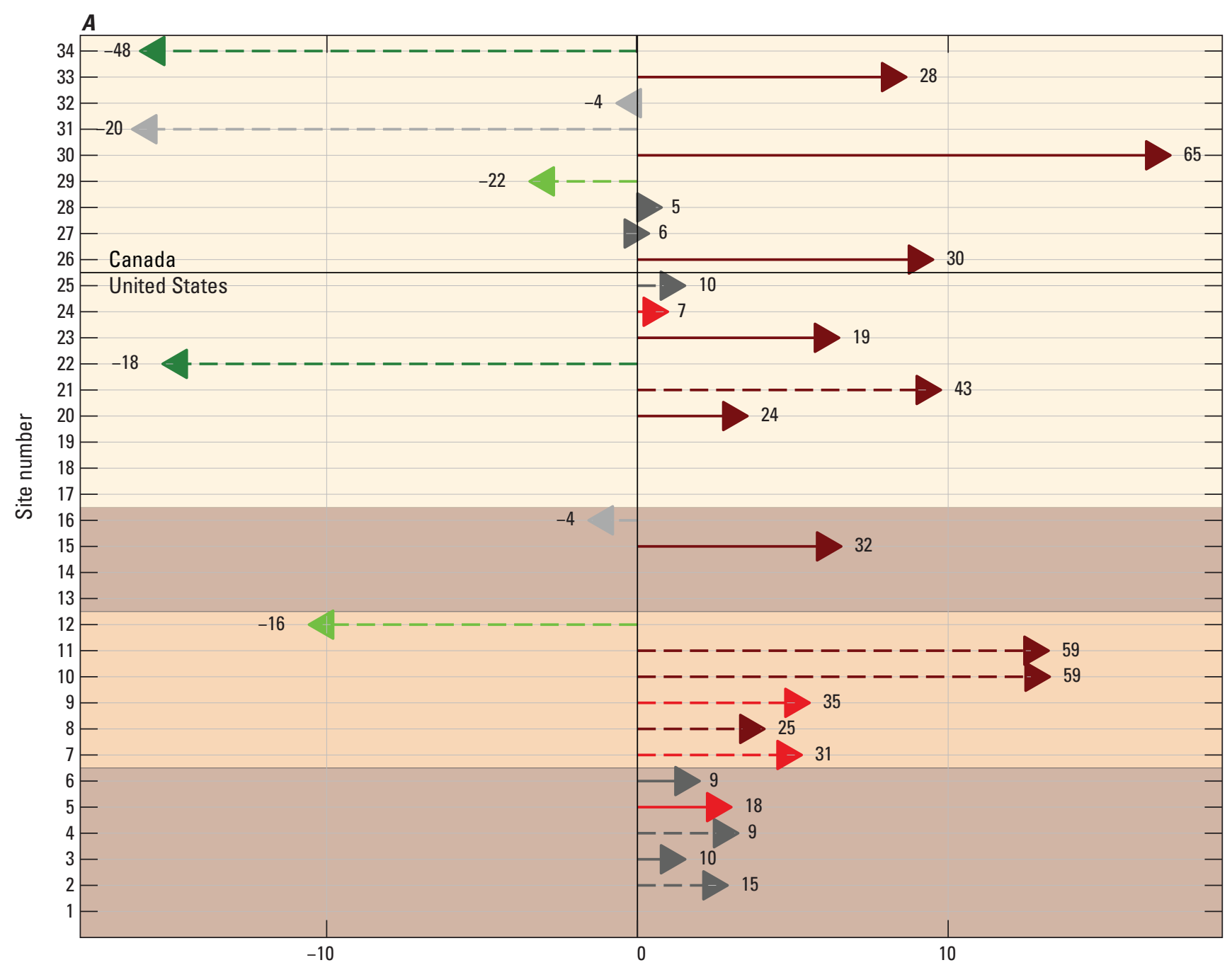

Change in annual flow-averaged geometric mean chloride concentration from first year to last year of trend period (2000-15), in milligrams per liter

\section{EXPLANATION}
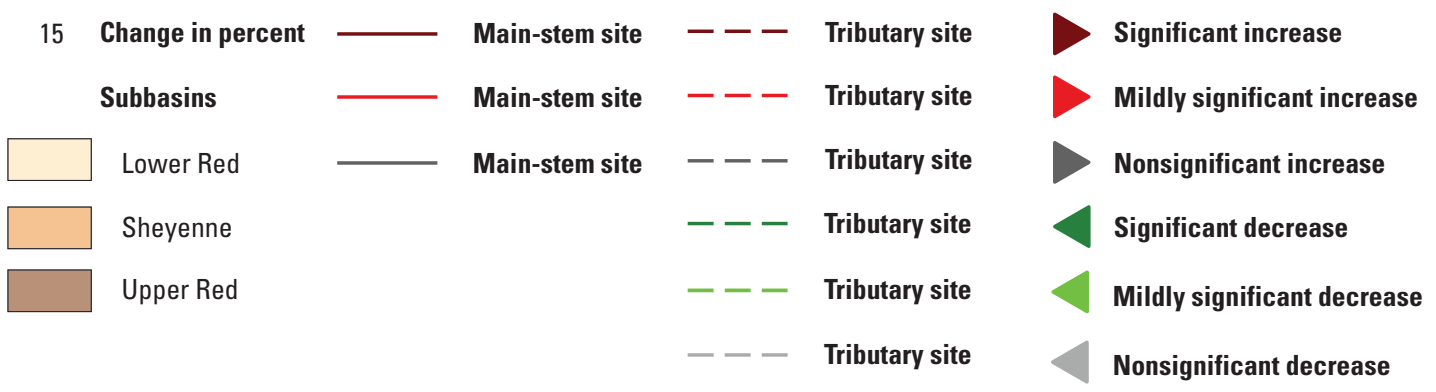

Figure 5. Trends in chloride concentration evaluated for the recent period 2000-15 at selected sites in the Red River of the North Basin. $A$, change in annual flow-averaged geometric mean concentration from first year to last year of the trend period; $B$, annual flow-averaged geometric mean concentration from first year to last year of the trend period. [Shading corresponds to the subbasins in figure 4] 


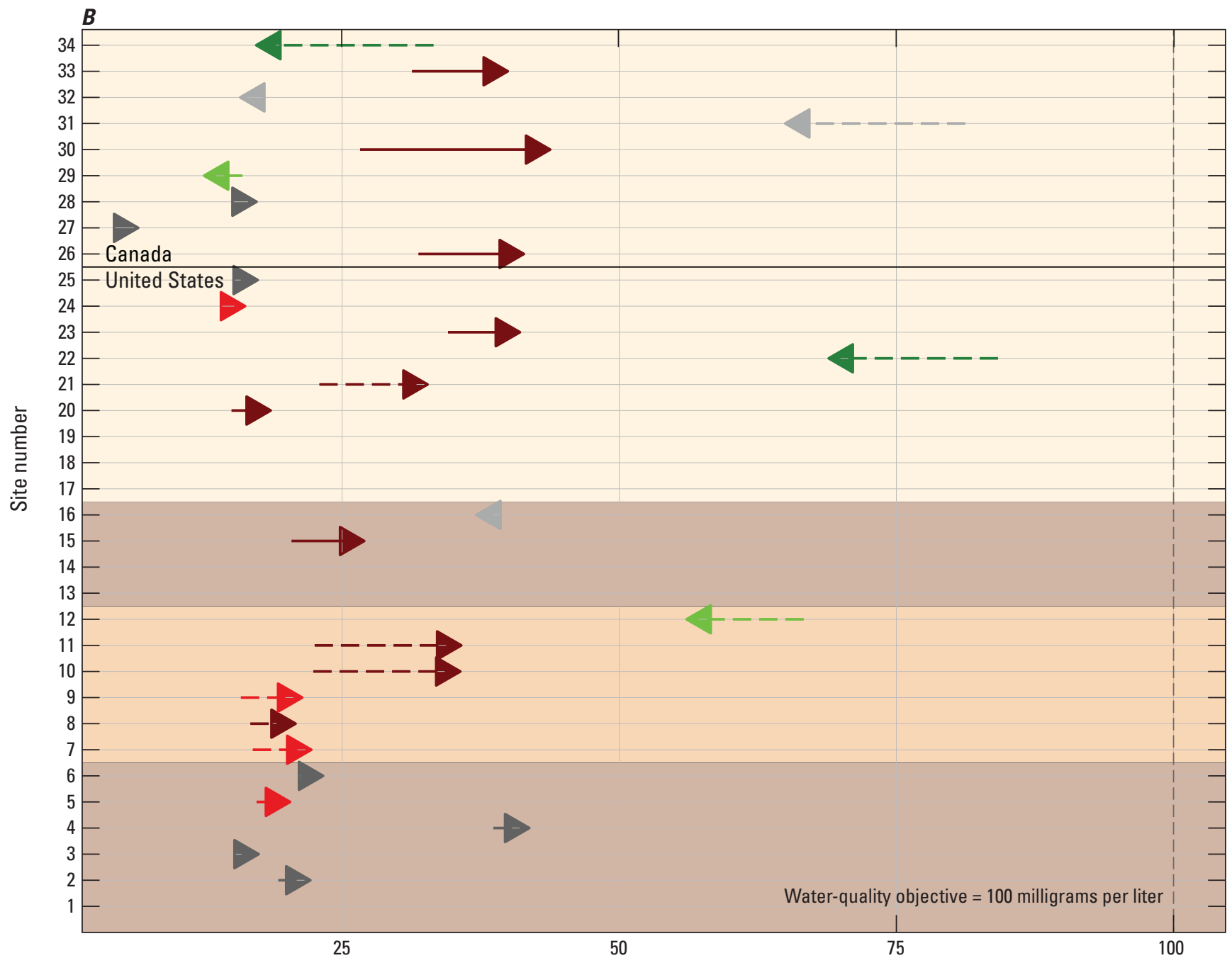

Annual flow-averaged geometric mean chloride concentration from first year to last year of trend period (2000-15), in milligrams per liter

\section{EXPLANATION}

\begin{tabular}{|c|c|c|c|c|}
\hline Subbasins & Main-stem site & --- & Tributary site & Significant increase \\
\hline Lower Red & Main-stem site & --- & Tributary site & Mildly significant increase \\
\hline Sheyenne & Main-stem site & --- & Tributary site & Nonsignificant increase \\
\hline Upper Red & & --- & Tributary site & Significant decrease \\
\hline & & --- & Tributary site & Mildly significant decrease \\
\hline & & --- & Tributary site & Nonsignificant decrease \\
\hline
\end{tabular}

Figure 5. Trends in chloride concentration evaluated for the recent period 2000-15 at selected sites in the Red River of the North Basin. $A$, change in annual flow-averaged geometric mean concentration from first year to last year of the trend period; $B$, annual flow-averaged geometric mean concentration from first year to last year of the trend period. [Shading corresponds to the subbasins in figure 4]—Continued 
any one of the major ions, a single constituent can dominate the concentration of total dissolved solids, and the dominant constituent varies by location, dependent on local geology and soils. Because sulfur is abundant in the soils in the western part of the basin, sulfate can account for a substantial fraction, as much as about 50 percent of the total dissolved solids for some sites, but in other parts of the basin, sulfate may account for a small fraction of total dissolved solids. Median total dissolved solids concentrations ranged from $333 \mathrm{mg} / \mathrm{L}$ at Manitoba tributary site 32 to $1,020 \mathrm{mg} / \mathrm{L}$ at North Dakota tributary site 16 (table 2). The highest total dissolved solids concentrations were in the North Dakota tributaries, and the lowest concentrations generally were in Manitoba tributaries. Too few data were available for trend analysis of total dissolved solids for Minnesota tributaries in the recent period.

Like sulfate and chloride, total dissolved solids concentrations increased for most sites during the recent trend period (table 3, figs. 6 and 7). Of the 28 sites with enough data for trend analysis, 22 sites had increasing total dissolved solids concentrations, and 17 of the increases were significant or mildly significant (fig. 6). All but one of the U.S. tributary sites had increasing concentrations, including seven significant increases, and all nine of the main-stem sites had increasing concentrations, including eight significant or mildly significant increases (fig. 7A). In contrast, of the six Manitoba tributaries wholly in Canada, five had decreasing concentrations (although only two were significant), and Manitoba tributary site 31 had a mildly significant increasing concentration. The magnitudes of the percentage increase for mildly significant and significant sites for total dissolved solids were smaller than sulfate with increases less than 40 percent, but the increases in FAGMC were substantial for many of the sites (figs. $7 A$ and $7 B$ ). For 13 sites, including 6 of the mainstem sites, the FAGMC increased by more than $100 \mathrm{mg} / \mathrm{L}$ from 2000 to 2015 . Using the WQO of $500 \mathrm{mg} / \mathrm{L}$ set for total dissolved solids at the binational site as a reference, across the basin by the end of the recent period (2015), the annual FAGMC for total dissolved solids was greater than $500 \mathrm{mg} / \mathrm{L}$ for 20 of the 28 sites analyzed, including 6 of 9 main-stem sites (fig. 7B). At the start of the trend period (2000), the FAGMC was less than $500 \mathrm{mg} / \mathrm{L}$ for all nine main-stem sites. For most sites, the increasing sulfate concentrations (fig. $3 \mathrm{~A}$ ) were more than one-half of the magnitude of the total dissolved solids increases, indicating that sulfate accounted for at least one-half of the increase in total dissolved solids for those sites. For two sites (2 and 4), the increase in sulfate concentration was substantially larger than the increase in total dissolved solids concentration (figs. $3 A$ and $7 A$ ). Although this may indicate that decreases in concentrations of other dissolved constituents could have offset the large increases in sulfate concentration for those two sites, it is more likely that the discrepancy is due to uncertainty in the estimated trend magnitudes.

In R-QWTREND, natural (hydroclimatic) variability in concentration is modeled and removed using daily streamflow, which reflects changes in the timing and amount of basin runoff as a result of changes in climatic conditions. For each time step $(t)$, the R-QWTREND variable, FRVAR, models and removes complex flow-related variability in constituent concentration, $C(t)$, based on antecedent streamflow for 1 year up to and including the current time step (Vecchia and Nustad, 2020). Thus, R-QWTREND often removes much more flowrelated variability compared to other methods that use only concurrent (not antecedent) streamflow to model flow-related variability; however, FRVAR, though complex, is assumed to be stationary. That is, the relation between $C(t)$ and antecedent streamflow does not change. For example, if daily streamflow for the year leading up to June 1, 2000 (time $t_{1}$ ), happens to be identical (or at least very similar) to daily streamflow for the year leading up to June 1, 2015 (time $t_{2}$ ), then FRVAR for times $t_{1}$ and $t_{2}$ also would be identical (or very similar). To the extent that FRVAR is stationary, the consistent increases across the basin in sulfate, chloride, and total dissolved solids (referred to here as "salts") for the recent period (2000-15) are likely linked, in part, to widespread changes in land use, agricultural practices, livestock production, and urban or industrial development. In North America, particularly in snow affected areas, salinization (increasing salt concentrations) of streams has been linked with urbanization, road-salt application, agricultural activities, and shifts in precipitation patterns (Corsi and others, 2015; Kaushal and others, 2018; Stets and others, 2018). In the basin, recent land-use changes in response to wetter conditions, such as changes to drainage pathways, either surface or subsurface, and changes to crop management and types of crops planted, have been determined to result in increased amount of salts in surface-water runoff and shallow groundwater (Schuh and Hove, 2006).

The large magnitude and overall consistency of the upward trends among tributary and main-stem sites across the basin, particularly for sulfate and total dissolved solids (figs. $3 A$ and $7 A$ ), may indicate that natural (hydroclimatic) processes, processes unrelated to human activities on the landscape that cannot be explained by streamflow alone, are contributing to increases in the amount of salts in basin runoff during the recent (2000-15) period of generally wetter climatic conditions. Although streamflow explains changes in the amount and timing of basin runoff in response to hydroclimatic change, there may be long-term (multidecadal) changes in the chemical composition of runoff that are unrelated to the amount and timing of runoff and that respond much more slowly to hydroclimatic change compared to streamflow. Even though streamflow in the basin has remained relatively stable since the late 1990s, salts deep within the soil profile may be slowly migrating toward the surface or laterally toward stream channels in response to rising groundwater tables. This process may persist for many years, perhaps decades, before reaching an equilibrium. The slowly increasing supply of natural salts near the surface or near stream channels could cause a nonstationary relation between streamflow and concentration, which manifests itself as a trend. For example, the concentration on June 1, 2015, might be substantially higher than the concentration on June 1,2000, even if streamflow for the 


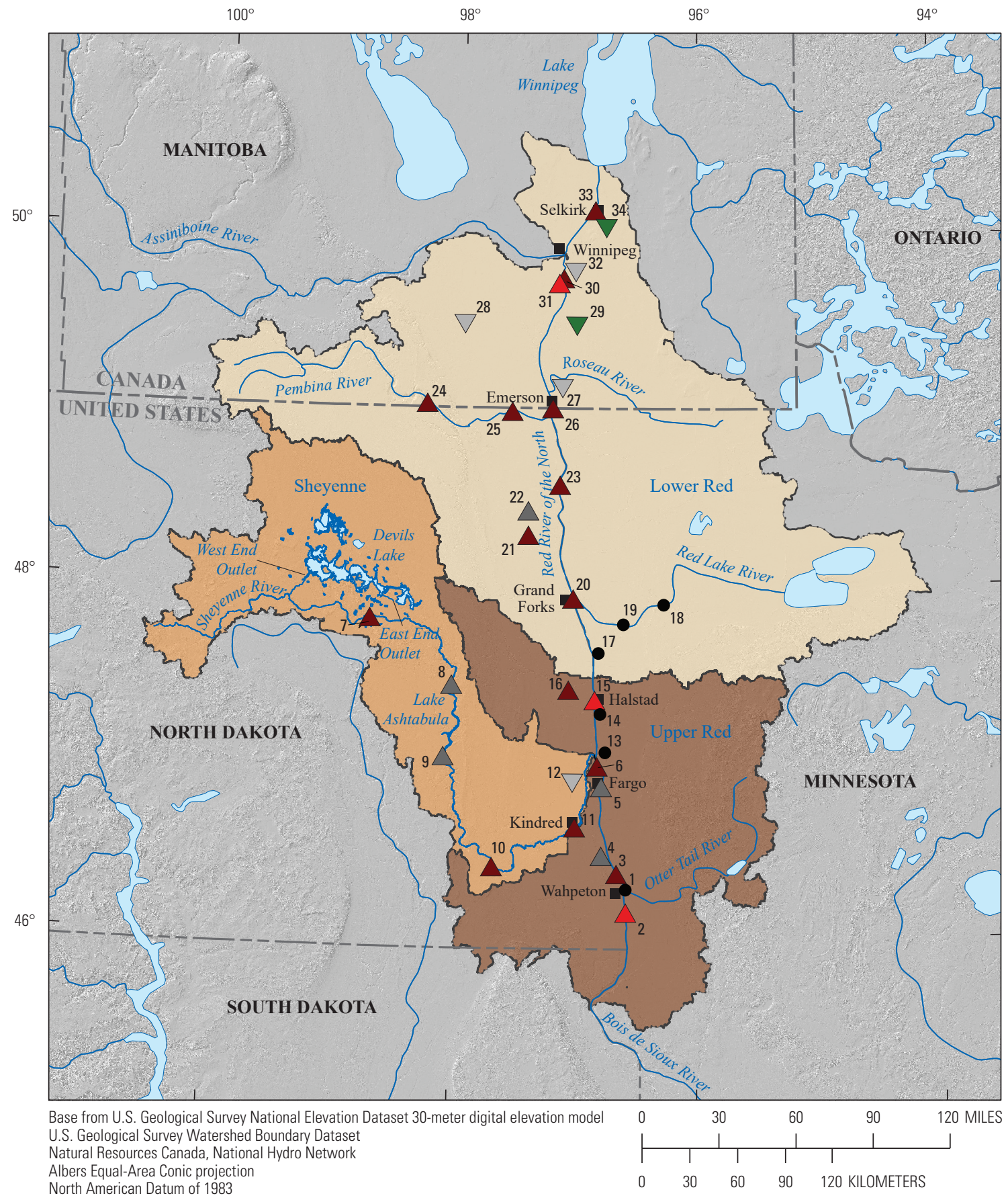

EXPLANATION

\begin{tabular}{|c|c|c|}
\hline Subbasins & Too few data and site number & Nonsignificant decrease and site number \\
\hline Lower Red & Significant increase and site number & Significant decrease and site number \\
\hline Sheyenne & Mildly significant increase and site number & \\
\hline Upper Red & Nonsignificant increase and site number & \\
\hline
\end{tabular}

Figure 6. Direction and significance of trends in total dissolved solids concentration evaluated for the recent period 2000-15 at selected sites in the Red River of the North Basin. 


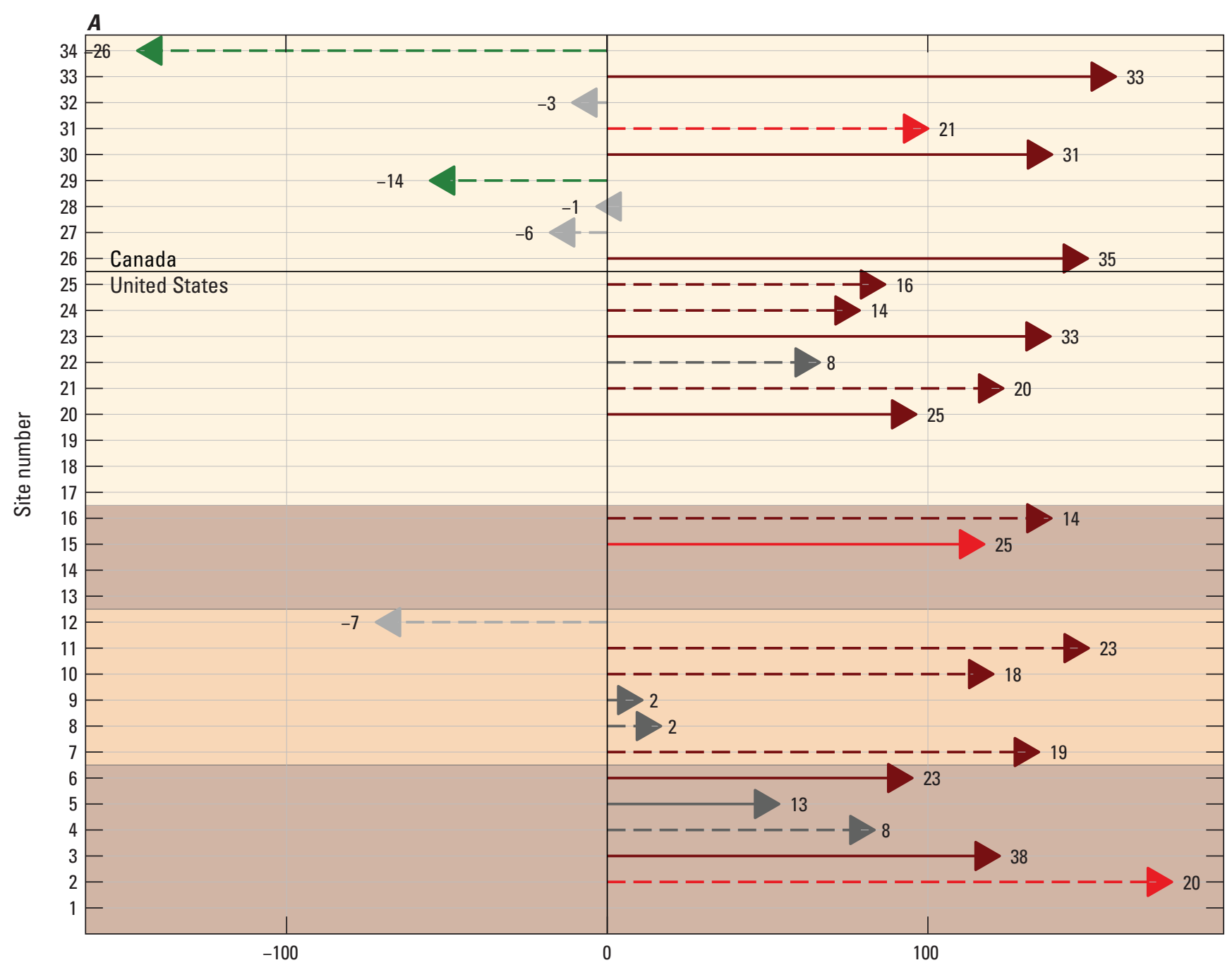

Change in annual flow-averaged geometric mean total dissolved solids concentration from first year to last year of trend period (2000-15), in milligrams per liter

\section{EXPLANATION}

\begin{tabular}{|c|c|c|c|c|c|}
\hline 20 & $\begin{array}{l}\text { Change in percent } \\
\text { Subbasins }\end{array}$ & $\begin{array}{l}\text { Main-stem site } \\
\text { Main-stem site }\end{array}$ & $\begin{array}{l}--- \\
---\end{array}$ & $\begin{array}{l}\text { Tributary site } \\
\text { Tributary site }\end{array}$ & $\begin{array}{l}\text { Significant increase } \\
\text { Mildly significant increase }\end{array}$ \\
\hline & Lower Red & Main-stem site & --- & Tributary site & Nonsignificant increase \\
\hline & Sheyenne & & --- & Tributary site & Significant decrease \\
\hline & Upper Red & & --- & Tributary site & Nonsignificant decrease \\
\hline
\end{tabular}

Figure 7. Trends in total dissolved solids concentration evaluated for the recent period 2000-15 at selected sites in the Red River of the North Basin. $A$, change in annual flow-averaged geometric mean concentration from first year to last year of the trend period; $B$, annual flow-averaged geometric mean concentration from first year to last year of the trend period. [Shading corresponds to the subbasins in figure 6] 


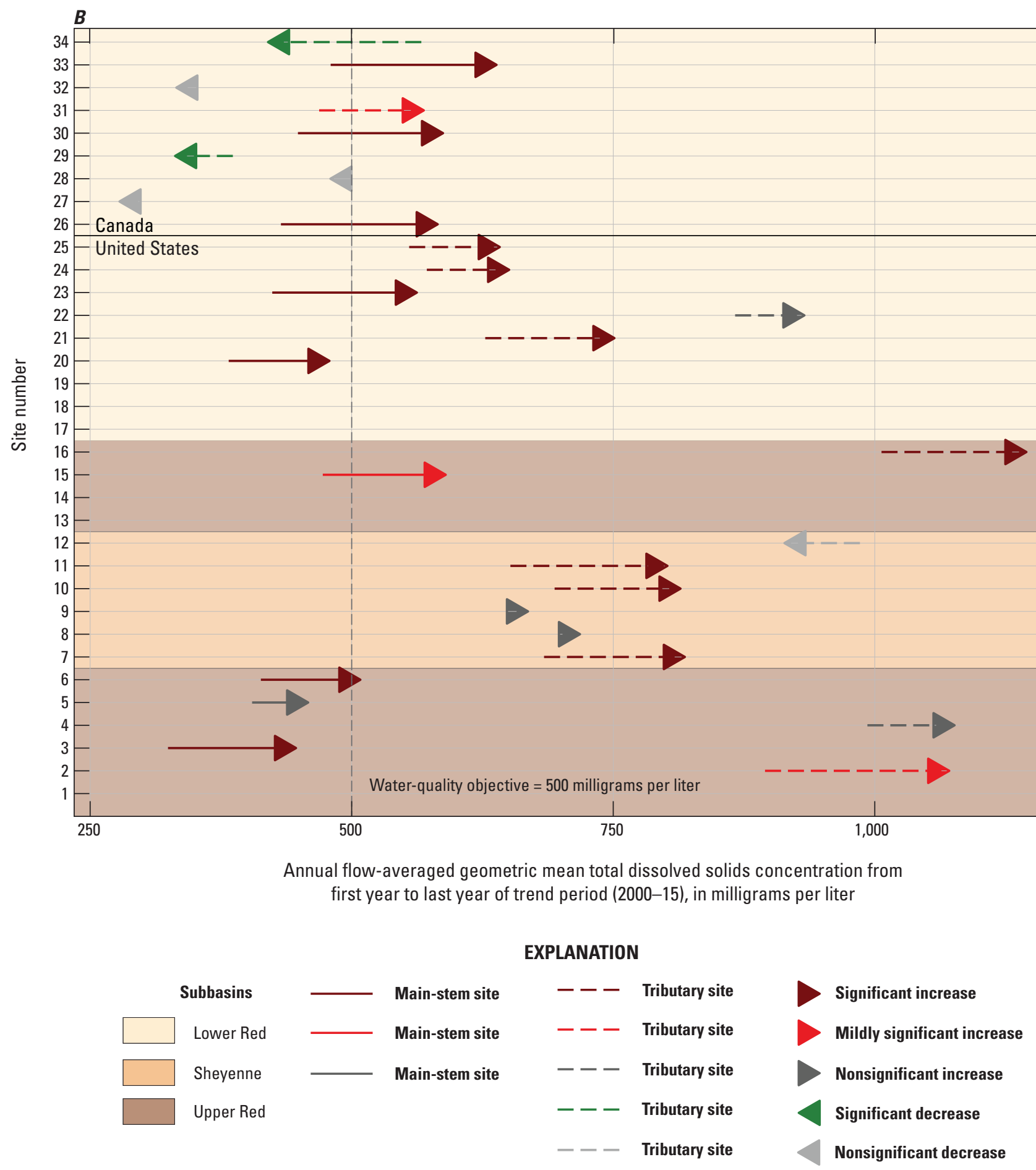

Figure 7. Trends in total dissolved solids concentration evaluated for the recent period 2000-15 at selected sites in the Red River of the North Basin. $A$, change in annual flow-averaged geometric mean concentration from first year to last year of the trend period; $B$, annual flow-averaged geometric mean concentration from first year to last year of the trend period. [Shading corresponds to the subbasins in figure 6]—Continued 
years leading up to both days were identical. In the Red River Basin, rising groundwater tables and increases in contributing drainage areas induced by natural hydroclimatic changes have been linked with increases in sulfate (Vecchia, 2005; Schuh and Hove, 2006). Since the 1990s, coincident with a wet climate state in North Dakota and South Dakota, largescale salinization of surface soil has been observed (Schuh and Hove, 2006). Relatively higher precipitation years raise watertable levels and bring salts near the surface (Schuh and Hove, 2006; Franzen, 2007). These changes increase connectivity of subsurface flow with streams, resulting in a readily available, highly concentrated source of salts to streams. Higher water-table levels also introduce sulfate at streambanks and drainageways and increase integration of saline wetlands with rivers (Schuh and Hove, 2006). In the Red River Basin, consistent increasing concentrations of sulfate, chloride, and total dissolved solids are likely linked to changes in the landscape, but natural hydroclimatic changes are also likely increasing the amount of salts reaching streams through surface and subsurface runoff.

\section{Nutrients}

Nutrients are essential to plant growth and consist of compounds that contain nitrogen or phosphorus. As nutrients become overly abundant in streams and rivers, eutrophication of the receiving water body begins to occur. Lake Winnipeg, the receiving water body of the Red River, has been developing increasingly severe algal blooms, which is an indication of excess nutrients leading to eutrophication (Environment Canada and Manitoba Water Stewardship, 2011). Nutrient dynamics are complex and controlled by anthropogenic activities in the basin and instream processes. Changes that can affect trends in nutrient concentrations in the basin include changes in agricultural management practices, residential or agricultural fertilizer usage, the Conservation Reserve Program (CRP), livestock production, and industrial or municipal effluents (Tornes and Brigham, 1993). These changes may be subject to complex interactions that vary over time and location.

Nitrate is the primary form of dissolved nitrogen in streams and groundwater (Dubrovsky and others, 2010). Other forms of nitrogen, such as nitrite and ammonia, readily oxidize to form nitrate, which readily moves through soil (Hem, 1985). Nitrate-plus-nitrite concentrations are commonly used to represent nitrate because nitrite concentrations are much smaller than nitrate concentrations. Trends in nitrate plus nitrate can be linked to point source pollution, such as industrial or municipal effluent, subsurface drainage tiles, and fertilizer application. Subsurface drainage tiles are a relatively new addition to artificial drainage in the Red River Basin, but installation has increased rapidly, especially in the upper Red River subbasin during the recent (2000-15) period (University of Minnesota Extension, 2019). Nitrogen export in streams with subsurface drainage can be nearly three times larger than in other agricultural streams (Capel and others, 2018).
Nitrate-plus-nitrite concentrations are affected by complex processes, making it possible to see changes in tributaries that are not necessarily reflected in the main stem. Median concentrations of nitrate plus nitrite ranged from $0.06 \mathrm{mg} / \mathrm{L}$ for Roseau River (site 27) and Sheyenne River below Balhill Dam (site 9) to $0.81 \mathrm{mg} / \mathrm{L}$ for the Red River (site 6; table 2).

No consistent pattern of increasing or decreasing concentrations across the basin was observed for nitrate plus nitrite (table 3, figs. 8 and 9). Of the 31 sites with enough data for trend analysis, 16 had increasing concentrations, 6 of which were significant or mildly significant, and 15 had decreasing concentrations, 6 of which were significant or mildly significant (fig. 9A). All sites in the Sheyenne River subbasin had decreasing concentrations, two of which were significant or mildly significant decreases. Other than one site on the Pembina River (site 24), all sites with significant or mildly significant increasing concentrations were in the upper Red River subbasin. Increases in concentration in the upper Red River subbasin may be related to increased subsurface drainage. The largest increase in nitrate plus nitrite was for main-stem site 6 , where the FAGMC increased by almost $0.3 \mathrm{mg} / \mathrm{L}$. This site is immediately downstream from the urban area of Fargo, N. Dak., and concentrations for upstream sites were much lower and had trends of much smaller magnitude (fig. 9B); therefore, the large increase in FAGMC for site 6 probably reflects increases in localized sources of nitrogen in the Fargo area in addition to smaller increases from upstream tributaries. Likewise, the next main-stem site (site 15) also had a significant increase in FAGMC (from 0.59 to $0.75 \mathrm{mg} / \mathrm{L}$ ) in nitrate plus nitrite, but the FAGMC and magnitude of increase for that site were much smaller compared to site 6 , indicating that tributary inflows between sites 6 and 15 substantially reduced, but did not completely nullify the increase for site 6 . Likewise, for the next downstream main-stem site (site 20), the smaller FAGMC and magnitude of increase (from 0.43 to $0.52 \mathrm{mg} / \mathrm{L}$ ) reflected further dilution from intervening tributaries. One of those Minnesota tributaries (Red Lake River, site 19) is particularly large, with streamflow nearly equal to main-stem site 15 (U.S. Geological Survey, 2019), and site 19 generally had much lower concentrations compared to site 15 (more than 50 percent of the nitrate data for site 19 was censored). Therefore, local runoff from the Grand Forks, N. Dak., urban area may have contributed to the increased concentration in nitrate plus nitrite for site 20. Like site 20, main-stem sites 26 and 30 had nonsignificant increases in concentration of about the same magnitude as site 20, and the FAGMC at end of the trend period was only slightly less than the FAGMC of $0.52 \mathrm{mg} / \mathrm{L}$ for site 20 (fig. $9 B$ ), which is consistent with a small degree of dilution from intervening tributaries. However, for the most downstream main-stem site (33), there was negligible increase in the FAGMC despite little dilution from tributary sites 30 and 33 and the FAGMC was substantially higher compared to site 31 . The smaller (yet also nonsignificant) increase for site 33 is probably due to uncertainty in the 


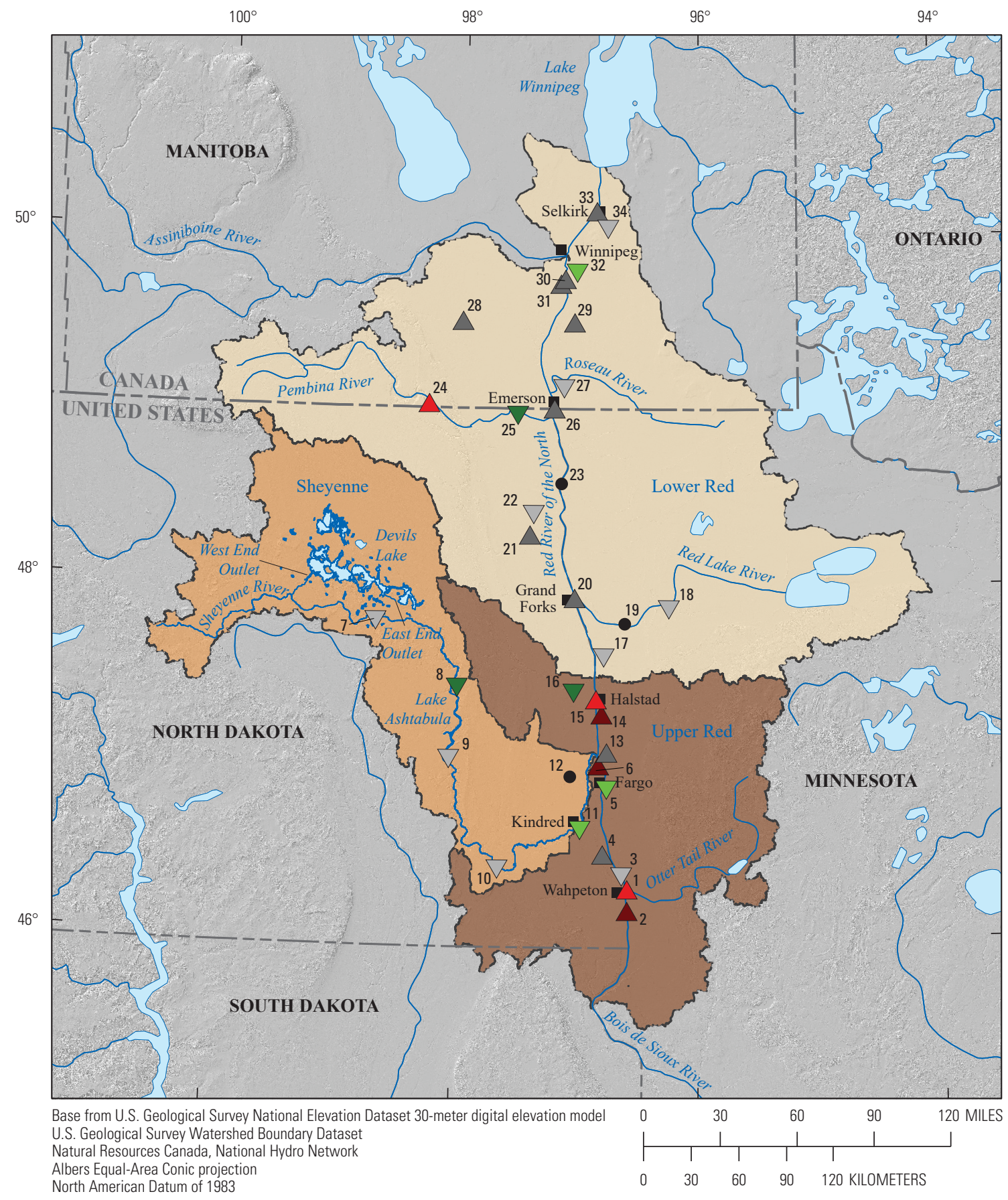

EXPLANATION

\begin{tabular}{|lllll}
\hline Subbasins & 12 & Too few data and site number & Nonsignificant decrease and site number \\
\hline & Lower Red & 14 & Significant increase and site number & Mildly significant decrease and site number \\
\hline Sheyenne & 24 & Mildly significant increase and site number & 16 & Significant decrease and site number \\
\hline Upper Red & 21 & Nonsignificant increase and site number & \\
\hline
\end{tabular}

Figure 8. Direction and significance of trends in nitrate-plus-nitrite concentration evaluated for the recent period 2000-15 at selected sites in the Red River of the North Basin. 


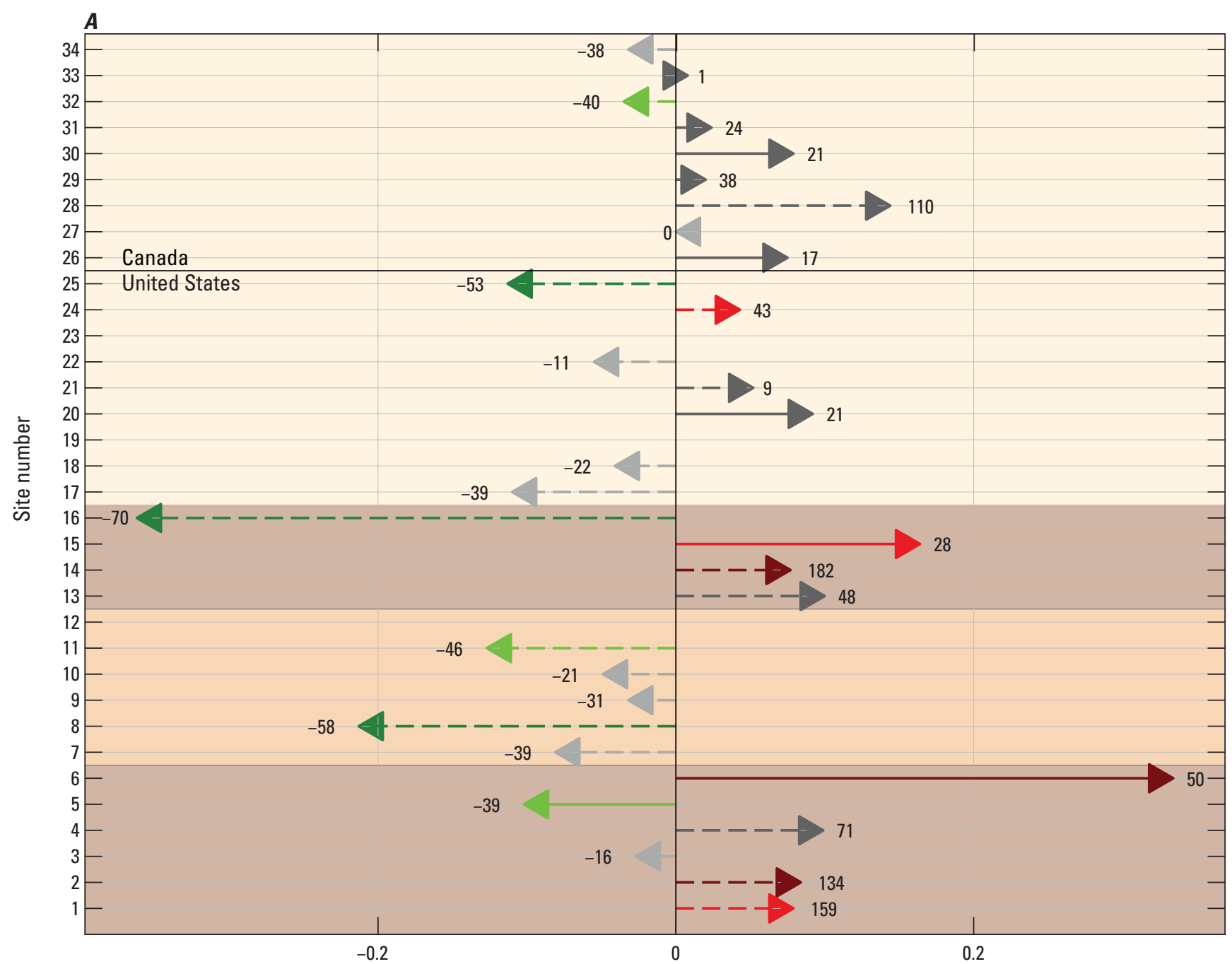

Change in annual flow-averaged geometric mean nitrate-plus-nitrite concentration from first year to last year of trend period (2000-15), in milligrams per liter

\section{EXPLANATION}

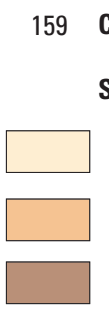

Change in percent
Subbasins
Lower Red
Sheyenne
Upper Red

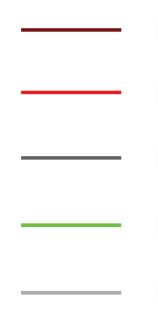

Main-stem site
Main-stem site
Main-stem site
Main-stem site
Main-stem site
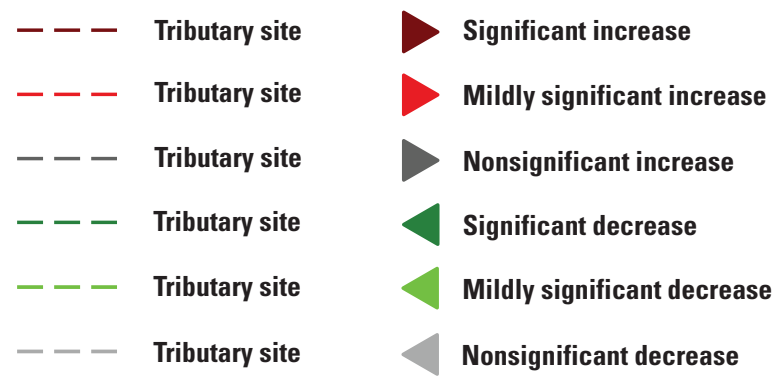

Figure 9. Trends in nitrate-plus-nitrite concentration evaluated for the recent period 2000-15 at selected sites in the Red River of the North Basin. $A$, change in annual flow-averaged geometric mean concentration from first year to last year of the trend period; $B$, annual flow-averaged geometric mean concentration from first year to last year of the trend period. [Shading corresponds to the subbasins in figure 8] 


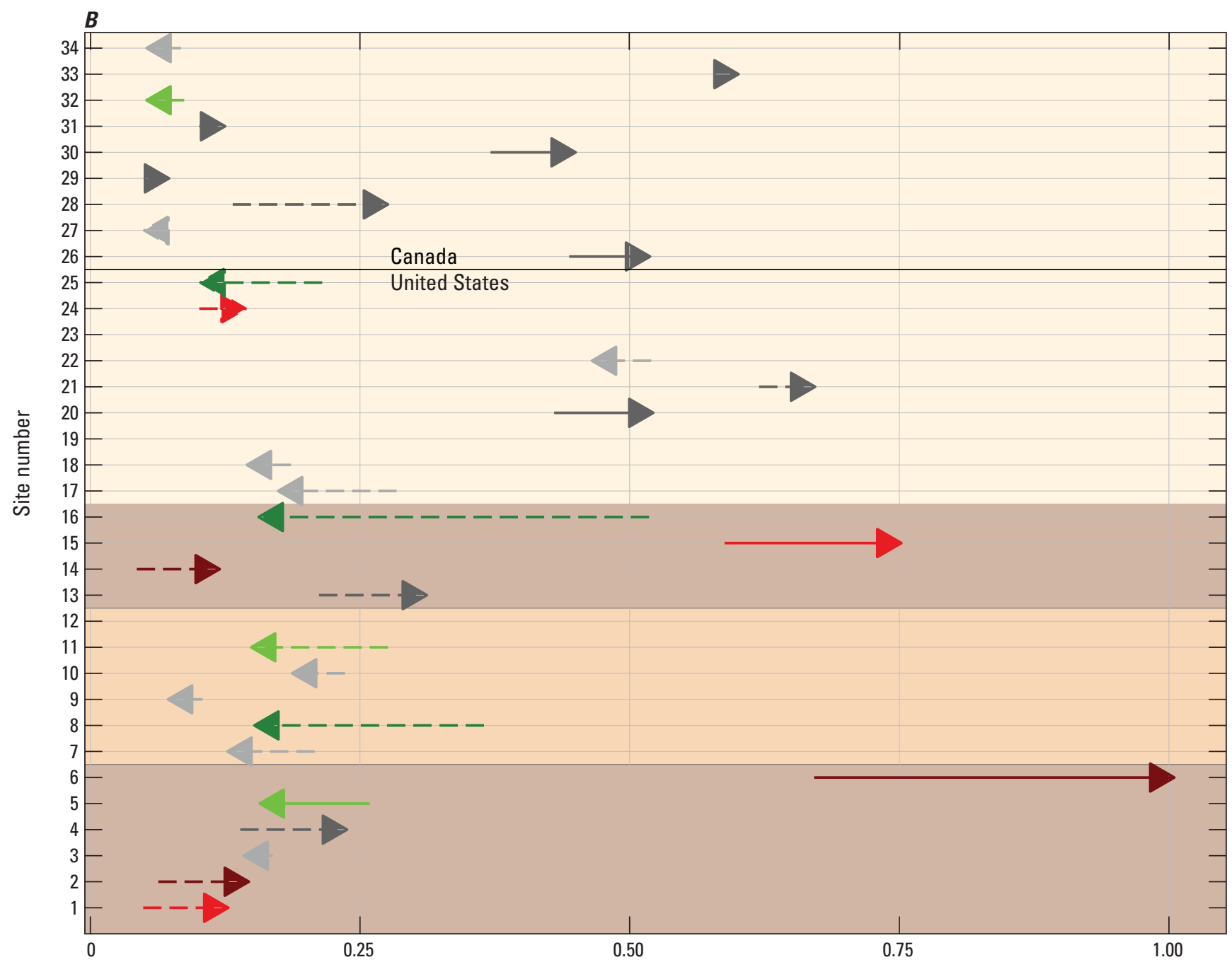

Annual flow-averaged geometric mean nitrate-plus-nitrite concentration from first year to last year of trend period (2000-15), in milligrams per liter

\section{EXPLANATION}

\begin{tabular}{|c|c|c|c|c|}
\hline Subbasins & Main-stem site & --- & Tributary site & Significant increase \\
\hline Lower Red & Main-stem site & --- & Tributary site & Mildly significant increase \\
\hline Sheyenne & Main-stem site & --- & Tributary site & Nonsignificant increase \\
\hline Upper Red & Main-stem site & --- & Tributary site & Significant decrease \\
\hline & Main-stem site & --- & Tributary site & Mildly significant decrease \\
\hline & & --- & Tributary site & Nonsignificant decrease \\
\hline
\end{tabular}

Figure 9. Trends in nitrate-plus-nitrite concentration evaluated for the recent period 2000-15 at selected sites in the Red River of the North Basin. $A$, change in annual flow-averaged geometric mean concentration from first year to last year of the trend period; $B$, annual flow-averaged geometric mean concentration from first year to last year of the trend period. [Shading corresponds to the subbasins in figure 8]-Continued 
trend magnitude for that site, and higher FAGMC for site 33 at the end of the period was probably due to local runoff from the urban area of Winnipeg.

Overall, the recent increases in nitrate-plus-nitrite concentration in some upstream tributaries and in the main-stem Red River downstream from Fargo, N. Dak., coupled with smaller less significant and mostly decreasing concentrations for most sites in the Sheyenne and Lower Red River subbasins likely indicate that increases are related to subsurface drainage in the Upper Red River subbasin or localized runoff from urban, industrial, or agricultural sources of nitrogen along the main-stem Red River. Decreasing (though mostly nonsignificant) concentrations for many of the tributary sites may be due to decreasing agricultural use or targeted application rates and times of nitrogen fertilizer.

Total nitrogen is the summation of the particulate and dissolved forms of nitrogen including nitrate, nitrite, ammonia, and organic nitrogen (Dubrovsky and others, 2010). Organic nitrogen is higher in the basin than in other parts of the country because it adheres to the fine-grained soils of the basin (Stoner and others, 1993); thus, total nitrogen concentration in the basin tends to be high relative to nitrate-plus-nitrite concentration (table 2). The average median nitrate-plus-nitrite concentration for all sites $(0.29 \mathrm{mg} / \mathrm{L})$ is about 20 percent of the average median total nitrogen concentration for all sites $(1.35 \mathrm{mg} / \mathrm{L})$. Trends in total nitrogen are affected by increased sediment delivery to streams as well as changes to point sources and agricultural activities. Median total nitrogen concentrations ranged from $0.70 \mathrm{mg} / \mathrm{L}$ for the Pembina River (site 25) to $2.17 \mathrm{mg} / \mathrm{L}$ for the Red River (site 33; table 2).

Like nitrate-plus-nitrite concentrations, trends in total nitrogen concentrations were mixed but more were nonsignificant (table 3, figs. 10 and 11). Of the 32 sites with enough data for trend analysis of total nitrogen concentrations, about half had increasing concentrations and half had decreasing concentrations, and only 8 sites had significant or mildly significant trends ( 2 increasing and 6 decreasing, fig. 11A). Also, like nitrate plus nitrite, sites in the Sheyenne River subbasin had decreasing total nitrogen concentrations, and for three of the five sites, the decreases were significant or mildly significant (fig. 11A). However, unlike nitrate plus nitrite, there were no significant or mildly significant upward trends in total nitrogen concentration for any main-stem or upper Red tributary sites (compared with 5 such trends for nitrate plus nitrite; fig. 9A). Although decreases in the concentration of particulate nitrogen may be offsetting increases in dissolved nitrogen (mostly nitrate) for some of these sites, it is more likely that these differences in trend results between total nitrogen and nitrate plus nitrite are due to high uncertainty in the total nitrogen trends. For example, the largest discrepancy was for main-stem site 6, for which the FAGMC of $2.28 \mathrm{mg} / \mathrm{L}$ for total nitrogen (table 3, fig. $11 B$ ) remained virtually constant compared to a highly significant increase of about $0.3 \mathrm{mg} / \mathrm{L}$ in FAGMC for nitrate plus nitrite (from about 0.7 to $1.0 \mathrm{mg} / \mathrm{L}$; table 3 ). An increase of $0.3 \mathrm{mg} / \mathrm{L}$ corresponds to only about 12 percent of the total nitrogen concentration, making an increase of that magnitude difficult to detect given the available data. The next downstream main-stem site (site 15) did not have enough data for estimating the total nitrogen trend, but for the remaining mainstem sites (sites 20,26,30, and 33), the total nitrogen trends (fig. 11B) were similar to nitrate-plus-nitrite trends (fig. 9B). Using the proposed WQO of $1.15 \mathrm{mg} / \mathrm{L}$ set for the binational site for reference, by the end of the recent trend period (2015) across the basin, the annual FAGMC of total nitrogen was greater than $1.15 \mathrm{mg} / \mathrm{L}$ for 23 of the 31 sites analyzed, including all main-stem sites except site 5 (fig. 11B).

Total phosphorus is usually bound to sediment and includes particulate organic phosphorus and dissolved forms of phosphorus such as orthophosphate (Dubrovsky and others, 2010). Potential factors affecting phosphorus concentrations in the basin include soil erosion, animal waste, fertilizer application, and industrial and municipal effluent. Median total phosphorus concentrations ranged from $0.07 \mathrm{mg} / \mathrm{L}$ for the Red Lake River (site 19) to $0.49 \mathrm{mg} / \mathrm{L}$ for the La Salle River (not shown) (site 31; table 2).

Compared to total nitrogen, there was a much more consistent pattern in the total phosphorus trends across the basin in which phosphorus concentrations were decreasing in the Sheyenne and upper Red River subbasins and increasing in the lower Red River subbasin (table 3, figs. 12 and 13). Of the 32 sites available for trend analysis of total phosphorus concentrations, 23 sites had decreasing concentrations, 15 of which were in the Sheyenne and upper Red River subbasins (fig. 13A). Furthermore, out of nine sites with significant or mildly significant decreasing concentrations, seven were in the Sheyenne and upper Red River subbasins and only two were in the lower Red River subbasin. In contrast, eight of the nine sites with increasing concentrations, including all five significant or mildly significant increasing concentrations, were in the lower Red River subbasin. Total phosphorus trends for the eight main-stem sites analyzed were consistent with trends for the tributary sites upstream from them. All four main-stem sites in the upper Red River subbasin (sites 3, 5, 6, and 15) had decreasing concentrations, three of which were significant or mildly significant, and all four main-stem sites in the lower Red River subbasin (sites 20, 26, 30, and 33) had increasing concentrations, two of which were significant or mildly significant (figs. 13A). Thus, in the Sheyenne and upper Red River subbasins, changes affecting total phosphorus concentrations during 2000-15 resulted in decreasing total phosphorus concentrations, whereas changes in the lower Red River subbasin resulted in increasing total phosphorus concentrations. With respect to the trend magnitudes, some of these increases in the lower Red River subbasin were substantial; for example, for the binational site (site 26), the annual FAGMC of total phosphorus increased by $0.06 \mathrm{mg} / \mathrm{L}$ or 27 percent from 2000 to 2015 and for Manitoba tributary site 31, the FAGMC increased by $0.09 \mathrm{mg} / \mathrm{L}$ or 23 percent (fig. 13A). Conversely, for mainstem site 15 , the total phosphorus FAGMC decreased by $0.10 \mathrm{mg} / \mathrm{L}$ or 24 percent. Using the proposed total phosphorus WQO of $0.15 \mathrm{mg} / \mathrm{L}$ set for the binational site as a reference, by 2015 , the FAGMC of total phosphorus was greater than 


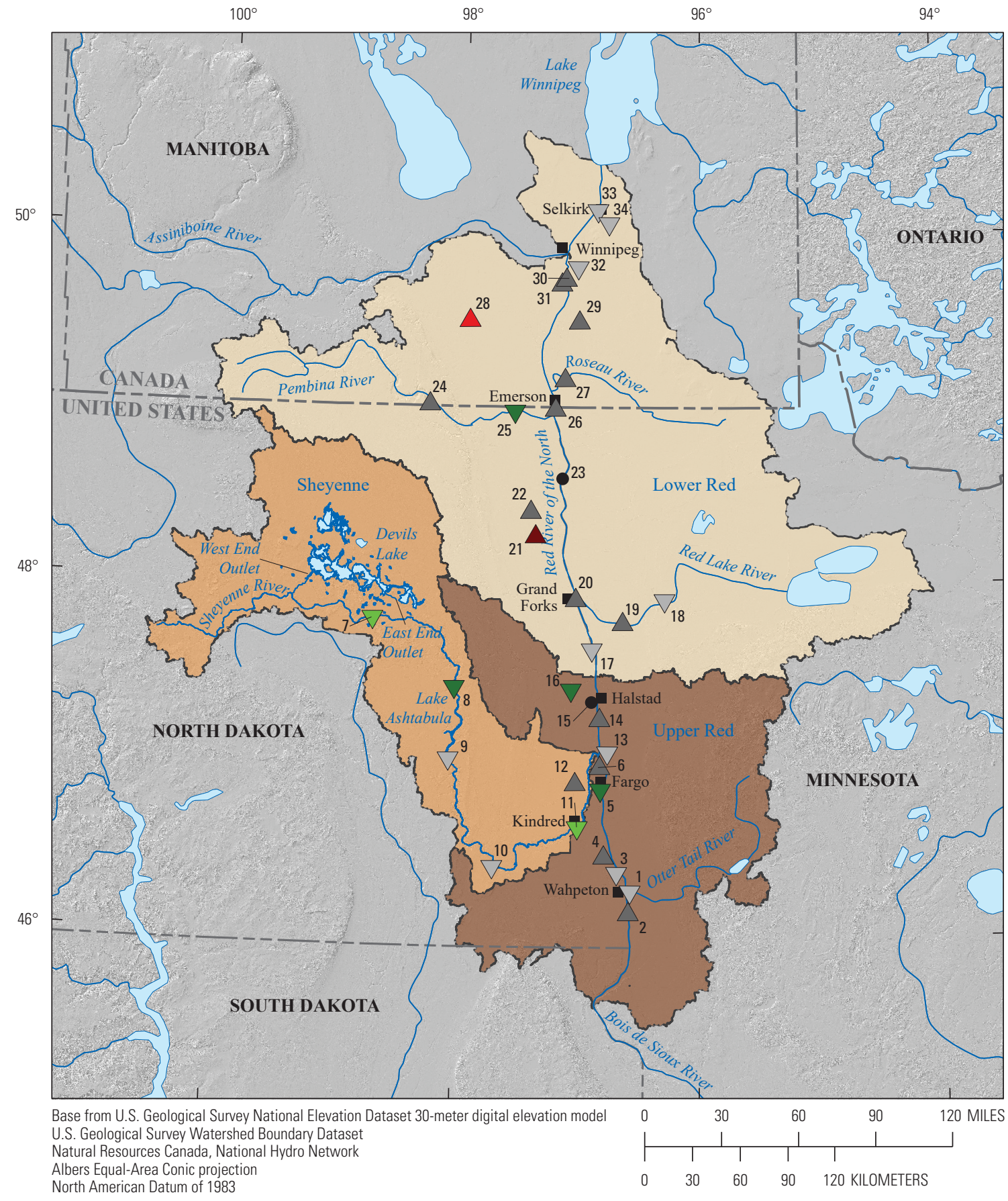

\section{EXPLANATION}

\begin{tabular}{|c|c|c|}
\hline Subbasins & Too few data and site number & Nonsignificant decrease and site number \\
\hline Lower Red & Significant increase and site number & Mildly significant decrease and site number \\
\hline Sheyenne & Mildly significant increase and site number & Significant decrease and site number \\
\hline Upper Red & Nonsignificant increase and site number & \\
\hline
\end{tabular}

Figure 10. Direction and significance of trends in total nitrogen concentration evaluated for the recent period 2000-15 at selected sites in the Red River of the North Basin. 


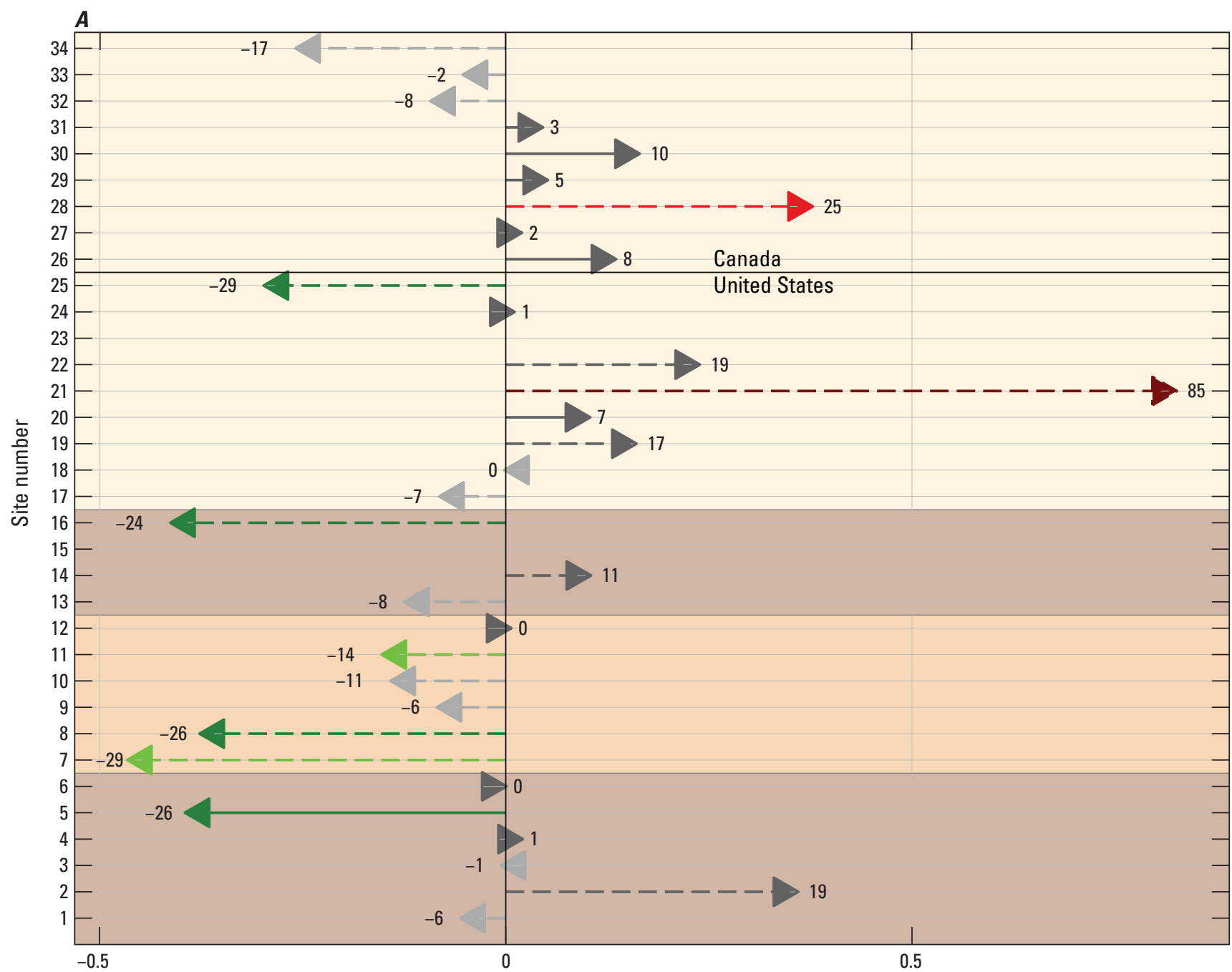

Change in annual flow-averaged geometric mean total nitrogen concentration from first year to last year of trend period (2000-15), in milligrams per liter

\section{EXPLANATION}

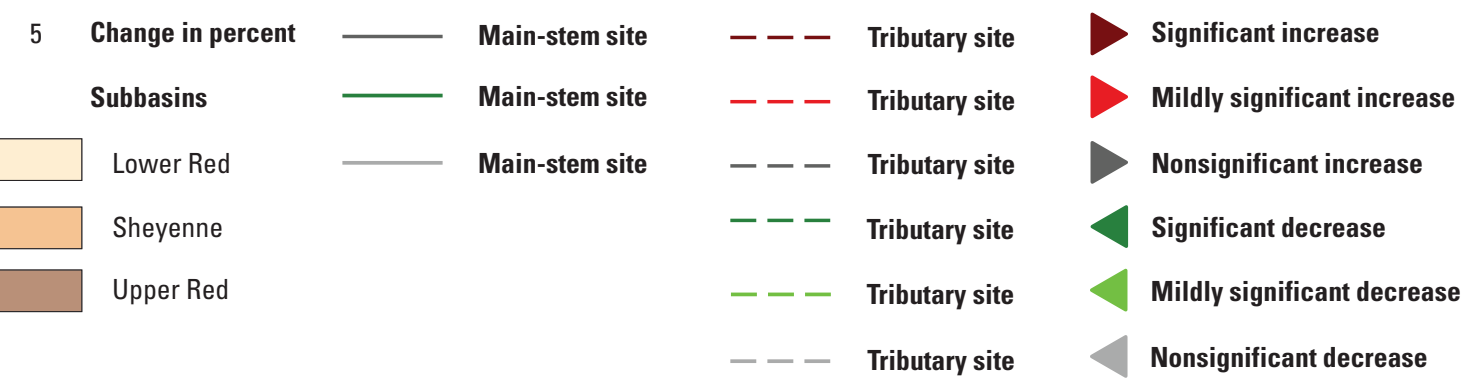

Figure 11. Trends in total nitrogen concentration evaluated for the recent period 2000-15 at selected sites in the Red River of the North Basin. $A$, change in annual flow-averaged geometric mean concentration from first year to last year of the trend period; $B$, annual flow-averaged geometric mean concentration from first year to last year of the trend period. [Shading corresponds to the subbasins in figure 10] 


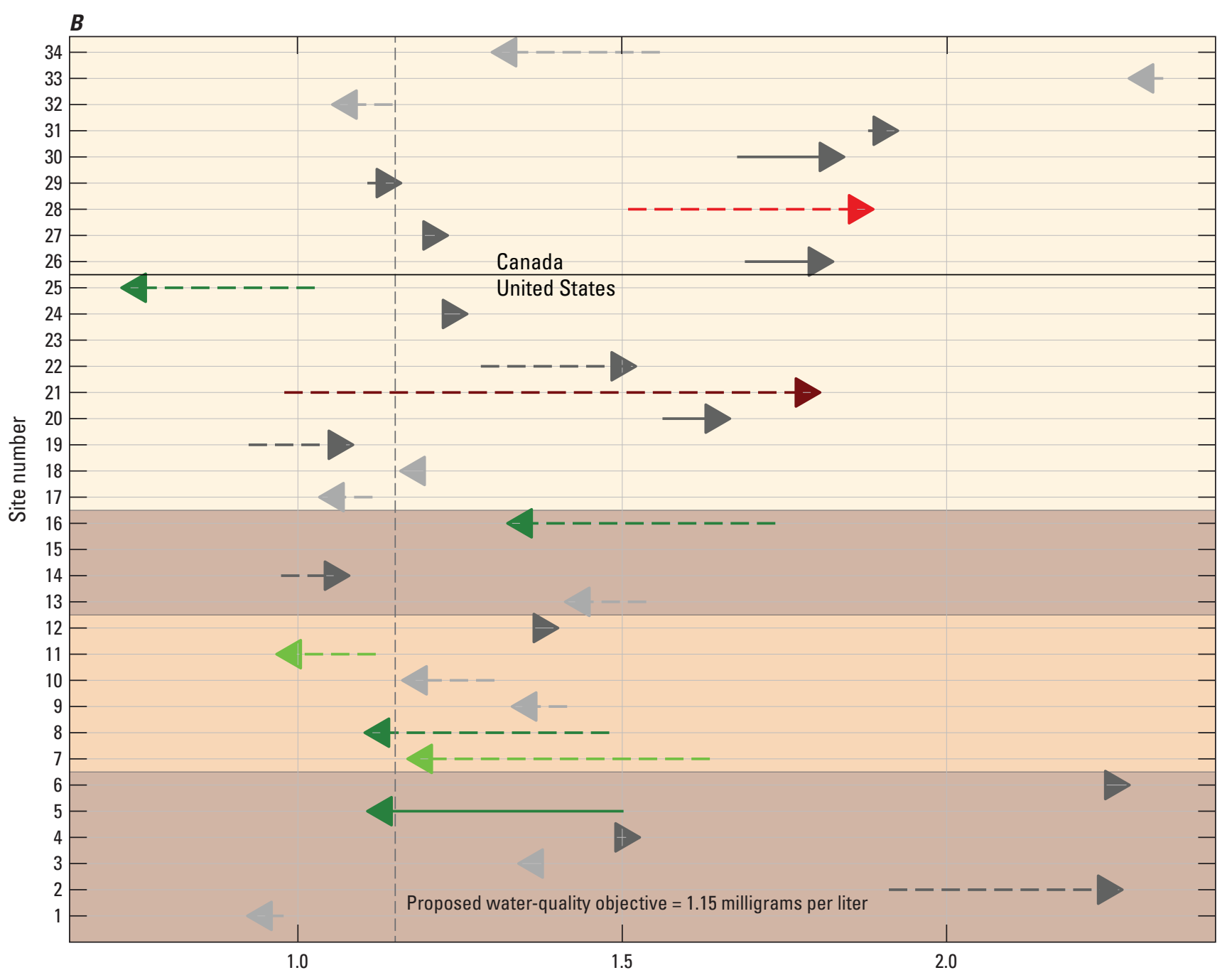

Annual flow-averaged geometric mean total nitrogen concentration from first year to last year of trend period (2000-15), in milligrams per liter

\section{EXPLANATION}

\begin{tabular}{|c|c|c|c|c|}
\hline Subbasins & Main-stem site & --- & Tributary site & Significant increase \\
\hline Lower Red & Main-stem site & --- & Tributary site & Mildly significant increase \\
\hline Sheyenne & Main-stem site & --- & Tributary site & Nonsignificant increase \\
\hline Upper Red & & --- & Tributary site & Significant decrease \\
\hline & & --- & Tributary site & Mildly significant decrease \\
\hline & & --- & Tributary site & Nonsignificant decrease \\
\hline
\end{tabular}

Figure 11. Trends in total nitrogen concentration evaluated for the recent period 2000-15 at selected sites in the Red River of the North Basin. $A$, change in annual flow-averaged geometric mean concentration from first year to last year of the trend period; $B$, annual flow-averaged geometric mean concentration from first year to last year of the trend period. [Shading corresponds to the subbasins in figure 10]_Continued 


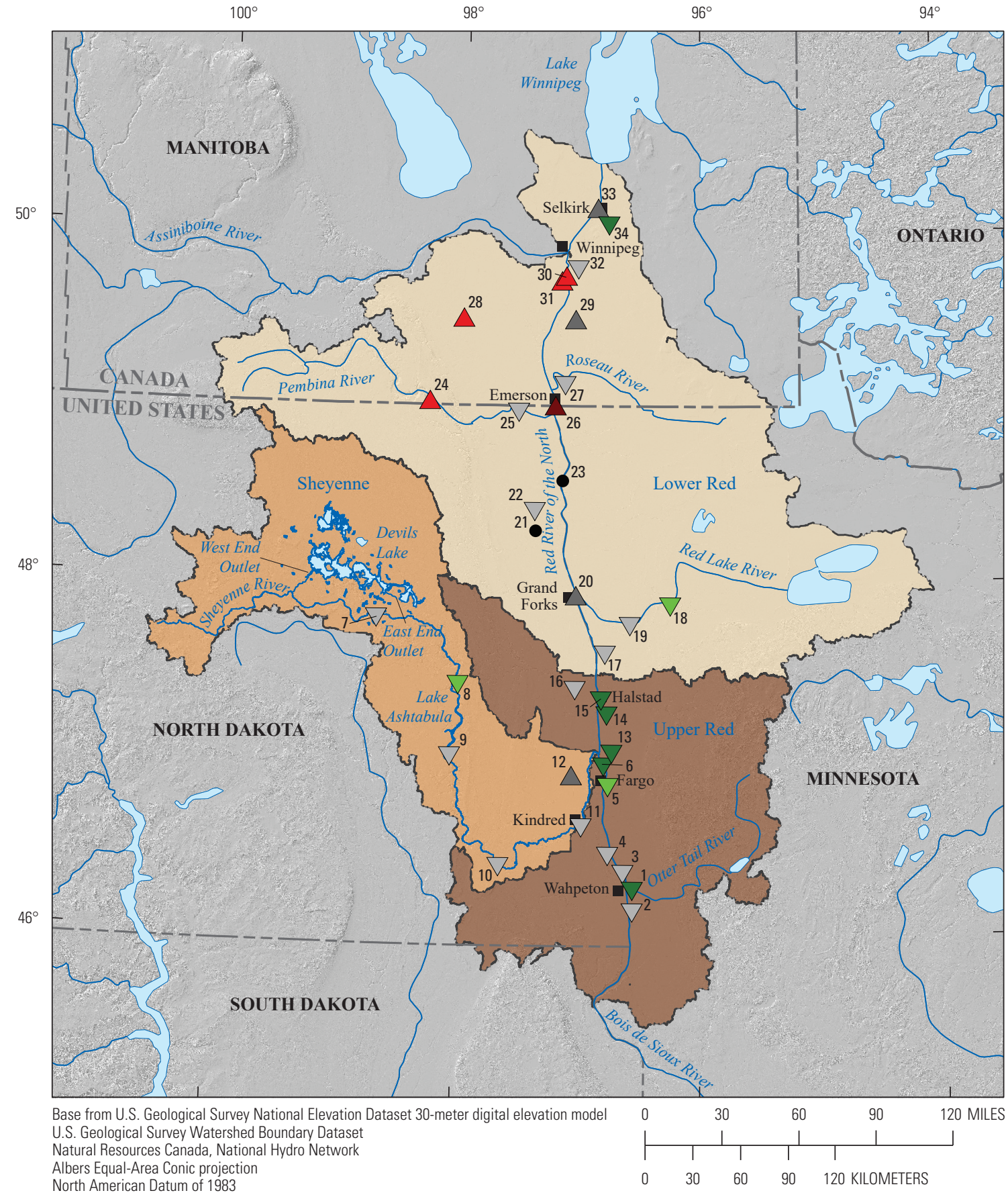

EXPLANATION

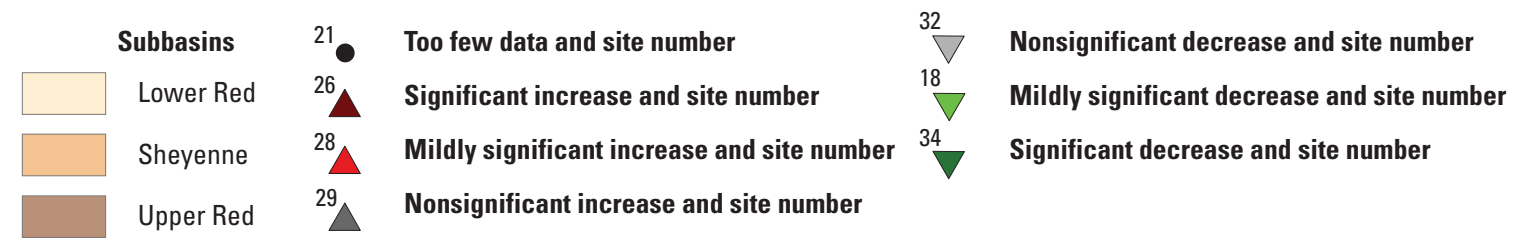

Figure 12. Direction and significance of trends in total phosphorus concentration evaluated for the recent period 2000-15 at selected sites in the Red River of the North Basin. 


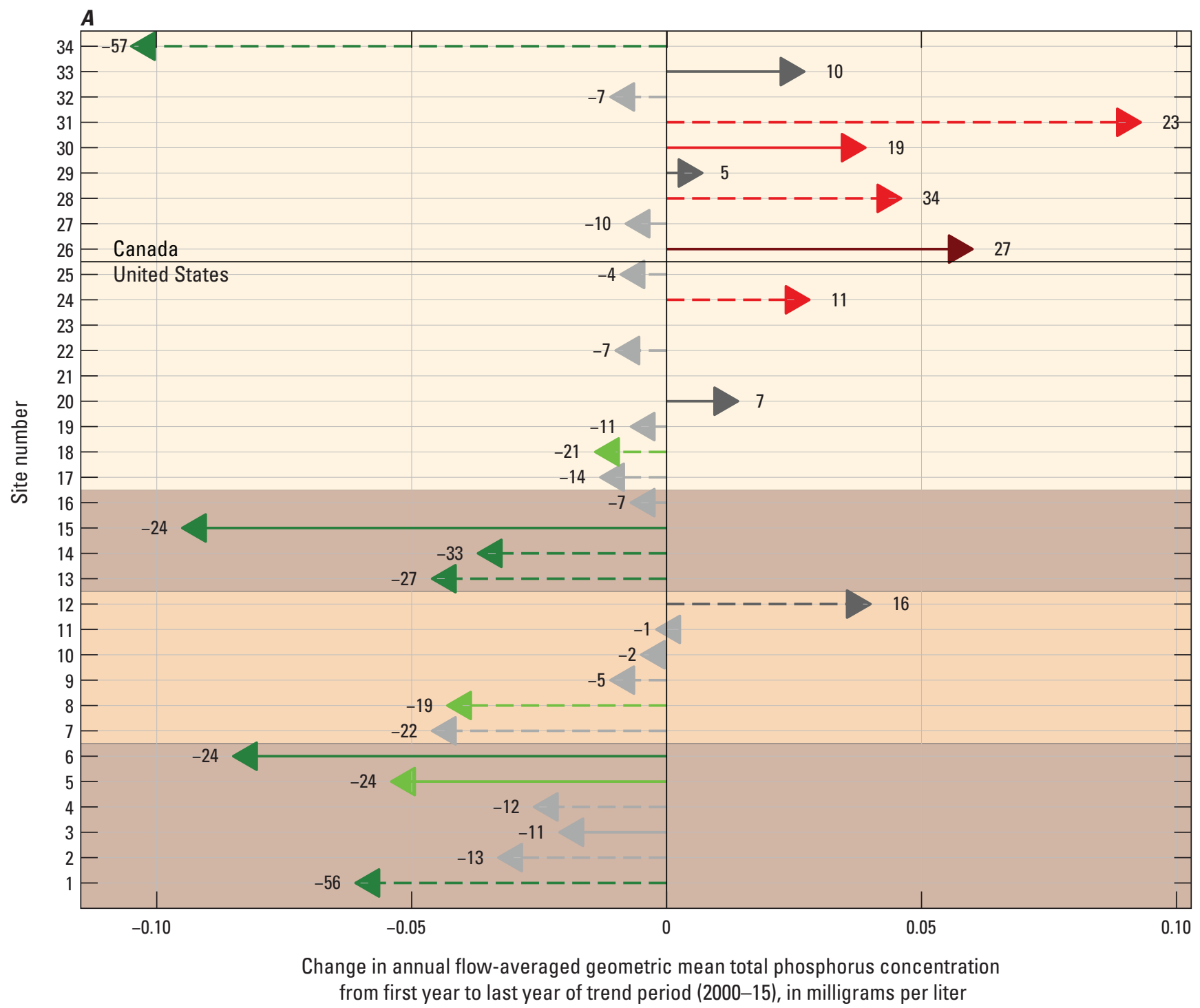

\section{EXPLANATION}

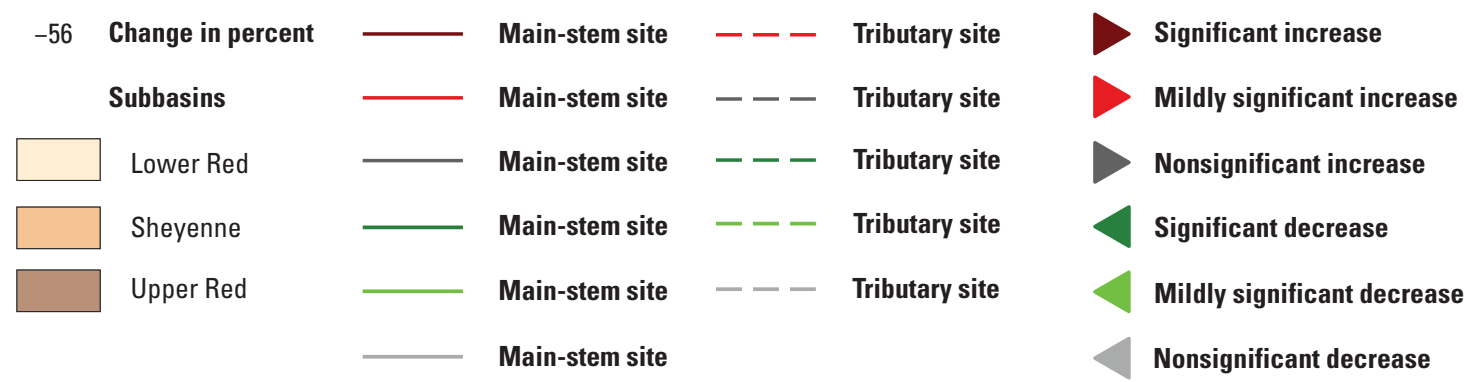

Figure 13. Trends in total phosphorus concentration evaluated for the recent period 2000-15 at selected sites in the Red River of the North Basin. $A$, change in annual flow-averaged geometric mean concentration from first year to last year of the trend period; $B$, annual flow-averaged geometric mean concentration from first year to last year of the trend period. [Shading corresponds to the subbasins in figure 12] 


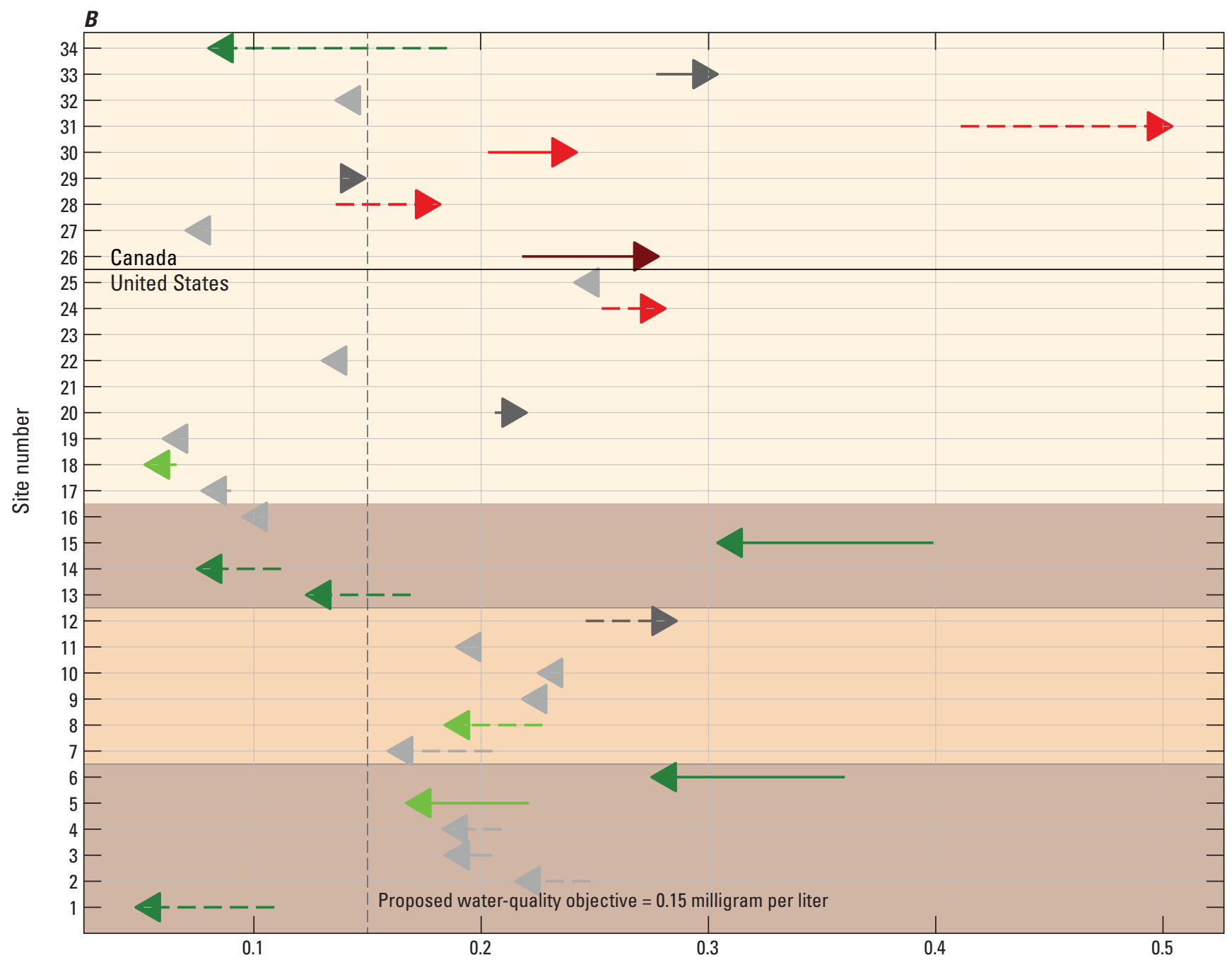

Annual flow-averaged geometric mean total phosphorus concentration from first year to last year of trend period (2000-15), in milligrams per liter

\section{EXPLANATION}

\begin{tabular}{|c|c|c|c|c|}
\hline Subbasins & Main-stem site & --- & Tributary site & Significant increase \\
\hline Lower Red & Main-stem site & --- & Tributary site & Mildly significant increase \\
\hline Sheyenne & Main-stem site & --- & Tributary site & Nonsignificant increase \\
\hline Upper Red & Main-stem site & --- & Tributary site & Significant decrease \\
\hline & & --- & Tributary site & Mildly significant decrease \\
\hline
\end{tabular}

Figure 13. Trends in total phosphorus concentration evaluated for the recent period 2000-15 at selected sites in the Red River of the North Basin. $A$, change in annual flow-averaged geometric mean concentration from first year to last year of the trend period; $B$, annual flow-averaged geometric mean concentration from first year to last year of the trend period. [Shading corresponds to the subbasins in figure 12]—Continued 
$0.15 \mathrm{mg} / \mathrm{L}$ for 20 of the 32 sites analyzed, including all mainstem sites (fig. 13B). The sharp contrast between the trends for the upper and lower Red River subbasins is clearly indicated by comparing the FAGMC for main-stem sites 15 and 26. In 2000, the FAGMC for site $15(0.40 \mathrm{mg} / \mathrm{L})$ was almost twice as high as the FAGMC for site $26(0.22 \mathrm{mg} / \mathrm{L})$, but in 2015 , the FAGMC for site $15(0.30 \mathrm{mg} / \mathrm{L})$ was only about 10 percent higher than the FAGMC for site $26(0.28 \mathrm{mg} / \mathrm{L}$; fig. 13B). Like total nitrogen, decreasing use of phosphorus fertilizer combined with targeted application rates in the upper basin may be contributing to decreasing concentrations of total phosphorus. In addition, the relatively large magnitudes of the decreases in FAGMC for the two main-stem sites immediately downstream from the Fargo area (sites 6 and 15), in relation to the smaller trends for the upstream tributaries (fig. 13B), may signify a reduction in urban or industrial point sources of phosphorus in that reach during the recent period. Determining potential causes for increasing phosphorus concentrations in the lower basin requires further investigation.

\section{Total Suspended Solids}

Suspended sediment in surface water is the particulate matter that consists of soil and rock particles eroded from the landscape. Sediment is transported in the water column or settles to the streambed. Two laboratory-analytical methods are used to quantify the concentration of suspended particulate matter in surface water: suspended-sediment concentration and total suspended solids. Total suspended solids analysis was originally designed for wastewater effluent but has been extended operationally to include natural water (Gray and others, 2000). Suspended-sediment concentration analytical methods measure all the sediment and the mass of the watersediment sample, whereas methods for total suspended solids only use an aliquot of the original sample for analysis. Total suspended solids concentrations are used interchangeably with suspended-sediment concentration, but when solidphase material, especially sand, becomes more concentrated, suspended-sediment concentration is more reliable (Gray and others, 2000). Total suspended solids were used for the current study because data were available for most sites across the basin. But, depending on the site, variability in the concentrations can be large, making trends more difficult to detect and likely less accurate. Median total suspended solids concentrations ranged from $7 \mathrm{mg} / \mathrm{L}$ at Clearwater River (not shown) (site 18) to $144 \mathrm{mg} / \mathrm{L}$ for the binational site (site 26, table 2). Trends in total suspended solids are affected by human activities that alter the amount of sediment washed off the landscape: changes in tillage practices, changes in CRP acreage, and large-scale shifts in crop types (Dubrovsky and others, 2010).

Trends in total suspended solids concentrations were mixed and highly variable (table 3, figs. 14 and 15). Slightly more sites had increasing total suspended solids concentrations than decreasing concentrations. Of the 30 sites available for trend analysis of total suspended solids concentrations, 18 sites had increasing concentrations, but only 4 of the increases were significant or mildly significant (fig. 15A). Conversely, 12 sites had decreasing concentrations, and 8 of the decreases were significant or mildly significant decreases (fig. 15A). Sites in the Sheyenne River subbasin all had increasing concentrations, but only one of the increases (site 8) was significant. Of the eight significant or mildly significant decreasing concentrations, six were for North Dakota and Minnesota tributary sites downstream from the Sheyenne River subbasin and another was for a Manitoba tributary. Trends for the main-stem sites were consistent with the mixed and variable trends for tributary sites. The only significant or mildly significant trends for the main-stem sites were a mildly significant downward trend for site 5 and a mildly significant upward trend for site 33. The large number of nonsignificant trends and the variable trend directions and magnitudes may be related to high variability in concentrations because of the analytical method for total suspended solids and the high degree of flow-related variability making it more difficult to detect concentration trends.

\section{Historical Water-Quality Trends}

Water-quality trends were analyzed for the historical period (1970-2015) using water-quality and streamflow data from 1970 to 2017 for a major Minnesota tributary (Red Lake River, site 19), a major North Dakota tributary (Sheyenne River, site 11) and three main-stem sites: 15, 26, and 33. Trends in sulfate, total dissolved solids, nitrate-plusnitrite, and total phosphorus concentrations were analyzed for all sites except for the Minnesota tributary (site 19). For that tributary site, total phosphorus was the only constituent with enough data over the historical period to analyze (enough samples were available for nitrate plus nitrite, but there were too many censored values). Depending on data availability, either a two-period or three-period trend model was used, where the last period (2000-15) coincided with the recent period trend analysis discussed previously. The twoperiod trend model consisted of two piecewise monotonic trends: 1985-2000 and 2000-15; the three-period trend model consisted of three piecewise monotonic trends: 1970-85, 1985-2000, and 2000-15. The three-period model was used for site 11 (sulfate, total dissolved solids, and total phosphorus), site 15 (total phosphorus), and site 33 (nitrate plus nitrite and total phosphorus), and the two-period model was used for all remaining cases (table 4). Trend results are reported in table 4 , in terms of percentage change and magnitude of change in the annual FAGMC from the first year to the last year of each trend period, and in figures showing the fitted trend in annual FAGMC over time. 


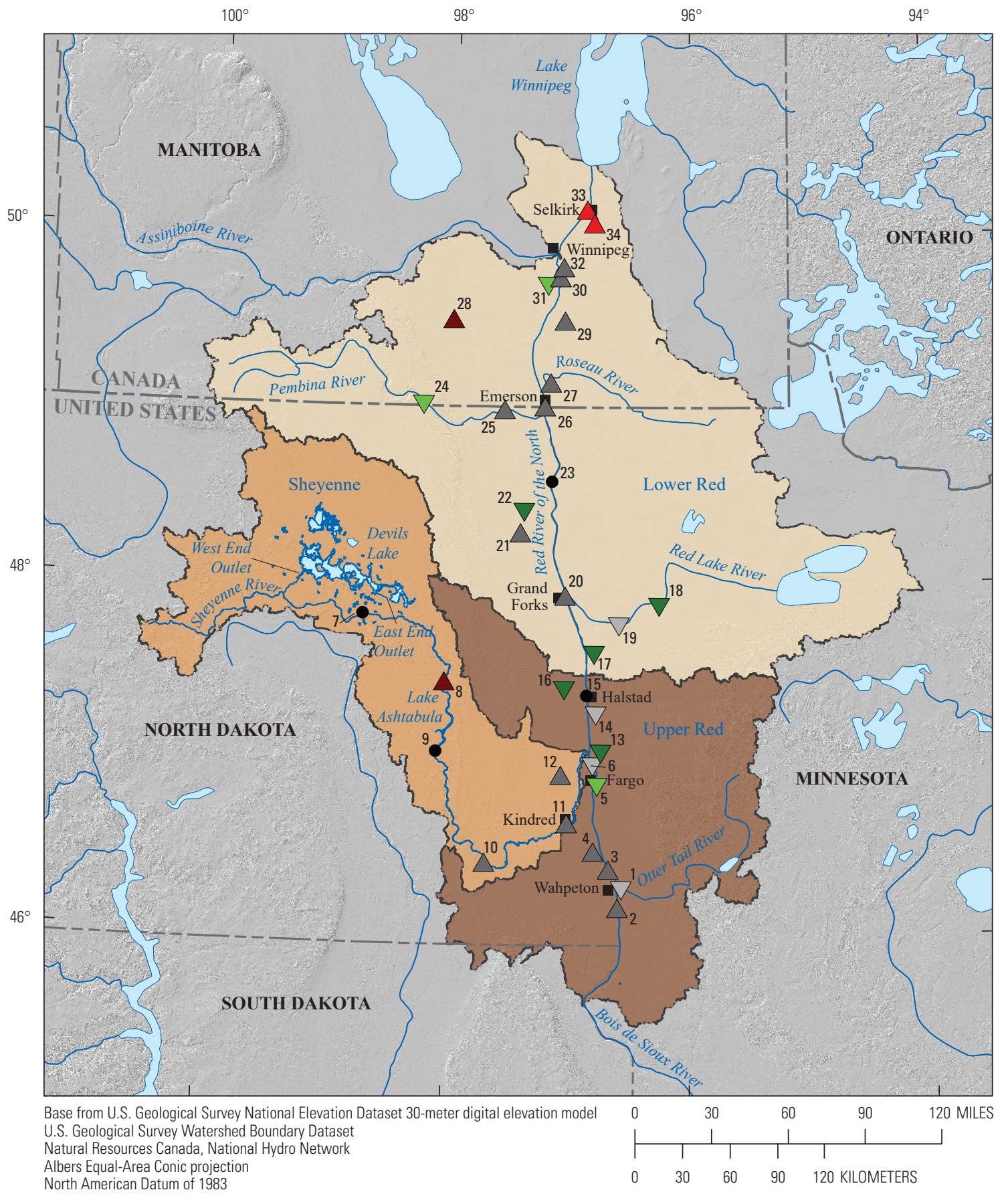

\section{EXPLANATION}

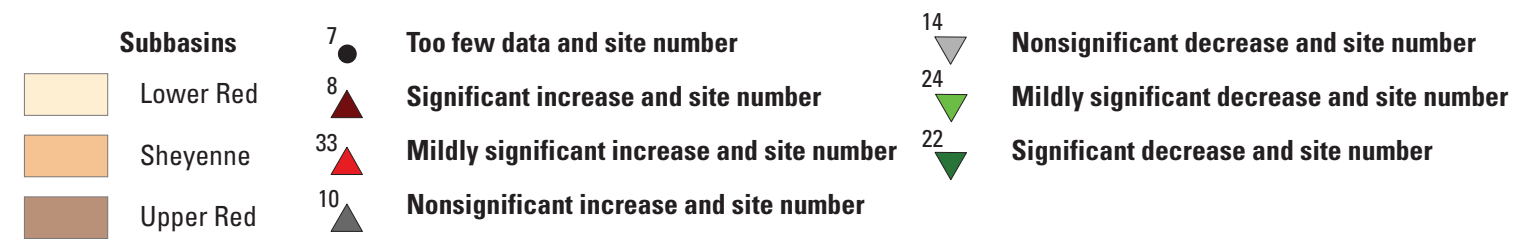

Figure 14. Direction and significance of trends in total suspended solids concentration evaluated for the recent period 2000-15 at selected sites in the Red River of the North Basin. 


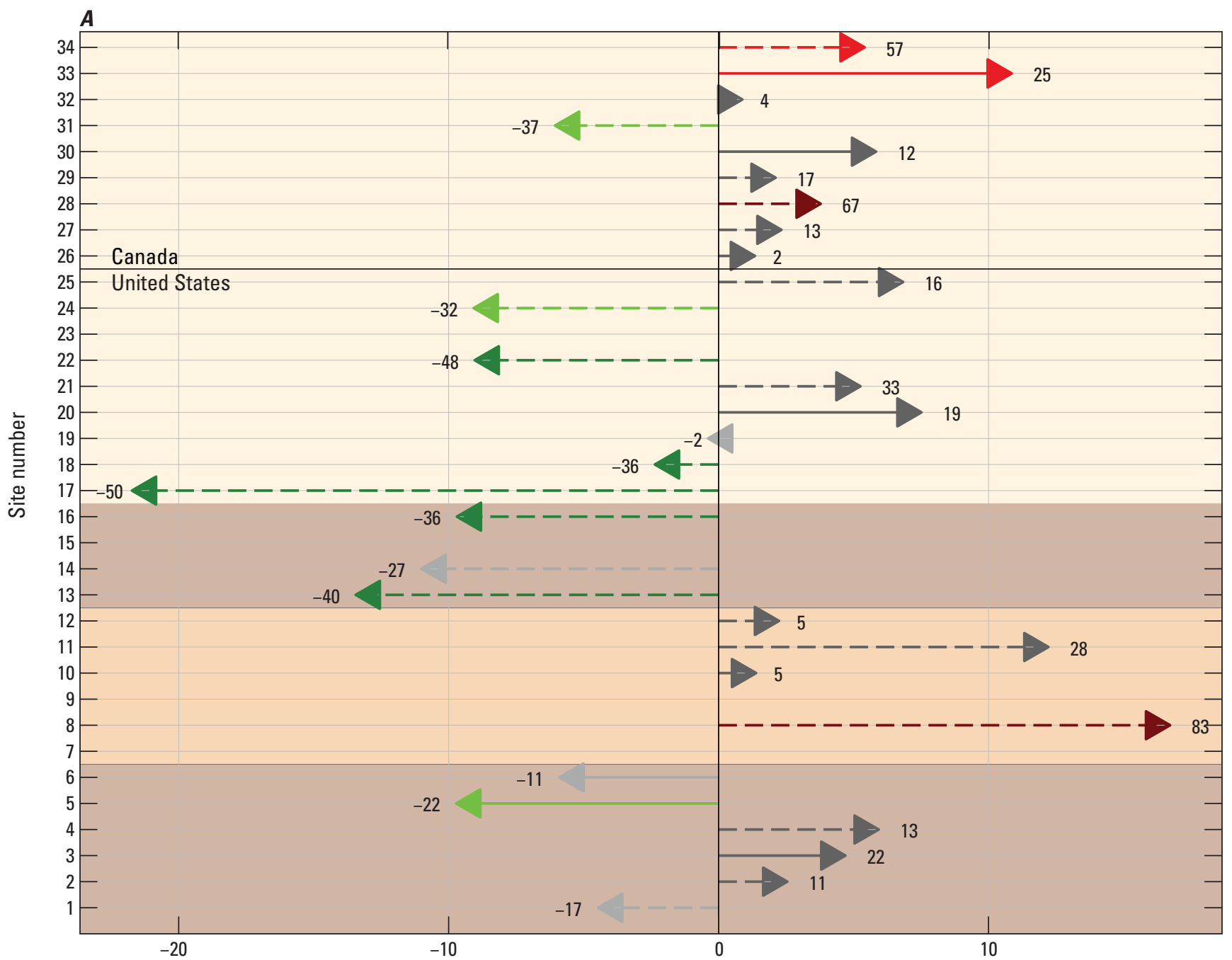

Change in annual flow-averaged geometric mean total suspended solids concentration from first year to last year of trend period (2000-15), in milligrams per liter

EXPLANATION

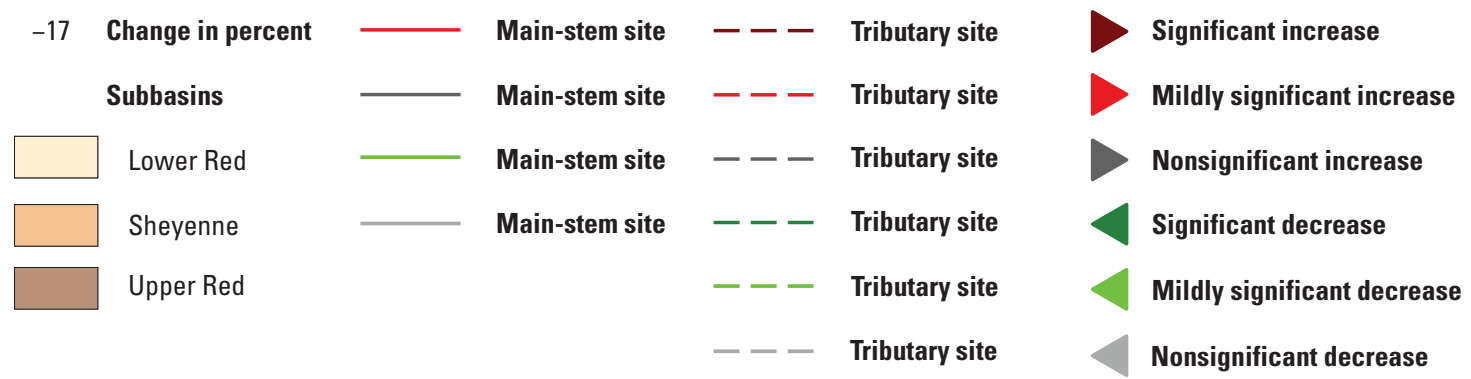

Figure 15. Trends in total suspended solids concentration evaluated for the recent period 2000-15 at selected sites in the Red River of the North Basin. $A$, change in annual flow-averaged geometric mean concentration from first year to last year of the trend period; $B$, annual flow-averaged geometric mean concentration from first year to last year of the trend period. [Shading corresponds to the subbasins in figure 14] 


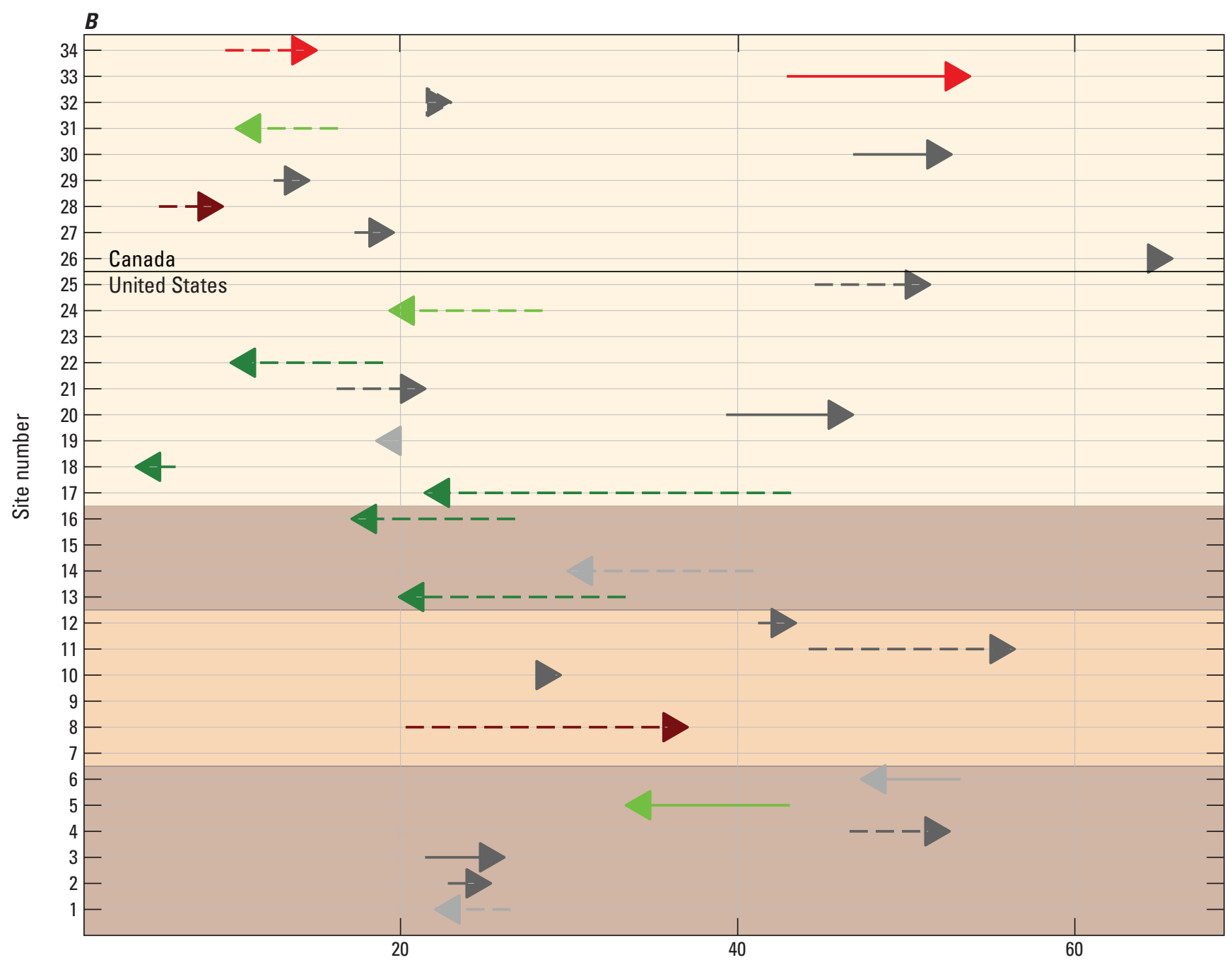

Annual flow-averaged geometric mean total suspended solids concentration from first year to last year of trend period (2000-15), in milligrams per liter

\section{EXPLANATION}

\begin{tabular}{|c|c|c|c|c|}
\hline Subbasins & Main-stem site & --- & Tributary site & Significant increase \\
\hline Lower Red & Main-stem site & --- & Tributary site & Mildly significant increase \\
\hline Sheyenne & Main-stem site & --- & Tributary site & Nonsignificant increase \\
\hline Upper Red & Main-stem site & --- & Tributary site & Significant decrease \\
\hline & & --- & Tributary site & Mildly significant decrease \\
\hline & & --- & Tributary site & Nonsignificant decrease \\
\hline
\end{tabular}

Figure 15. Trends in total suspended solids concentration evaluated for the recent period 2000-15 at selected sites in the Red River of the North Basin. $A$, change in annual flow-averaged geometric mean concentration from first year to last year of the trend period; $B$, annual flow-averaged geometric mean concentration from first year to last year of the trend period. [Shading corresponds to the subbasins in figure 14]—Continued 
Table 4. Summary of trend results evaluated for the historical period 1970-2015 based on data collected during 1970-2017 for sulfate, total dissolved solids, nitrate plus nitrite, and total phosphorus at selected sites in the Red River of the North Basin.

[p-value, probability; FAGMC, flow-averaged geometric mean concentration; USGS, U.S. Geological Survey; --, not applied; ND, North Dakota; MB, Manitoba; MN, Minnesota]

\begin{tabular}{|c|c|c|c|c|c|c|c|c|c|c|}
\hline $\begin{array}{l}\text { Site location } \\
\text { (fig. 1) }\end{array}$ & $\begin{array}{c}\text { Site } \\
\text { identifier }\end{array}$ & $\begin{array}{c}\text { Site } \\
\text { name }\end{array}$ & Trend model & $\begin{array}{l}\text { Trend } \\
\text { period }\end{array}$ & $\begin{array}{c}\text { Step } \\
\text { trend } \\
\text { applied }\end{array}$ & $p$-value & $\begin{array}{l}\text { Significance } \\
\text { level }\end{array}$ & 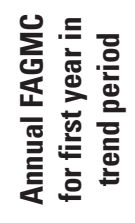 & 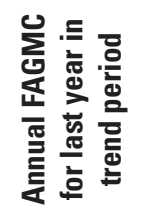 & 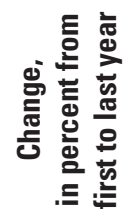 \\
\hline \multicolumn{11}{|c|}{ Sulfate, in milligrams per liter } \\
\hline \multirow[t]{3}{*}{11} & USGS-05059000 & $\begin{array}{c}\text { SHEYENNE RIVER } \\
\text { NEAR KINDRED }\end{array}$ & Three period & $1970-85$ & No & 0.0428 & Mildly significant & 164 & 138 & -16 \\
\hline & & & & $1985-2000$ & -- & 0.0000 & Significant & 138 & 225 & 63 \\
\hline & & & & $2000-15$ & -- & 0.0000 & Significant & 225 & 312 & 39 \\
\hline \multirow[t]{2}{*}{15} & USGS-05064500 & $\begin{array}{l}\text { RED RIVER OF THE } \\
\text { NORTH AT } \\
\text { HALSTAD, ND }\end{array}$ & Two period & $1985-2000$ & -- & 0.0083 & Significant & 101 & 129 & 27 \\
\hline & & & & $2000-15$ & -- & 0.0001 & Significant & 129 & 227 & 76 \\
\hline \multirow[t]{2}{*}{26} & MA05OC0001 & $\begin{array}{l}\text { RED RIVER AT } \\
\text { EMERSON, MB }\end{array}$ & Two period & $1985-2000$ & -- & 0.0000 & Significant & 73.0 & 118 & 62 \\
\hline & & & & $2000-15$ & -- & 0.0000 & Significant & 118 & 187 & 61 \\
\hline \multirow[t]{2}{*}{33} & MB05OJS074 & $\begin{array}{l}\text { RED RIVER AT } \\
\text { SELKIRK BRIDGE }\end{array}$ & Two period & $1985-2000$ & Yes & 0.0099 & Significant & 116 & 142 & 22 \\
\hline & & & & $2000-15$ & -- & 0.0000 & Significant & 142 & 220 & 55 \\
\hline \multicolumn{11}{|c|}{ Total dissolved solids, in milligrams per liter } \\
\hline \multirow[t]{3}{*}{11} & USGS-05059000 & $\begin{array}{l}\text { SHEYENNE RIVER } \\
\text { NEAR KINDRED }\end{array}$ & Three period & $1970-85$ & No & 0.0268 & Mildly significant & 565 & 495 & -13 \\
\hline & & & & $1985-2000$ & -- & 0.0000 & Significant & 495 & 656 & 33 \\
\hline & & & & $2000-15$ & -- & 0.0000 & Significant & 655 & 807 & 23 \\
\hline \multirow[t]{2}{*}{15} & USGS-05064500 & $\begin{array}{l}\text { RED RIVER OF THE } \\
\text { NORTH AT } \\
\text { HALSTAD, ND }\end{array}$ & Two period & $1985-2000$ & No & 0.0944 & Nonsignificant & 420 & 464 & 10 \\
\hline & & & & $2000-15$ & -- & 0.0024 & Significant & 464 & 593 & 28 \\
\hline \multirow[t]{2}{*}{26} & MA05OC0001 & $\begin{array}{l}\text { RED RIVER AT } \\
\text { EMERSON, MB }\end{array}$ & Two period & 1985-2000 & No & 0.0004 & Significant & 377 & 480 & 27 \\
\hline & & & & $2000-15$ & -- & 0.0001 & Significant & 480 & 613 & 28 \\
\hline
\end{tabular}


Table 4. Summary of trend results evaluated for the historical period 1970-2015 based on data collected during 1970-2017 for sulfate, total dissolved solids, nitrate plus nitrite, and total phosphorus at selected sites in the Red River of the North Basin.-Continued

[p-value, probability; FAGMC, flow-averaged geometric mean concentration; USGS, U.S. Geological Survey; --, not applied; ND, North Dakota; MB, Manitoba; MN, Minnesota]

\begin{tabular}{|c|c|c|c|c|c|c|c|c|c|c|}
\hline $\begin{array}{l}\text { Site location } \\
\text { (fig. 1) }\end{array}$ & $\begin{array}{c}\text { Site } \\
\text { identifier }\end{array}$ & $\begin{array}{c}\text { Site } \\
\text { name }\end{array}$ & Trend model & $\begin{array}{l}\text { Trend } \\
\text { period }\end{array}$ & $\begin{array}{c}\text { Step } \\
\text { trend } \\
\text { applied }\end{array}$ & $p$-value & $\begin{array}{l}\text { Significance } \\
\text { level }\end{array}$ & 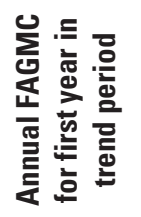 & 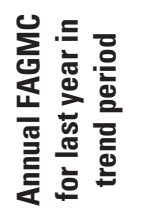 & 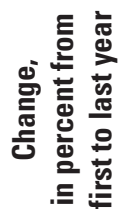 \\
\hline \multicolumn{11}{|c|}{ Total dissolved solids, in milligrams per liter-Continued } \\
\hline \multirow[t]{2}{*}{33} & MB05OJS074 & $\begin{array}{l}\text { RED RIVER AT } \\
\text { SELKIRK BRIDGE }\end{array}$ & Two period & $1985-2000$ & Yes & 0.0877 & Nonsignificant & 481 & 508 & 5 \\
\hline & & & & $2000-15$ & -- & 0.0000 & Significant & 508 & 658 & 30 \\
\hline \multicolumn{11}{|c|}{ Nitrate plus nitrite, in milligrams per liter } \\
\hline \multirow[t]{2}{*}{11} & USGS-05059000 & $\begin{array}{c}\text { SHEYENNE RIVER } \\
\text { NEAR KINDRED }\end{array}$ & Two period & $1985-2000$ & No & 0.7200 & Nonsignificant & 0.18 & 0.17 & -6 \\
\hline & & & & $2000-15$ & -- & 0.0065 & Significant & 0.17 & 0.09 & -47 \\
\hline \multirow[t]{2}{*}{15} & USGS-05064500 & $\begin{array}{l}\text { RED RIVER OF THE } \\
\text { NORTH AT } \\
\text { HALSTAD, ND }\end{array}$ & Two period & $1985-2000$ & No & 0.0001 & Significant & 0.32 & 0.59 & 85 \\
\hline & & & & $2000-15$ & -- & 0.0297 & Mildly significant & 0.59 & 0.80 & 36 \\
\hline \multirow[t]{2}{*}{26} & MA05OC0001 & $\begin{array}{l}\text { RED RIVER AT } \\
\text { EMERSON, MB }\end{array}$ & Two period & $1985-2000$ & No & 0.0013 & Significant & 0.24 & 0.39 & 62 \\
\hline & & & & $2000-15$ & -- & 0.0285 & Mildly significant & 0.39 & 0.52 & 33 \\
\hline \multirow[t]{3}{*}{33} & MB05OJS074 & $\begin{array}{l}\text { RED RIVER AT } \\
\text { SELKIRK BRIDGE }\end{array}$ & Three period & $1970-85$ & No & 0.8762 & Nonsignificant & 0.33 & 0.33 & -2 \\
\hline & & & & 1985-2000 & -- & 0.0001 & Significant & 0.33 & 0.61 & 86 \\
\hline & & & & $2000-15$ & -- & 0.5091 & Nonsignificant & 0.61 & 0.65 & 7 \\
\hline \multicolumn{11}{|c|}{ Total phosphorus, in milligrams per liter } \\
\hline \multirow[t]{3}{*}{11} & USGS-05059000 & $\begin{array}{l}\text { SHEYENNE RIVER } \\
\text { NEAR KINDRED }\end{array}$ & Three period & $1970-85$ & No & 0.3615 & Nonsignificant & 0.23 & 0.18 & -19 \\
\hline & & & & $1985-2000$ & -- & 0.1658 & Nonsignificant & 0.18 & 0.16 & -14 \\
\hline & & & & $2000-15$ & -- & 0.9943 & Nonsignificant & 0.16 & 0.16 & -0.1 \\
\hline \multirow[t]{3}{*}{15} & USGS-05064500 & $\begin{array}{l}\text { RED RIVER OF THE } \\
\text { NORTH AT } \\
\text { HALSTAD, ND }\end{array}$ & Three period & $1970-85$ & No & 0.0030 & Significant & 0.45 & 0.34 & -25 \\
\hline & & & & $1985-2000$ & -- & 0.0047 & Significant & 0.34 & 0.43 & 29 \\
\hline & & & & $2000-15$ & -- & 0.0363 & Mildly significant & 0.43 & 0.35 & -20 \\
\hline
\end{tabular}


Table 4. Summary of trend results evaluated for the historical period 1970-2015 based on data collected during 1970-2017 for sulfate, total dissolved solids, nitrate plus nitrite, and total phosphorus at selected sites in the Red River of the North Basin.-Continued

[ $p$-value, probability; FAGMC, flow-averaged geometric mean concentration; USGS, U.S. Geological Survey; --, not applied; ND, North Dakota; MB, Manitoba; MN, Minnesota]

\begin{tabular}{|c|c|c|c|c|c|c|c|c|c|c|}
\hline $\begin{array}{l}\text { Site location } \\
\text { (fig. 1) }\end{array}$ & $\begin{array}{c}\text { Site } \\
\text { identifier }\end{array}$ & $\begin{array}{c}\text { Site } \\
\text { name }\end{array}$ & Trend model & $\begin{array}{l}\text { Trend } \\
\text { period }\end{array}$ & $\begin{array}{c}\text { Step } \\
\text { trend } \\
\text { applied }\end{array}$ & $p$-value & $\begin{array}{c}\text { Significance } \\
\text { level }\end{array}$ & 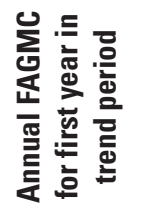 & 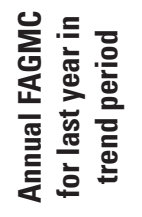 & 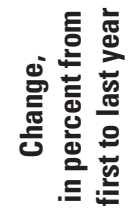 \\
\hline \multicolumn{11}{|c|}{ Total phosphorus, in milligrams per liter-Continued } \\
\hline \multirow[t]{3}{*}{19} & USGS-05079000 & $\begin{array}{l}\text { RED LAKE RIVER AT } \\
\text { CROOKSTON, MN }\end{array}$ & Three period & $1970-85$ & No & 0.3638 & Nonsignificant & 0.08 & 0.07 & -18 \\
\hline & & & & $1985-2000$ & -- & 0.1655 & Nonsignificant & 0.07 & 0.06 & -16 \\
\hline & & & & $2000-15$ & -- & 0.2923 & Nonsignificant & 0.06 & 0.06 & 13 \\
\hline \multirow[t]{2}{*}{26} & MA05OC0001 & $\begin{array}{l}\text { RED RIVER AT } \\
\text { EMERSON, MB }\end{array}$ & Two period & $1985-2000$ & No & 0.0002 & Significant & 0.18 & 0.24 & 36 \\
\hline & & & & $2000-15$ & -- & 0.0062 & Significant & 0.24 & 0.29 & 20 \\
\hline \multirow[t]{3}{*}{33} & MB05OJS074 & $\begin{array}{l}\text { RED RIVER AT } \\
\text { SELKIRK BRIDGE }\end{array}$ & Three period & $1970-85$ & Yes & 0.3210 & Nonsignificant & 0.23 & 0.18 & -9 \\
\hline & & & & $1985-2000$ & -- & 0.0092 & Significant & 0.18 & 0.16 & 29 \\
\hline & & & & $2000-15$ & -- & 0.1714 & Nonsignificant & 0.16 & 0.16 & 10 \\
\hline
\end{tabular}




\section{Sulfate and Total Dissolved Solids}

For the historical period, sulfate and total dissolved solids concentrations have steadily increased since the mid-1980s for all four sites analyzed (table 4, figs. 16 and 17). During the early period (1970-85), there was a relatively small and mildly significant decrease for both constituents for site 11 (the only site that could be analyzed for the early period). However, sulfate and total dissolved solids concentrations for all sites increased significantly during the middle (1985-2000) and recent (2000-15) periods except for nonsignificant increases during the middle period for total dissolved solids for sites 15 and 33. During the middle period, for sites 11 and 26, there were large (greater than 50 percent) and significant increases in sulfate concentration and moderate (between 25 and 50 percent) and significant increases in total dissolved solids concentration (table 4, figs. 16 and 17). Although increases for the other sites were smaller and less significant, sites 15 and 33 had sparser sampling frequencies during the middle period compared to sites 11 and 26, and therefore, the trends for sites 15 and 33 are more uncertain. During the recent period, there were moderate to large and significant increases in sulfate and total dissolved solids for all four sites. Combining the middle and recent periods, from 1985 through 2015, there were large increases in the FAGMCs of sulfate and total dissolved solids for all four sites. The FAGMC of sulfate more than doubled for site 11 (from $138 \mathrm{mg} / \mathrm{L}$ in 1985 to $312 \mathrm{mg} / \mathrm{L}$ in 2015), site 15 (from 101 to $227 \mathrm{mg} / \mathrm{L}$ ), and site 26 (from 73.0 to $187 \mathrm{mg} / \mathrm{L}$ ) and nearly doubled for site 33 (from 116 to $220 \mathrm{mg} / \mathrm{L}$ ). During the same time, the FAGMC of total dissolved solids increased by nearly 50 percent or more for all four sites. From 1985 to 2015, the FAGMC of total dissolved solids increased by about $300 \mathrm{mg} / \mathrm{L}$ or about 60 percent for site 11 (from 495 to $807 \mathrm{mg} / \mathrm{L}$, table 4) and increased by about $250 \mathrm{mg} / \mathrm{L}$ or 40 percent for site 26 (from 377 to $613 \mathrm{mg} / \mathrm{L}$, table 4). Using the WQO of $250 \mathrm{mg} / \mathrm{L}$ set for sulfate at the binational site as a reference, by 2015 , for all sites other than site 11 , the FAGMC was just slightly less than $250 \mathrm{mg} / \mathrm{L}$, but concentrations were rapidly approaching $250 \mathrm{mg} / \mathrm{L}$ (fig. 16). A similar comparison for total dissolved solids indicates by 2015 for all sites, the FAGMC was greater than the total dissolved solids WQO of $500 \mathrm{mg} / \mathrm{L}$ for the binational site (fig. 17). The historical trends in sulfate and total dissolved solids indicate that the basinwide pattern of generally increasing concentrations seen in the recent period probably started earlier, around the mid-1980s, and is not indicating any signs of diminishing. In fact, concentrations for the three main-stem sites increased the same or more during $2000-15$ than during 1985-2000. As discussed previously for the recent trend period, the similar pattern and timing of the increasing sulfate and total dissolved solids concentrations and large magnitudes of the increases may indicate that the increases are related to natural hydroclimatic processes, such as rising groundwater tables or increasing contributing drainage areas, associated with the onset of wetter conditions in the 1980s.

\section{Nitrate Plus Nitrite and Total Phosphorus}

For the historical period, nitrate-plus-nitrite concentrations increased during 1985 to 2015 for the main-stem sites (sites 15, 26, and 33), but decreased for the North Dakota tributary site 11 . The only site with enough data for trend analysis during 1970-85, main-stem site 33, had virtually constant concentrations as indicated by a small nonsignificant decrease in nitrate-plus-nitrite concentration (table 4, fig. 18). During 1985 to 2015, concentrations decreased for North Dakota tributary site 11 , with a small and nonsignificant decrease ( -6 percent) during $1985-2000$ and a significant large decrease $(-47$ percent) during 2000-15 (fig. 18, table 4). In contrast, concentrations for the main-stem sites (sites 15, 26, and 33) increased during 1985 to 2015; large significant increases were observed for all three sites during 1985-2000, and during 2000-15, smaller mildly significant or nonsignificant increases were observed. As discussed previously for the recent trends (for example, see fig. 9A), the large increase in the FAGMC for site 15 during the recent period may reflect a combination of increases in concentration from tributaries in the upper Red River subbasin (possibly caused by increased subsurface drainage) and increases in urban or industrial sources of nitrate in local runoff from the Fargo, N. Dak., area, and the decrease for site 11 may reflect changes in fertilizer application rates in the basin. The similar pattern in the trends for the middle period (1985-2000) indicates that these same factors may have caused the trends during the middle period as well. Combining the middle and recent periods, overall from 1985 to 2015, the FAGMC of nitrate plus nitrite for site 15 increased from 0.32 to $0.80 \mathrm{mg} / \mathrm{L}$ or about 250 percent (table 4 ). The large increase over this period for site 15 was attenuated for site 26 but remained relatively large. From 1985 to 2015, the FAGMC for nitrate plus nitrite for site 26 increased from 0.24 to $0.52 \mathrm{mg} / \mathrm{L}$ or about 100 percent. Similarly, the FAGMC for site 33 increased from 0.33 to $0.65 \mathrm{mg} / \mathrm{L}$ or about 100 percent. The large increases in nitrate-plus-nitrite concentration in the mainstem sites since 1985 may reflect increases in nitrogen sources from urban runoff, urban or industrial point sources, or agricultural activities along the main-stem Red River. However, the smaller, less significant increases during 2000-15 indicate improvements in wastewater treatment and implementation of agricultural best management practices may be reducing nitrate-plus-nitrite loss.

The historical trend analysis of total phosphorus reveals some interesting contrasts among the two large tributary sites (sites 11 and 19), the upstream main-stem site (site 15), and the two downstream main-stem sites (sites 26 and 33). The large tributary sites, which are less affected by row crops and urban development compared to main-stem sites, generally had lower total phosphorus concentrations compared to main-stem sites (fig. 19). Furthermore, total phosphorus concentrations for both tributary sites decreased during 1970 through 2000 and then remained virtually constant after 2000, as indicated by the small nonsignificant downward trends for both sites during the early (1970-85) and middle (1985-2000) 


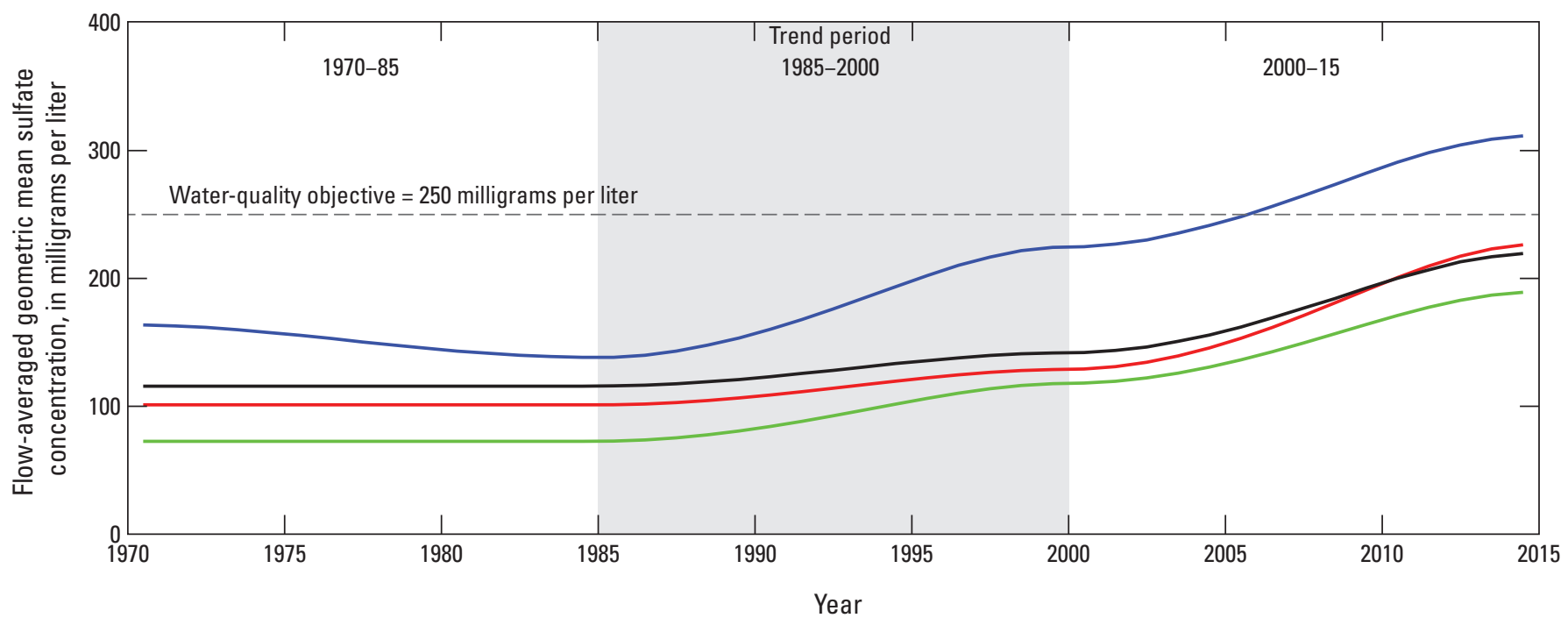

\section{EXPLANATION}

$\begin{array}{ll}\text { - Sheyenne River near Kindred, North Dakota—Site } 11 & \text { Red River at Emerson, Manitoba-Site } 26 \\ \text { — Red River of the North at Halstad, North Dakota—Site } 15 & - \text { Red River at Selkirk Bridge, Manitoba-Site } 33\end{array}$

Figure 16. Fitted trend in annual flow-averaged geometric mean concentration of sulfate evaluated for the historical period 1970-2015 at selected sites in the Red River of the North Basin.

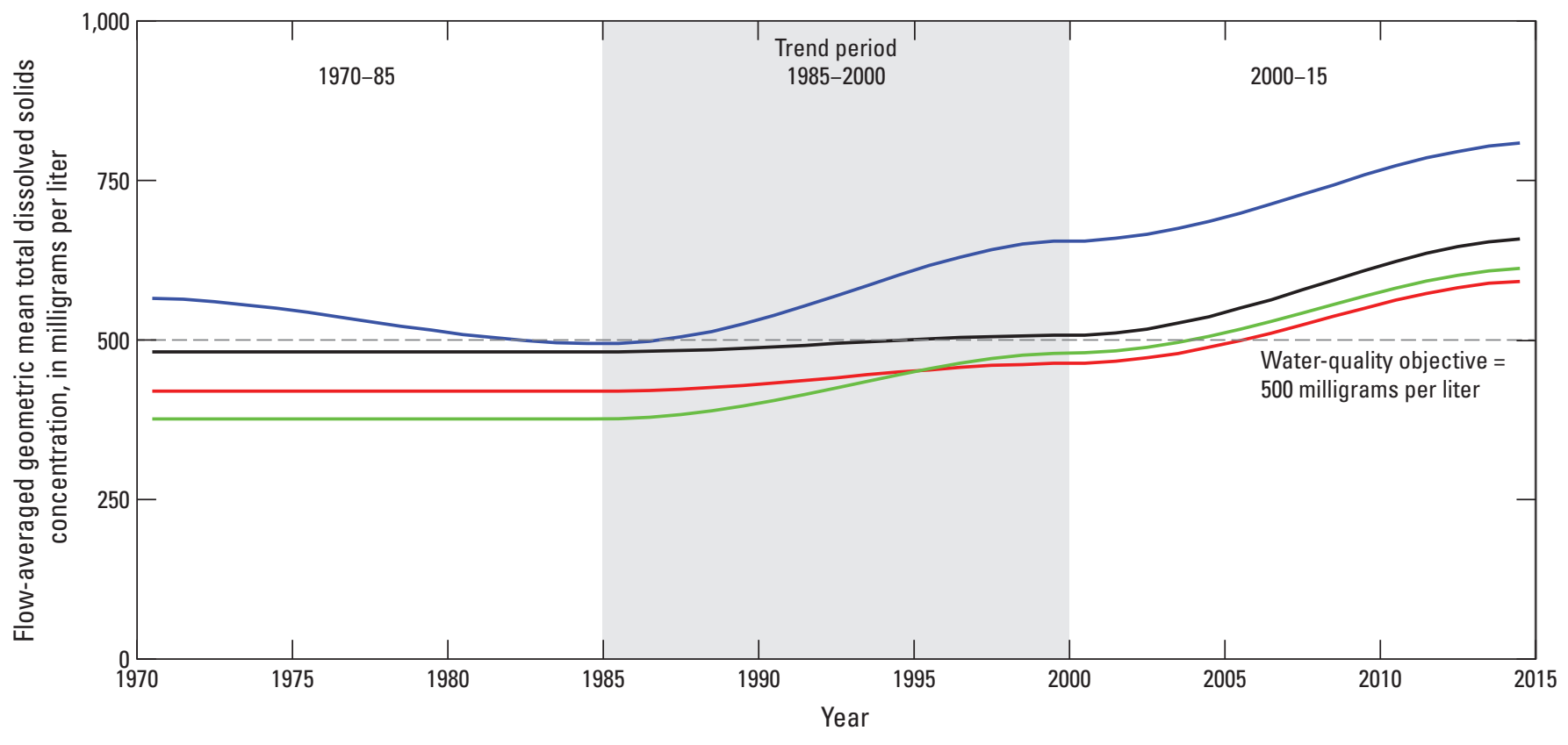

EXPLANATION

— Sheyenne River near Kindred, North Dakota-Site 11

— Red River at Emerson, Manitoba-Site 26

— Red River of the North at Halstad, North Dakota—Site 15

— Red River at Selkirk Bridge, Manitoba-Site 33

Figure 17. Fitted trend in annual flow-averaged geometric mean concentration of total dissolved solids evaluated for the historical period 1970-2015 at selected sites in the Red River of the North Basin. 


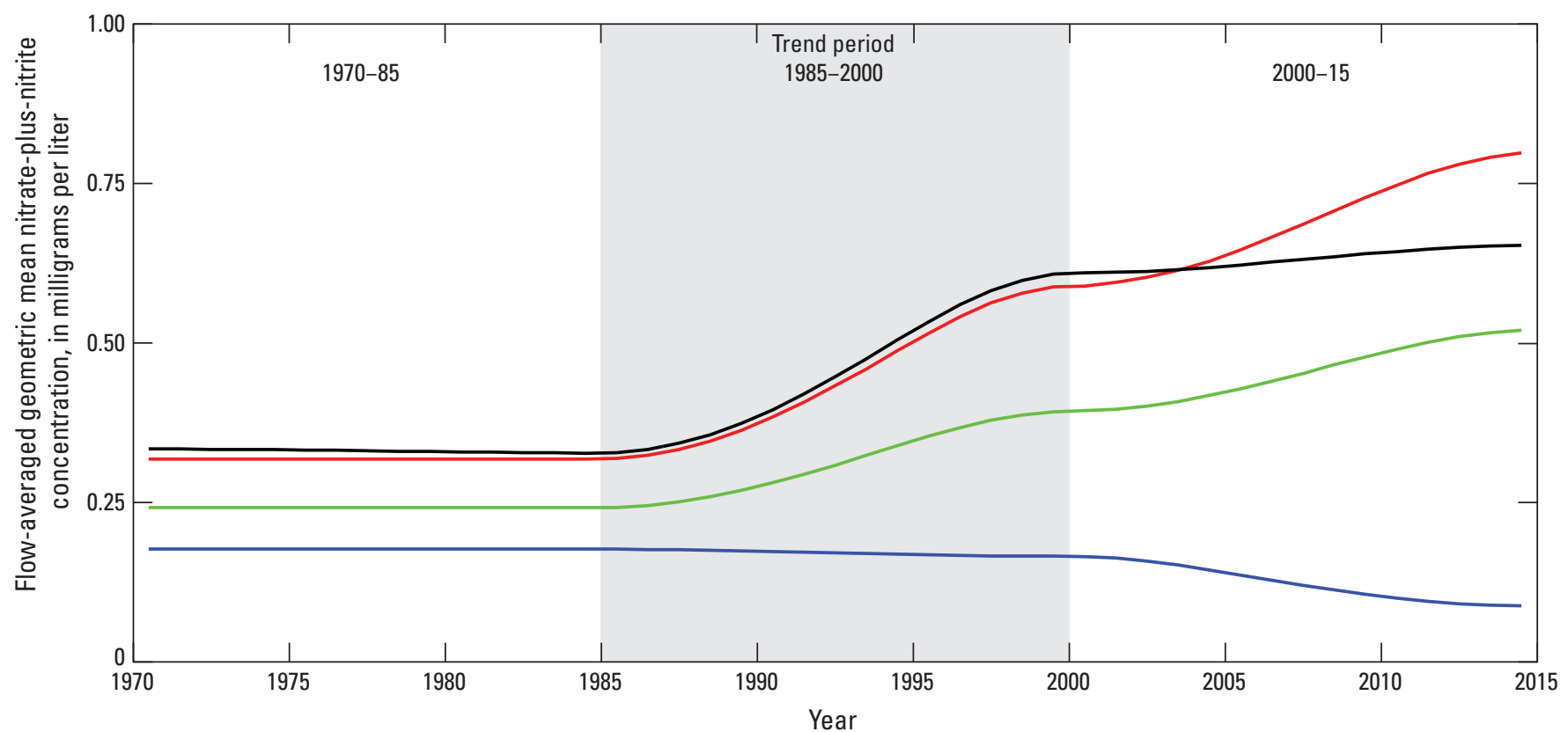

\section{EXPLANATION}
— Sheyenne River near Kindred, North Dakota—Site 11
— Red River at Emerson, Manitoba—Site 26
— Red River of the North at Halstad, North Dakota—Site 15
— Red River at Selkirk Bridge, Manitoba-Site 33

Figure 18. Fitted trend in annual flow-averaged geometric mean concentration of nitrate plus nitrite evaluated for the historical period 1970-2017 at selected sites in the Red River of the North Basin.

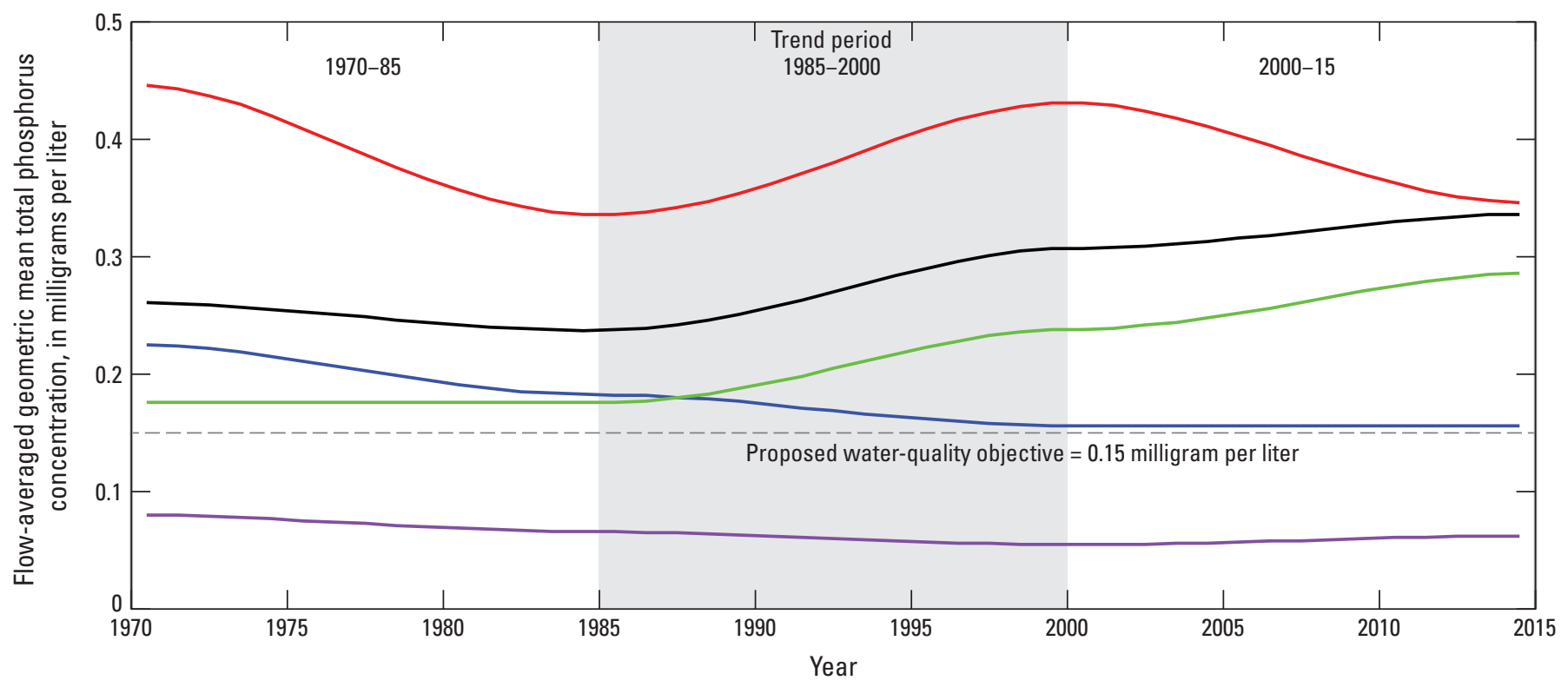

EXPLANATION

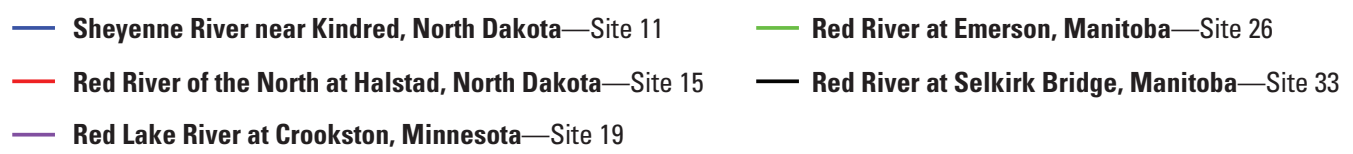

Figure 19. Fitted trend in annual flow-averaged geometric mean concentration of total phosphorus evaluated for the historical period 1970-2015 at selected sites in the Red River of the North Basin. 
periods and even smaller nonsignificant trends during the recent period (table 4). The first main-stem site (site 15), which is in the upper Red River subbasin, had a much higher concentration compared the large tributary sites, and the trend was more complex. For site 15, the FAGMC for total phosphorus decreased from 0.45 to $0.34 \mathrm{mg} / \mathrm{L}$ during $1970-85$, increased from 0.34 to $0.43 \mathrm{mg} / \mathrm{L}$ during $1985-2000$, and then decreased back down to $0.35 \mathrm{mg} / \mathrm{L}$ by 2015 . Site 15 is heavily affected by row crops and urban development in the Fargo area, which may explain some of the complexity of the trend. The two main-stem sites in the lower Red River subbasin had similar increases in total phosphorus concentrations compared to site 15 during 1985-2000; however, unlike site 15 , total phosphorus concentrations for the two downstream main-stem sites increased during 2000-15 (significantly for site 26). Using the proposed WQO of $0.15 \mathrm{mg} / \mathrm{L}$ for total phosphorus at the binational site for comparison, by 2015 , for all sites other than site 19, the FAGMC was greater than $0.15 \mathrm{mg} / \mathrm{L}$, but concentrations for site 11 were approaching $0.15 \mathrm{mg} / \mathrm{L}$ by 2015 (fig. 19). For the downstream main-stem sites (sites 26 and 33), the FAGMC was greater than $0.15 \mathrm{mg} / \mathrm{L}$ during the whole period and continued to increase, moving farther away from $0.15 \mathrm{mg} / \mathrm{L}$.

Comparing and contrasting the historical nutrient concentration trends for total phosphorus and nitrate plus nitrite and among tributary and main-stem sites for the various trend periods can provide clues to the potential causes for the nutrient trends. For example, the similar increases in total phosphorus and nitrate-plus-nitrite concentration for the main-stem sites during 1985-2000, combined with small decreases in both constituents for the large tributary sites, indicates increasing inputs of both nutrients from urban, industrial, or agricultural sources along the main-stem, but not in the tributary sites during this period. A similar pattern was detected for the downstream main-stem sites (sites 26 and 33) during 2000-15, with increasing concentrations of both nutrients; however, for site 15 , total phosphorus concentration decreased during that time, as did total phosphorus concentrations in many tributaries in the upper basin (as discussed in the "Recent WaterQuality Trends" section of this report). This pattern of phosphorus and nitrogen trends indicates a human-induced change in the upper basin during that time that reduced the sources of phosphorous, but not nitrogen, and that was widespread throughout the upper basin rather than focused along the main stem. For nutrients, unlike sulfate and total dissolved solids, main-stem sites indicated similar patterns over time but differed from tributary sites. Trends in main-stem sites reflected the combined conditions of the tributaries and localized effects along the main stem. Determining the cause of the continued increase in total phosphorus for the downstream main-stem sites requires further investigation. Trend attribution analysis or a dynamic source-and-transport basin model would be necessary to pinpoint the causes of the historical trends, which was beyond the scope of the current study.

\section{Water-Quality Conditions at the Binational Site}

Water quality for the binational site, Red River at Emerson, Manitoba (site 26), is of interest to the United States and Canada, and the site has been monitored intensively for water quality since the 1970s. Changes in water quality over time for the binational site reflect the mixing of tributary contributions with main-stem sites as well as the complex interaction of human-induced changes to the landscape. For five constituents with an established or proposed WQO for the binational site, annual GMC, fitted trend in annual FAGMC, annual load, fitted trend in annual flow-averaged load and flow-averaged exceedance probability and fitted trend in flowaveraged exceedance probability for constituent WQOs was evaluated and presented for the historical period (1970-2015).

\section{Annual Geometric Mean Concentration}

For the binational site (site 26), during the historical period (1970-2015), the annual FAGMC of dissolved ions (sulfate, chloride, and total dissolved solids) increased (fig. 20, table 5). For the dissolved ions, because enough data were available for all three constituents for the period, a threeperiod trend model (1970-85, 1985-2000, and 2000-15) was used for each constituent. In figure 20, the solid line is the same fitted trend in annual FAGMC (assumes flow conditions were uniform year after year and consisted of average conditions for the period of record, 1970-2015) that was presented in the "Historical Water-Quality Trends" section, and the red points are the estimated annual GMC for each year (not flow averaged, so including year-to-year flow-related variability). Sulfate concentration had less flow-related variability compared to the other constituents, as indicated by the small deviations of the points from the fitted trend line. The low variability for sulfate results from the GMC for a given year representing "typical" concentrations during the year, in that the concentration is greater than the GMC about half the time and less than the GMC about half the time. For basins with a large supply of sulfur in soils, the GMC generally is closely correlated with the concentration of shallow groundwater runoff, which remains relatively constant from year to year irrespective of interannual streamflow variability. Consistent with the trends previously presented for site 26 (figs. 16 and 17 , table 4), large, significant increases in sulfate and total dissolved solids concentrations occurred during the two later periods (1985-2000 and 2000-15) and indicated no sign of diminishing. Similarly, chloride indicated a large significant increase of around 30 percent for the two later periods, which is similar in magnitude to increases for total dissolved solids during the same periods. During the earliest period (1970-85), concentrations of sulfate were virtually stable, as indicated by the small and nonsignificant trend, but chloride and total dissolved solids concentrations indicated mildly significant and 


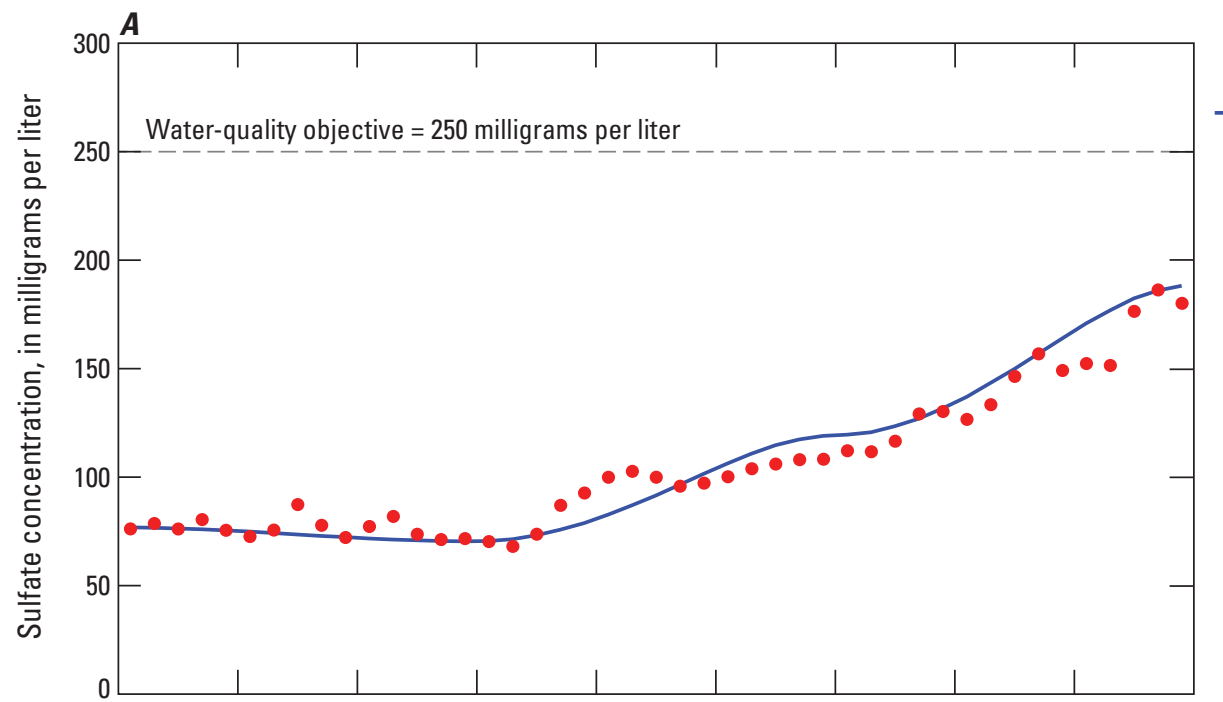

\section{EXPLANATION}

- Fitted trend in annual flow-averaged geometric mean concentration

- Annual geometric mean concentration
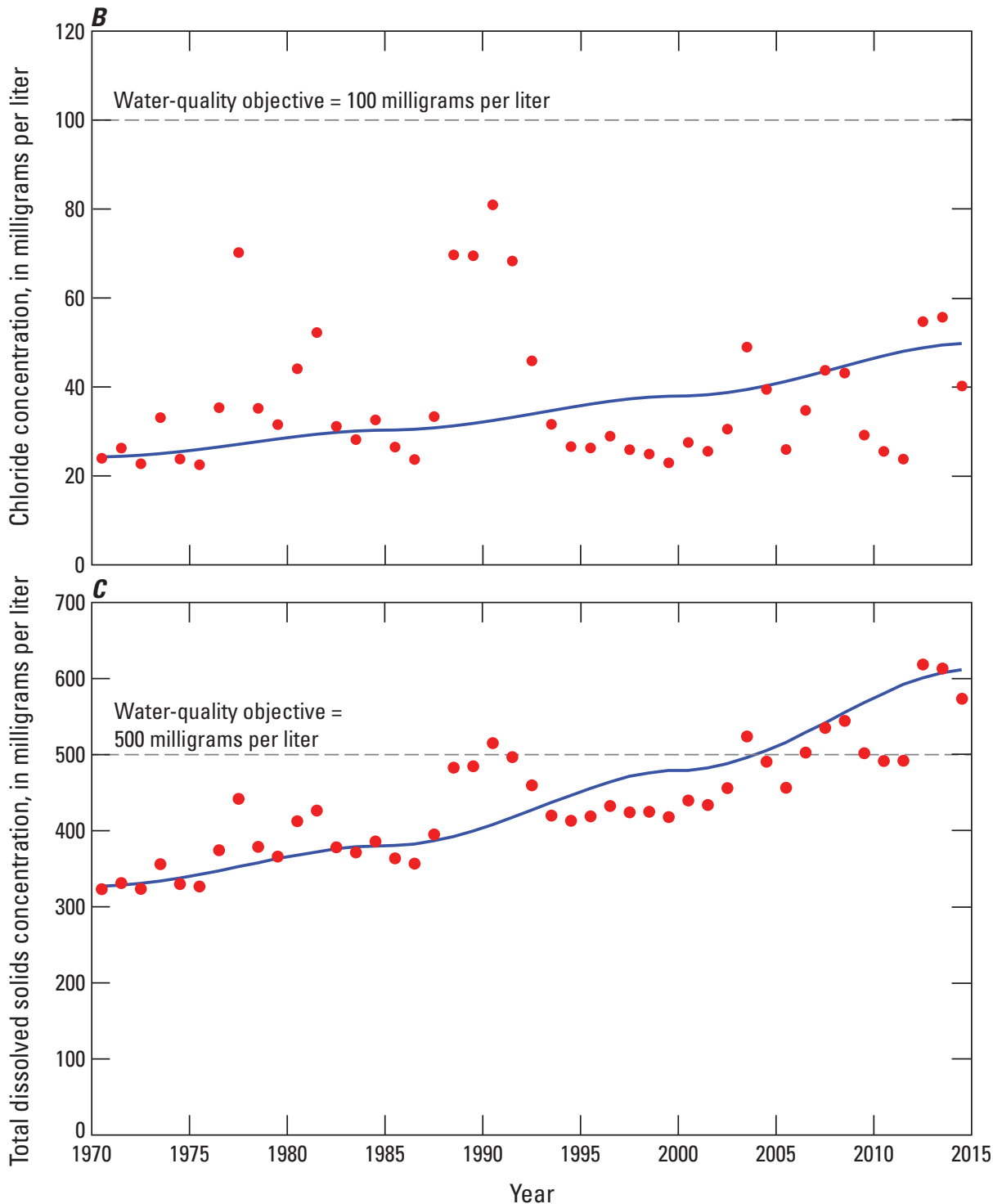

Figure 20. Annual geometric mean concentration and fitted trends in annual flow-averaged geometric mean concentration for the historical period 1970-2015 at the binational site, Red River of the North at Emerson, Manitoba. $A$, sulfate; $B$, chloride; $C$, total dissolved solids. 
Table 5. Summary of trend results and annual loads evaluated for the historical period 1970-2015 based on data collected during 1970-2017 for sulfate, chloride, total dissolved solids, total nitrogen, and total phosphorus for the binational site, Red River of the North at Emerson, Manitoba.

[ $p$-value, probability; FAGMC, flow-averaged geometric mean concentration; mg/L, milligram per liter; WQO, water-quality objective; --, no data or not applicable]

\begin{tabular}{|c|c|c|c|c|c|c|c|c|c|c|c|}
\hline Trend model & $\begin{array}{l}\text { Trend } \\
\text { period }\end{array}$ & $\begin{array}{c}\text { Step } \\
\text { trend } \\
\text { applied }\end{array}$ & $p$-value & $\begin{array}{c}\text { Significance } \\
\text { level }\end{array}$ & 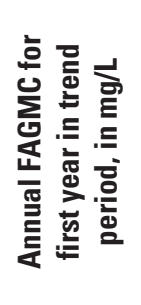 & 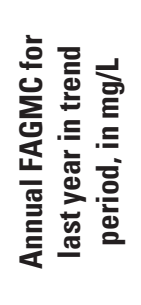 & 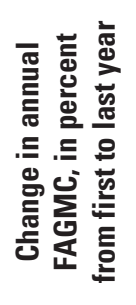 & 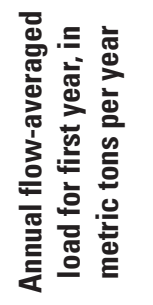 & 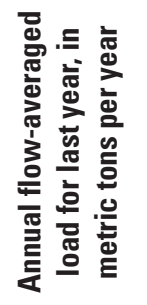 & 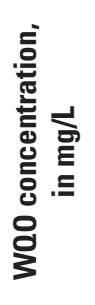 & 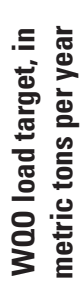 \\
\hline \multicolumn{12}{|c|}{ Sulfate } \\
\hline \multirow[t]{3}{*}{ Three period } & $1970-85$ & No & 0.3744 & Nonsignificant & 76.8 & 70.6 & -8 & 410,000 & 376,000 & 250 & -- \\
\hline & $1985-2000$ & -- & 0.0000 & Significant & 70.6 & 120 & 69 & 376,000 & 638,000 & -- & -- \\
\hline & $2000-15$ & -- & 0.0000 & Significant & 120 & 189 & 58 & 638,000 & $1,010,000$ & -- & -- \\
\hline \multicolumn{12}{|c|}{ Chloride } \\
\hline \multirow[t]{3}{*}{ Three period } & $1970-85$ & No & 0.0240 & Mildly significant & 24.3 & 30.3 & 25 & 117,000 & 145,000 & 100 & -- \\
\hline & $1985-2000$ & -- & 0.0085 & Significant & 30.3 & 38.0 & 25 & 145,000 & 182,000 & -- & -- \\
\hline & $2000-15$ & -- & 0.0006 & Significant & 38.0 & 49.8 & 31 & 182,000 & 239,000 & -- & -- \\
\hline \multicolumn{12}{|c|}{ Total dissolved solids } \\
\hline \multirow[t]{3}{*}{ Three period } & $1970-85$ & No & 0.5413 & Nonsignificant & 327 & 381 & 16 & $1,570,000$ & $1,830,000$ & 500 & -- \\
\hline & $1985-2000$ & -- & 0.0009 & Significant & 381 & 479 & 26 & $1,830,000$ & $2,300,000$ & -- & -- \\
\hline & $2000-15$ & -- & 0.0001 & Significant & 479 & 612 & 28 & $2,300,000$ & $2,940,000$ & -- & -- \\
\hline \multicolumn{12}{|c|}{ Total nitrogen } \\
\hline \multirow[t]{2}{*}{ Two period } & $1980-95$ & Yes & 0.0016 & Significant & 1.76 & 1.35 & -23 & 13,760 & 10,500 & 1.15 & 9,525 \\
\hline & $2000-15$ & -- & 0.1139 & Nonsignificant & 1.35 & 1.44 & 7 & 10,500 & 11,200 & -- & -- \\
\hline \multicolumn{12}{|c|}{ Total phosphorus } \\
\hline \multirow[t]{2}{*}{ Two period } & $1980-95$ & -- & 0.0001 & Significant & 0.17 & 0.23 & 35 & 1,460 & 1,960 & 0.15 & 1,400 \\
\hline & $2000-15$ & -- & 0.0006 & Significant & 0.23 & 0.29 & 26 & 1,960 & 2,480 & -- & -- \\
\hline
\end{tabular}


nonsignificant increases (fig. 20, table 5). During the two earlier periods, the FAGMCs for all constituents were much less than the WQO, but during 2000-15, the increasing FAGMC for sulfate approached the WQO, and in the early 2000 s, total dissolved solids concentrations began surpassing the WQO.

Generally, total nitrogen concentrations decreased and total phosphorus concentrations increased for the binational site (site 26) during the historical period (fig. 21, table 5). To compare total nitrogen and total phosphorus, the same two-period trend model consisting of two monotonic trends, 1980-95 and 2000-15, was used (table 5). This model differs from the historical trend model for total phosphorus for site 26 discussed previously (table 4) because of modifications that were required for total nitrogen; namely, the two monotonic trends from the previous model for the early and middle periods were replace by a single trend spanning the two periods
(1980-95). This change was based on three considerations: (1) data from 1970 to 1980 were absent for total nitrogen; (2) a significant step trend was detected and applied for total nitrogen because of a laboratory-analytical method change on October 1, 1993, which was close to the midpoint of the middle period (1985-2000), and thus, the step trend was confounded with the monotonic trend during the middle period; and (3) the best fit trend model had a gap in the trend periods between 1995 and 2000. Between the period gap, the trend is assumed to remain constant. For the modified two-period trend model, during 1980-95, total nitrogen significantly decreased by 23 percent, and during 2000-15, concentrations were virtually stable, as indicated by a nonsignificant increase of 7 percent (table 5, fig. 21A). The annual FAGMC decreased from $1.76 \mathrm{mg} / \mathrm{L}$ in 1980 to $1.35 \mathrm{mg} / \mathrm{L}$ in 1995 and increased to $1.44 \mathrm{mg} / \mathrm{L}$ in 2015 (fig. 21, table 5). In contrast,

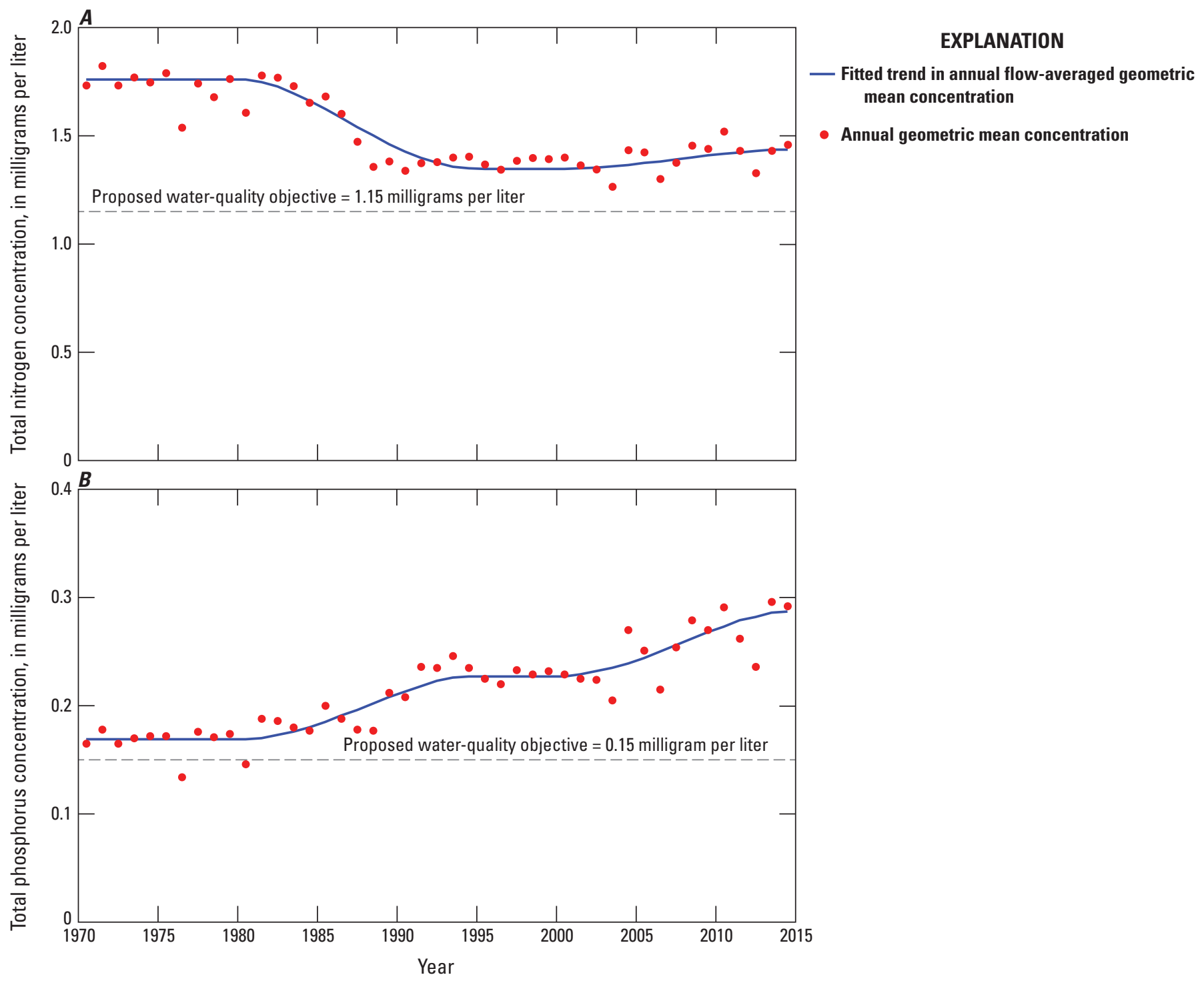

Figure 21. Annual geometric mean concentration and fitted trends in annual flow-averaged geometric mean concentration for the historical period 1970-2015 at the binational site, Red River of the North at Emerson, Manitoba. $A$, total nitrogen; B, total phosphorus. 
the annual FAGMC of total phosphorus significantly increased by more than 25 percent during both periods, increasing from $0.17 \mathrm{mg} / \mathrm{L}$ in 1980 to $0.23 \mathrm{mg} / \mathrm{L}$ in 1995 and to $0.29 \mathrm{mg} / \mathrm{L}$ in 2015 (table 5). For total nitrogen, although the annual FAGMC was much greater than the proposed WQO during 1980, concentrations moved toward the WQO during 1980-95 and then remained virtually stable but greater than the WQO through 2015. For total phosphorus, the FAGMC was slightly greater than the WQO through 1980 and moved increasingly farther away during 1980-2015.

\section{Annual Load}

Monitoring results of load reduction based on annual loads from year to year can be misleading because large reductions or increases happen from one year to the next, depending largely on streamflow. In a basin with highly variable streamflow, the trend in flow-averaged load is a more robust measure of progress. Similar to the trend in annual FAGMC, the trend in load is referred to as a flow-averaged trend because it is the trend that would have occurred under the hypothetical assumption that flow conditions were the same year after year during the historical period (Vecchia and Nustad, 2020). In other trend-analysis approaches, this is sometimes referred to as a trend in "flow-normalized" loads. In figures 22 and 23, trends in annual flow-averaged load along with the estimated annual loads (including interannual flow-related variability) for five constituents (sulfate, chloride, total dissolved solids, total nitrogen, and total phosphorus) are shown. The annual loads are not flow averaged and as such represent the estimated amount of a constituent transported by the Red River flowing across the international boundary each year. Similar to the FAGMC, the trend in annual flow-averaged load indicates much less interannual variability because variability caused by year-to-year changes in streamflow has been removed. In contrast, the annual loads, the points scattered about the flowaveraged trend line, demonstrate the year-to-year variability of loads because of variability in streamflow. Compared to annual GMC, annual loads have much more interannual variability because the flow-related variability in concentration is magnified by variability in annual flow volume. Depending on the constituent, periods of high or low concentrations in relation to streamflow are primarily driven by the primary source and transport mechanism. For dissolved ions (sulfate, chloride, and total dissolved solids), concentrations are highest during lower streamflow years because of groundwater contributions and lowest during higher streamflow years because of dilution from surface runoff. Although the annual loads are larger during wet years and smaller during dry years, the interannual variability is reduced because the lower concentrations offset the higher flow volumes during wet years. In contrast, for constituents such as total phosphorus and total nitrogen, which have higher concentrations with higher flows because of surface runoff, concentrations and flow volumes are largest during wet years. An example of this can be seen by comparing concentrations and loads of chloride and total phosphorus during a dry and wet period: 1988-92, a period when the basin experienced a severe drought and streamflow was much less than normal, and 2009-11, a period of major spring flooding when streamflow was much greater than normal (Vecchia, 2003). During 1988-92, some of highest annual GMCs occurred (fig. 20B), but annual chloride loads were some of the smallest (fig. 22B). For total phosphorus, concentrations were low (fig. $21 B$ ), and because streamflow was less than normal, loads for total phosphorus were small (fig. 23B). In contrast, during 2009-11, chloride concentrations were some of the lowest, but loads were the largest of the period; however, although loads were large, they were only about 25 percent larger than the flow-averaged load for those years. For the wetter period, total phosphorus concentrations were high, and loads were much larger than normal. Annual loads for those years were about 200 percent larger than the flow-averaged load; hence, the trend in annual flow-averaged load is a robust measure of change over time that is not driven by extreme interannual variability in streamflow conditions.

Large increases in annual flow-averaged loads occurred for dissolved ions at the binational site (site 26, table 5 and fig. 22). The annual flow-averaged sulfate load nearly tripled between 1985 and 2015 from 376,000 to more than 1 million metric tons per year. The annual flow-averaged chloride and total dissolved solids loads increased about 1.5 times between 1985 and 2015 from 145,000 to 239,000 metric tons per year and from about 1.8 million to about 2.9 million metric tons per year, respectively (table 5).

Annual flow-averaged loads decreased for total nitrogen and increased for total phosphorus since 1980 (fig. 23, table 5). Although the load target WQOs proposed by the IRRB use a 5-year running average load to determine exceedances for total phosphorus and total nitrogen, the load target WQOs were used for reference against which to compare annual loads and annual flow-averaged loads (fig. 23). In comparison to the load target WQO for total nitrogen, annual loads for most years during lower streamflow years (before 1995 ) were less than 9,525 metric tons per year, but later, during the higher streamflow years (2000-15), most years were greater than 9,525 metric tons per year (fig. 23A). In contrast, the flow-averaged nitrogen load decreased during the lower streamflow years, dropping from about 13,800 metric tons per year in 1980 to 10,500 metric tons per year in 1995 and was virtually stable (as indicated by the small nonsignificant trend) during the higher streamflow period (fig. $23 \mathrm{~A}$ and table 5). Since 1980, the flow-averaged nitrogen load has decreased, moving closer to the load target WQO for total nitrogen of 9,525 metric tons per year (table 5 and fig. 23A). Like total nitrogen, during lower streamflow years (before 1995), annual loads for total phosphorus were less than the load target WQO, but during higher streamflow years, annual loads were nearly all greater than 1,400 metric tons per year (fig. 23B). Unlike total nitrogen, the annual flow-averaged total phosphorus load increased during the drier period and the wetter period, nearly doubling from 1,460 metric tons per year in 1980 to 

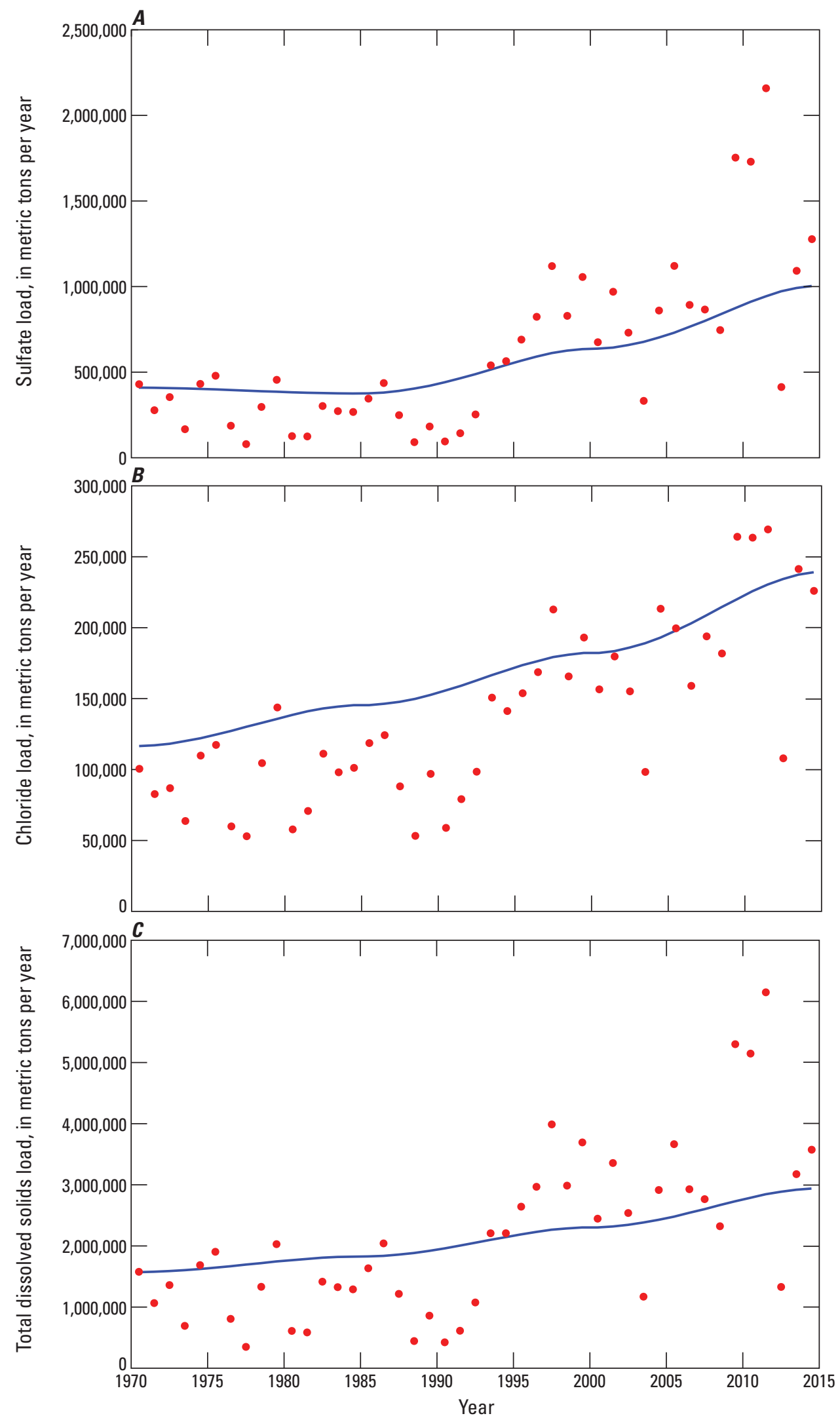

Figure 22. Annual load and fitted trend in annual flow-averaged load for the historical period 1970-2015 at the binational site, Red River of the North at Emerson, Manitoba. $A$, sulfate; $B$, chloride; $C$, total dissolved solids. 


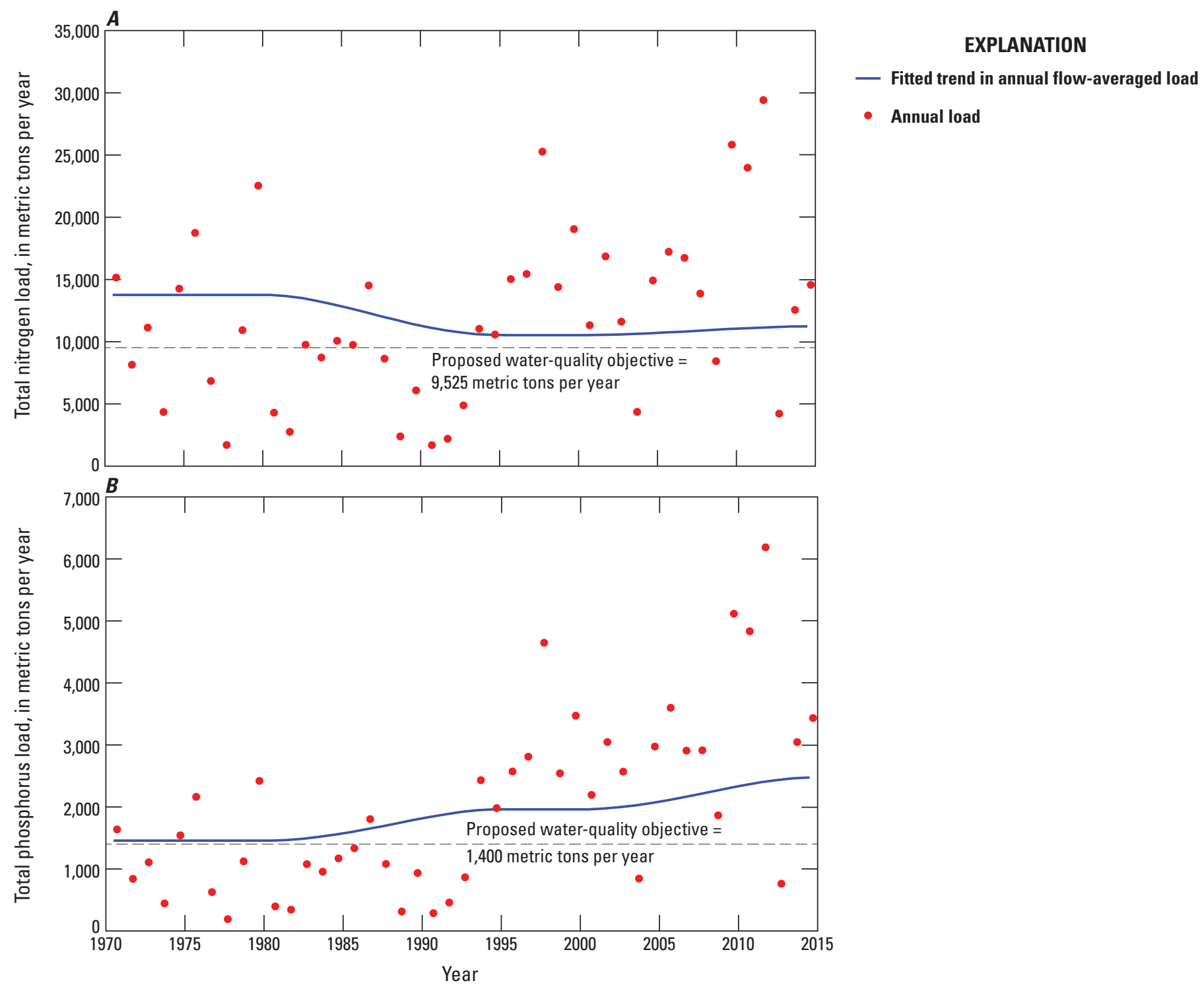

Figure 23. Annual load and fitted trend in annual flow-averaged load for the historical period 1970-2015 at the binational site, Red River of the North at Emerson, Manitoba. $A$, total nitrogen; $B$, total phosphorus.

2,480 metric tons per year in 2015 (table 5 and fig. 23B). Also different from total nitrogen, the annual flow-averaged total phosphorus load was near the proposed WQO load target of 1,400 metric tons per year at the beginning of the period but steadily increased, moving away from the load target by the end of the trend period (2015).

\section{Flow-Averaged Exceedance Probability}

Two measures of exceedance probabilities, flow-averaged exceedance probability (FAEP) and annual mean FAEP, are produced from R-QWTREND to describe the probability of exceeding a specified concentration threshold (Vecchia and Nustad, 2020). Like the annual FAGMC and annual flowaveraged loads previously presented, the flow averaging removes year-to-year variability in the exceedance probability because of changing streamflow conditions. For the current study, the specified concentration threshold is defined as the WQO for a given constituent. The annual mean FAEP is a measure of the proportion of time during the year concentrations are expected to exceed the WQO, assuming average flow conditions. For example, if the annual mean FAEP for a specified year equals 0.25 (or one-fourth of the year), it is expected that the WQO would be exceeded about 25 percent of the time (about 90 days) during that year assuming normal flow conditions. The trend in annual mean FAEP for the various constituents is the change in FAEP over the trend period resulting from the concentration trends described previously. In addition to the proportion of time during the year concentrations are expected to exceed the WQO, it is important to consider the 
time of year in which concentrations are most likely to exceed the WQO. The FAEP is computed by R-QWTREND for each 5 -day time interval in the period of record and is interpreted as the chance of exceeding the WQO during that time interval, assuming flow conditions were the same year after year. For example, if the FAEP equaled 0.5 for June $1-5$ of a specified year, there was an equal (50 percent) chance of exceeding the WQO during that time interval assuming "normal" (average) flow conditions for that time of year. Depending on the seasonal fluctuations in the FAEP within the year, a higher frequency of exceedances would be expected during times of year when the FAEP is high and fewer exceedances (or none if the FAEP is small) when the FAEP is low. The annual mean FAEP and FAEP during 1970-2015 are presented for sulfate, chloride, total dissolved solids, total nitrogen, and total phosphorus. To compare how the seasonal pattern in exceedances has changed through time, the FAEPs for three of the years $(1985,2000$, and 2015) that represent the start or end of a trend period for most constituents (table 5) are presented.

For sulfate, the trend in annual mean FAEP increased from 0 in 1970 to nearly 25 percent in 2015 (fig. 24A); thus, by 2015 , for average flow conditions, concentrations were expected to be greater than the WQO for sulfate 25 percent of the year or about 90 days per year compared with 0 days in 1970. A closer look at the FAEP for 1985, 2000, and 2015 (fig. 24B), indicates that in 2000, when the annual FAEP was small (about 0.02 or $1 / 50$ of the year), only a few days (about 7) were exceeding the WQO, but by 2015 , about 90 days were exceeding the WQO. Also, exceedances were most likely to occur either during late spring into early summer (May-June) and fall into early winter (October-December), when sulfate concentrations tend to be highest because of overland or shallow groundwater runoff from nonfrozen soils. By 2015, during mid-May to mid-June, concentrations during these periods had about an equal chance (50 percent) of exceeding the WQO (fig. 24B). The peak rapidly became much more pronounced by 2015, when the annual FAGMC started to approach the WQO (figs. $20 A$ and 24B). In general, the annual mean FAEP approaches 0.5 as the FAGMC approaches the WQO and increases rapidly as the FAGMC exceeds the WQO. As described previously for sulfate concentration trends, the increase in FAEP may be due in part to the onset of prolonged wet conditions in the basin starting in the mid-1990s and the cumulative effects on major-ion concentrations. The wet climatic conditions that have persisted for many years may have caused substantial changes in the hydrology and geochemistry of drainage basins and, in turn, increased the amount of sulfate in soils near the surface and (or) increased the mobility of sulfate in shallow groundwater inflow to streams.

For chloride, the trend in annual mean FAEP increased from 0 to about 7 percent between 1970 and 2015, meaning that, in 2015, concentrations were greater than the WQO of $100 \mathrm{mg} / \mathrm{L}$ about 25 days of the year (fig. 25A). The exceedances are most likely to occur during the months of October through March and are unlikely to occur from April through August (fig. 25B). During the winter months of November through January, when groundwater contributions tend to be the largest, concentrations are likely to be greater than the WQO nearly 25 percent of the time.

Like sulfate and chloride, the probability of exceeding the WQO of $500 \mathrm{mg} / \mathrm{L}$ for total dissolved solids has increased since 1970 (fig. 26A). In 1970, total dissolved solids concentrations exceeded $500 \mathrm{mg} / \mathrm{L}$ about 25 days of the year or 7 percent of the year, and in 2015, the likelihood increased to 292 days of the year or 80 percent of the year (fig. 26A). The annual FAGMC for total dissolved solids (fig. 20C) started to exceed the WQO in the early 2000s, causing a rapid increase in the annual mean FAEP (fig. 26A) after that time. Because total dissolved solids are composed of sulfate, chloride, and other major ions, the seasonal pattern reflects a blend of the seasonal patterns for the individual constituents. For total dissolved solids, the lowest probability of exceedance occurs in late March into April because of spring runoff; and probabilities rapidly increase and peak in May through mid-June, which is likely related to sulfate. Probabilities are lower during July through September, and the highest probabilities occur during the winter months of November through January because of groundwater (figs. 26B). By 2015, the seasonal pattern was much more pronounced with fewer days of concentrations less than the WQO during each season (fig. 26B).

For total nitrogen, the trend in annual mean FAEP has decreased from about 90 percent (329 days) in 1980 to about 75 percent (274 days) in 2015, meaning that concentrations are likely to be greater than $1.15 \mathrm{mg} / \mathrm{L}$ for 55 fewer days in 2015 than they were in 1980 (fig. 27A). Total nitrogen indicated a seasonal pattern with the lowest probabilities (but still greater than 50 percent) in the months of October through February when surface runoff is negligible (fig. 27B). The highest probabilities typically occurred in late March into midJuly because of spring and early summer runoff (fig. 27B). Compared to 1985 and 2015, the lowest FAEPs occurred in 2000, when the annual FAGMC was lowest and closest to the WQO (figs. $27 B$ and 21A); however, FAEPs were high (greater than 50 percent for most of the year) because the annual FAGMC remained greater than the WQO during the period (fig. 21A).

For total phosphorus, the annual mean FAEP increased from about 65 percent ( 237 days) in 1970 to about 85 percent (310 days) in 2015 (fig. 28A); therefore, concentrations were likely to be greater than the proposed WQO of $0.15 \mathrm{mg} / \mathrm{L}$ about 73 more days per year in 2015 than in 1970. Total phosphorus demonstrates a seasonal pattern similar to total nitrogen, and like total nitrogen, the seasonal pattern has been the same since 1985 (fig. 28B). The lowest FAEP occurs in the winter months (October-February) when surface runoff is negligible, and the highest FAEP occurs during April-September, after the beginning of the spring melt when surface runoff increases, and persisting though early fall. During AprilSeptember, the FAEP for total phosphorus was high (greater than about 0.9) during all three years shown, but by 2015, the FAEP was equal to 1 , indicating a near certainty of exceeding the WQO during those months (fig. 28B). The largest increases 

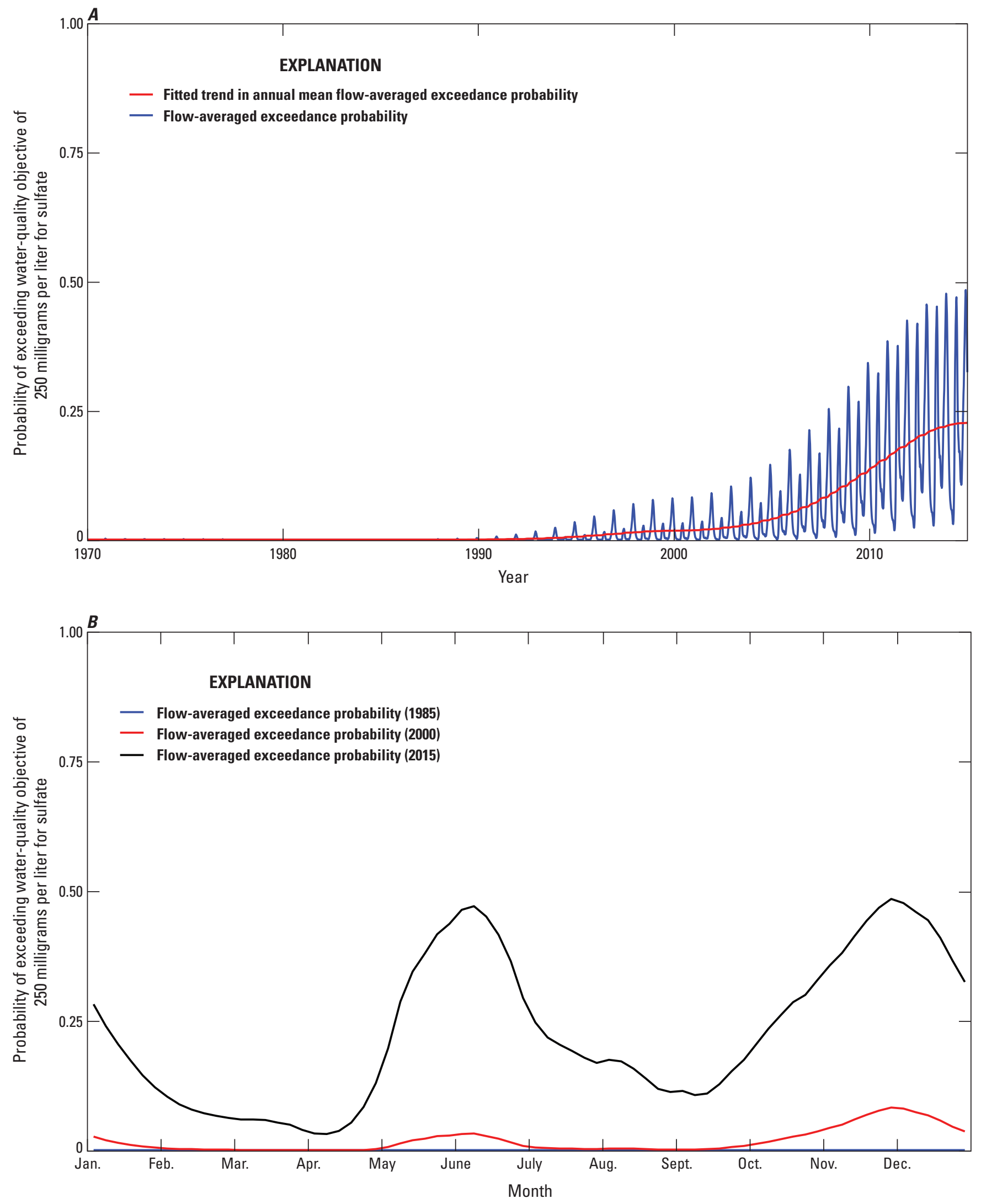

Figure 24. Flow-averaged exceedance probability and fitted trend in flow-averaged exceedance probability evaluated for the sulfate water-quality objective of 250 milligrams per liter at the binational site, Red River of the North at Emerson, Manitoba. $A$, for the historical period 1970-2015; B, for selected years 1985, 2000, and 2015. 

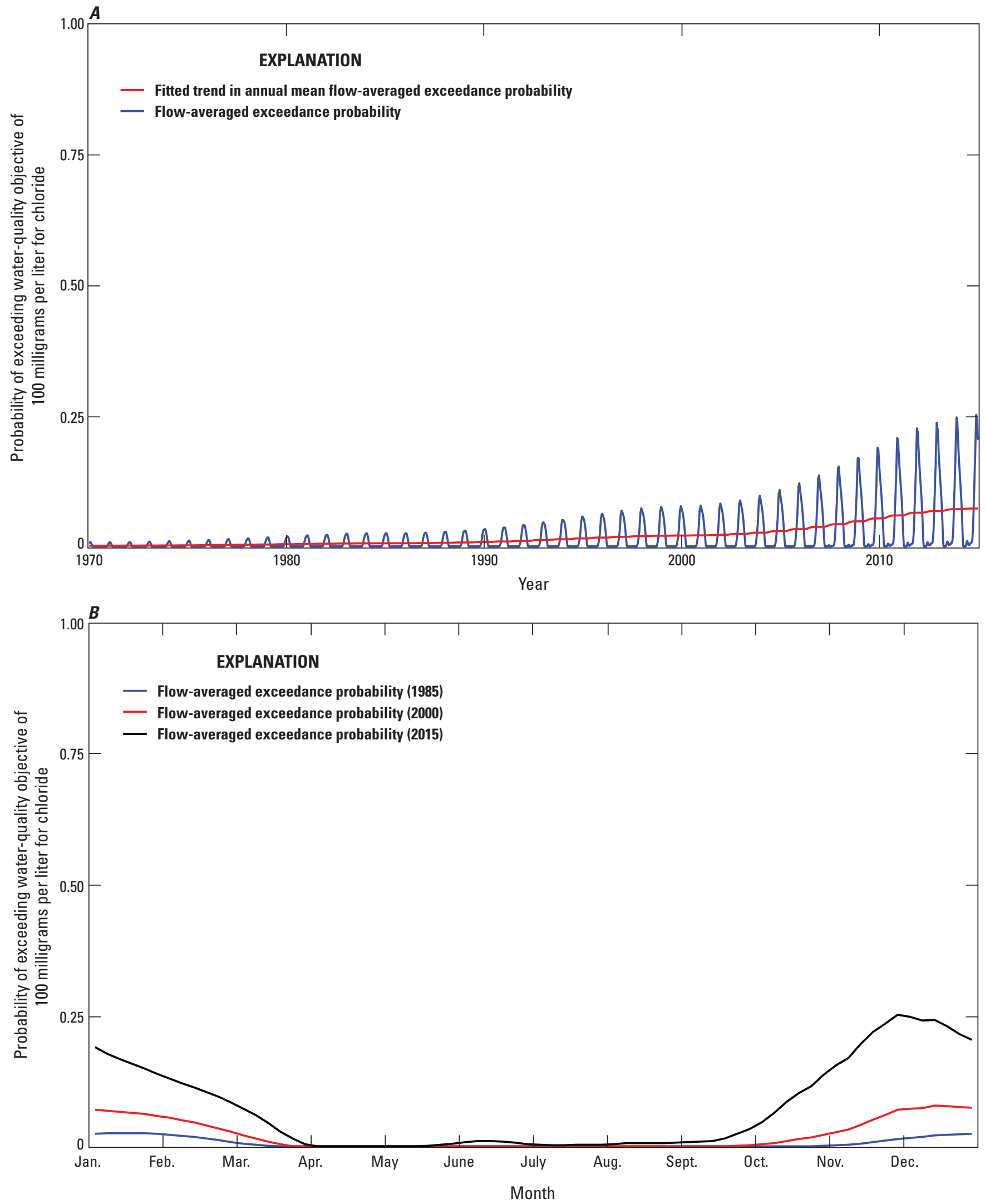

Figure 25. Flow-averaged exceedance probability and fitted trend in flow-averaged exceedance probability evaluated for the chloride water-quality objective of 100 milligrams per liter at the binational site, Red River of the North at Emerson, Manitoba. $A, 1970-2015 ; B$, for selected years 1985, 2000, and 2015. 

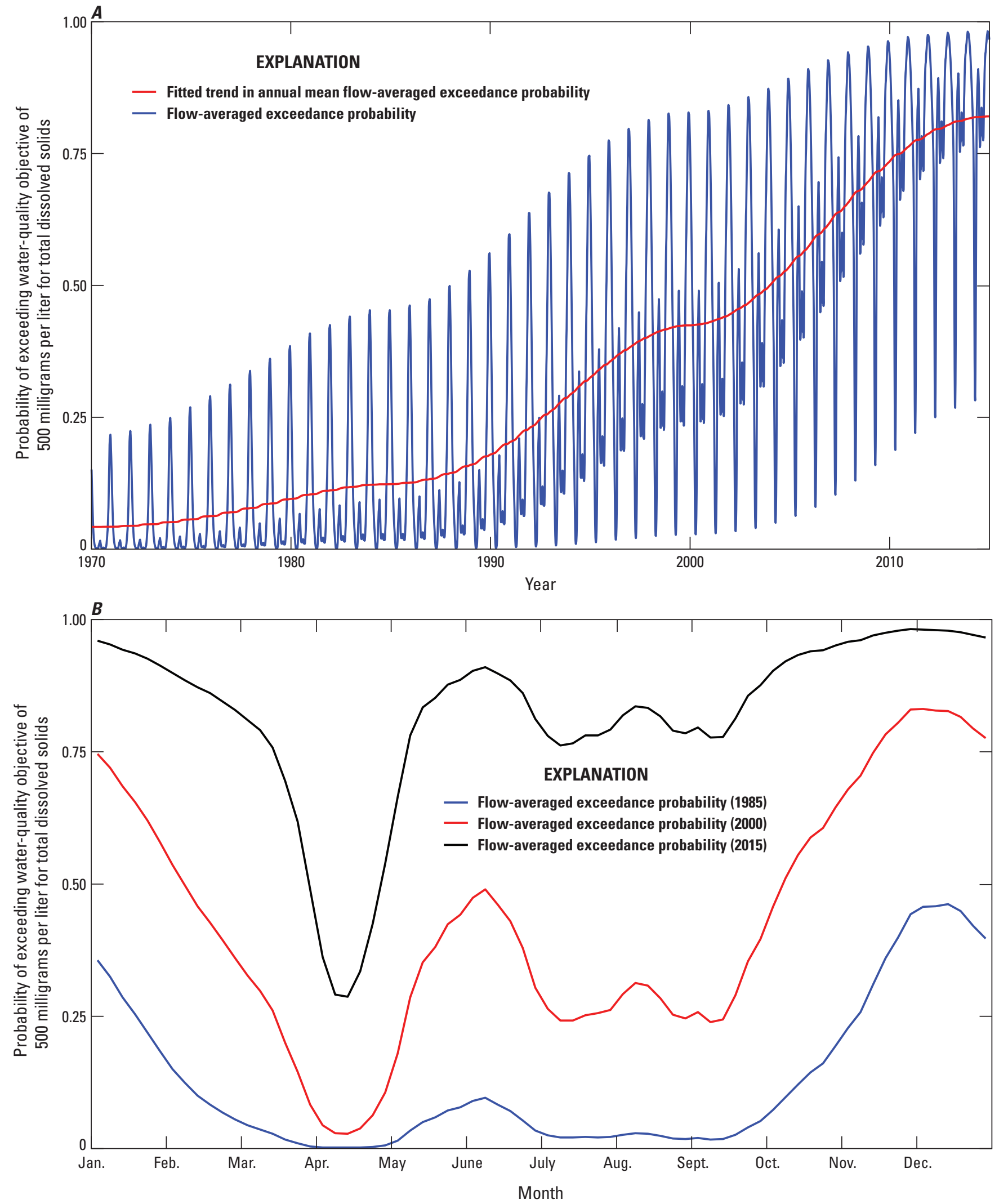

Figure 26. Flow-averaged exceedance probability and fitted trend in flow-averaged exceedance probability evaluated for the total dissolved solids water-quality objective of 500 milligrams per liter at the binational site, Red River of the North at Emerson, Manitoba. $A$, for the historical period 1970-2015; $B$, for selected years 1985, 2000, and 2015. 

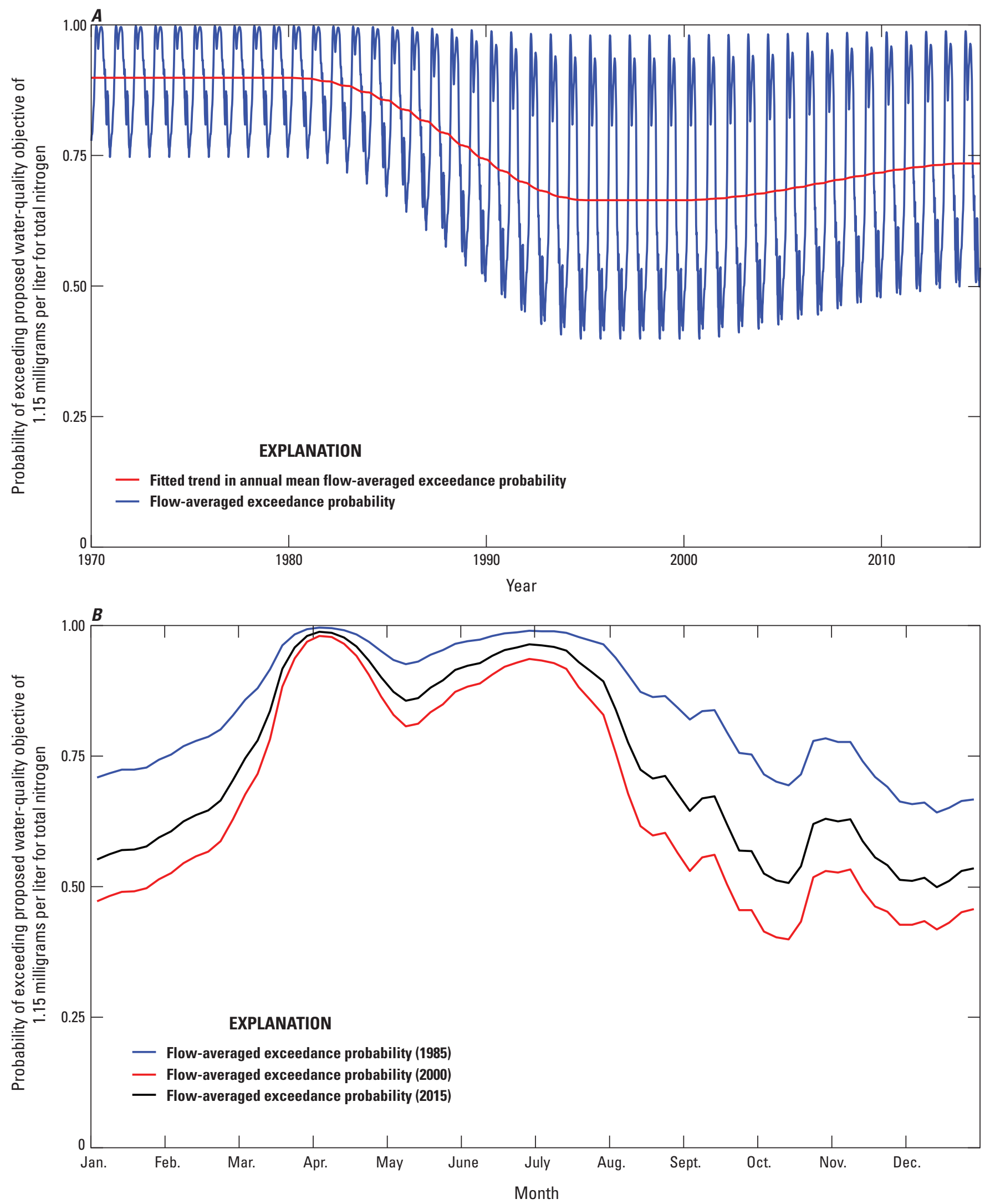

Figure 27. Flow-averaged exceedance probability and fitted trend in flow-averaged exceedance probability evaluated for the proposed total nitrogen water-quality objective of 1.15 milligrams per liter at the binational site, Red River of the North at Emerson, Manitoba. A, for the historical period 1970-2015; B, for selected years 1985, 2000, and 2015. 

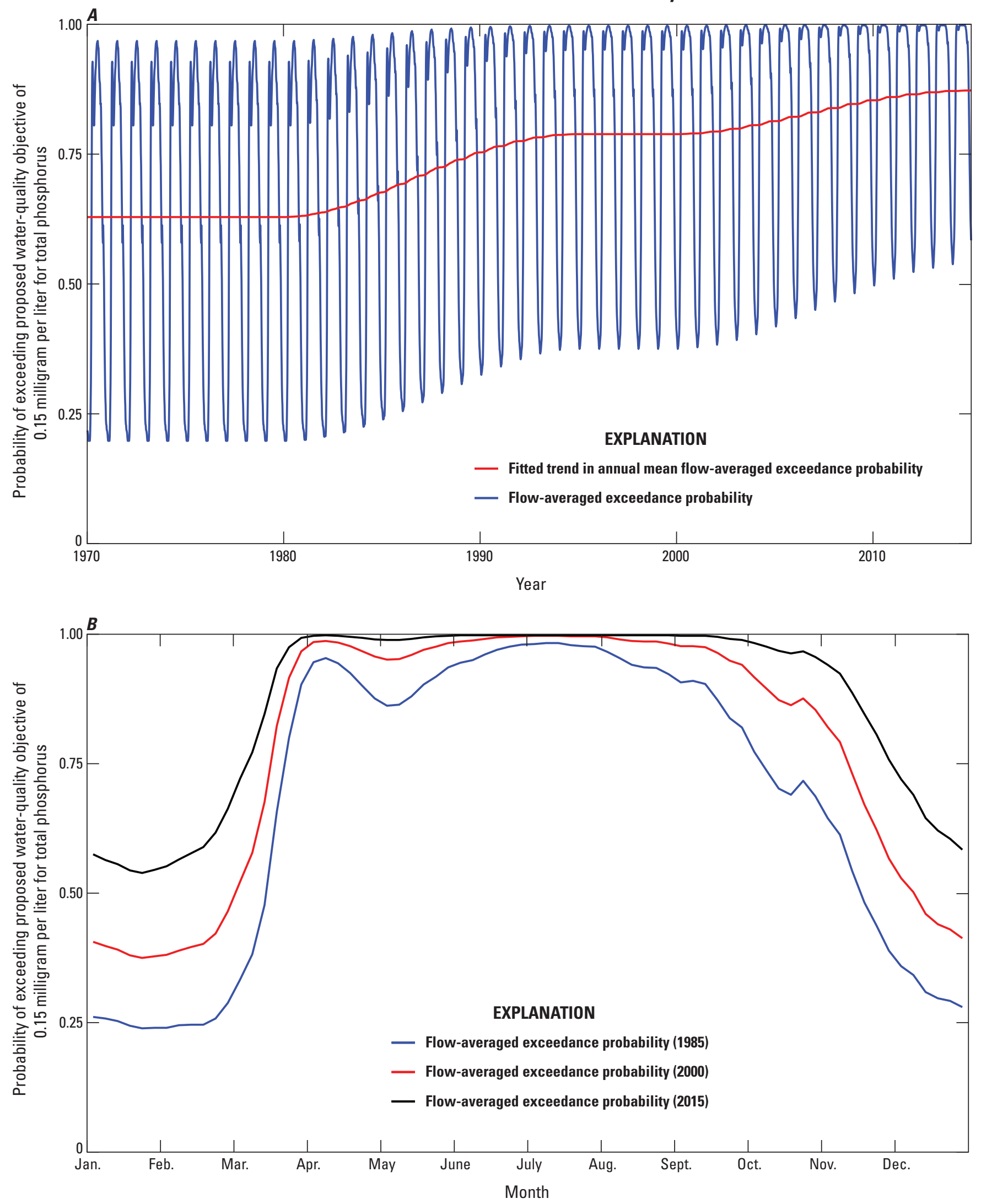

Figure 28. Flow-averaged exceedance probability and fitted trend in flow-averaged exceedance probability evaluated for the proposed total phosphorus water-quality objective of 0.15 milligram per liter at the binational site, Red River of the North at Emerson, Manitoba. A, for the historical period 1970-2015; B, for selected years 1985, 2000, and 2015. 
in FAEP occurred for the winter months. In 1985, there was about a 25-percent chance of exceeding the WQO during December-February, and in 2015, the chance more than doubled to about 60 percent.

\section{Implications of Trends and Future Research Needs}

Long-term (multidecadal), consistent monitoring for water quality and streamflow is essential to understanding spatial and temporal changes in water quality. The most valuable insight into temporal changes in water quality is gained through long-term water-quality programs that are efficiently designed to analyze trends and loads, include a comprehensive suite of analytes with consistent sampling frequencies, and have overlapping daily streamflow data from streamgages colocated with water-quality sampling sites. The trend-analysis tool used in the current study overcame many of the challenges of multiagency data, but the development of a consistent and efficiently designed water-quality monitoring network of a few indicator sites across the basin could help eliminate the data challenges detected here, reduce variability in the data, and provide benefits to agencies monitoring water quality in the basin.

Trend analysis is often used to address the basic question, "Is water quality getting better or worse?" As others have noted (Giorgino and others, 2018), this question is overly simplistic because water quality is affected by multiple, often confounding factors, making it difficult to pinpoint the drivers of change. Different basins undergoing the same natural (climatic variability) or human-induced changes (for example, population growth, agricultural activities, and artificial drainage) may have different changes in water quality because of differences in primary hydrologic flow paths and underlying physiography, geology, and soils (Capel and others, 2018). A better question of trend analysis is, "How have historical water-quality conditions changed through time and space (that is, among different subbasins)?" keeping in mind that changes may be occurring at different times and in different directions (trending "better" or "worse"). Only after describing how historical water-quality conditions have changed temporally and spatially can the important question, "Why is water quality changing?" be answered.

In the current study, water-quality data were compiled and trends were analyzed using a water-quality dataset from multiple agencies that collect water-quality data for various objectives, which presented multiple challenges for trend analysis. The trend-analysis approach was able to accommodate differences in water-quality data caused by field-collection and laboratory-analytical method differences, disparities in sampling frequencies, and spatial and temporal gaps in data. Most of these challenges were overcome by the statistical tool, R-QWTREND, which identifies trends in concentration unrelated to variability in streamflow. Field-collection differences and laboratory-analytical method differences among agencies for main-stem sites directly affected water-quality data, which in turn, affected trend results. To be confident that observed trends represented real environmental changes and not laboratory-analytical method or collection method differences, it was imperative to identify and address these differences. These differences were identified by investigating metadata for the water-quality samples, comparing data from similar sites, communicating with the collecting agencies, and applying step trends in R-QWTREND. The time-series model framework used in R-QWTREND accounts for variable sampling frequencies and short temporal data gaps; however, R-QWTREND may not be applicable for datasets with long temporal gaps or overly sparse sampling frequencies because the data may not be sufficient to estimate all the time-series model parameters. For guidelines on minimum data requirements for R-QWTREND, see Vecchia and Nustad (2020).

The integrated basin approach used in the current study, combined with comparing current data trends with historical trends, provided valuable insights into understanding how water quality is changing spatially (34 sites analyzed for 2000-15) and temporally (5 sites analyzed for a 45-year period, 1970-2015) within the Red River Basin. However, more detailed analysis is needed to confidently identify causes for the trends; for example, a mass balance approach that considers temporal and spatial variability in loads and concentrations in relation to spatial and temporal variability in potential causal factors is necessary. Within R-QWTREND, loads and concentrations are available, and trend attribution is completed by defining ancillary variables, which explain temporal and spatial variability in constituent load and concentration.

One of the most consistent spatial and temporal changes observed in the current study was increasing concentrations of sulfate among tributary and main-stem sites since 2000 . For some sites, increases were detected starting as early as 1985. Total dissolved solids and chloride concentrations had spatial and temporal patterns like sulfate. Loads for the Red River at Emerson, Manitoba, (site 26) increased by about 372,000 metric tons per year between 2000 and 2015 (table 5), which is equivalent to an increase on average in annual load of about 25,000 metric tons per year or an annual yield of about 0.25 metric ton per year per square kilometer. It is unlikely that human-induced change entirely can account for an increase of such large magnitude. As previously discussed, although R-QWTREND removes the variability in constituent concentration because of natural streamflow variability, all variability in sulfate caused by hydroclimatic variability may not be captured because of changes in hydrologic pathways and changes in the contributions of sulfate from various natural sources. In the Red River Basin, consistent increasing concentrations of sulfate, chloride, and total dissolved solids are likely linked to changes in the landscape, but natural hydroclimatic changes are also likely increasing the amount of salts reaching streams through surface and subsurface runoff. Determining the underlying cause for increasing sulfate would require further investigation into ancillary variables that reflect 
widespread (throughout much of the basin) natural or humaninduced changes that could increase the amount of naturally occurring sulfate reaching the streams from various hydrologic pathways and sources. Possible ancillary variables might include temporal and spatial changes in water-table elevations of shallow groundwater aquifers and associated increases in naturally occurring sulfate in shallow groundwater discharge, artificial surface or subsurface drainage improvements, and spatial soil characteristics. Explanatory variables for sulfate are also likely to be closely related to those for total dissolved solids and chloride.

Nutrient concentrations indicated less consistent spatial and temporal changes than sulfate, and changes in nutrient concentrations were assumed to be more closely tied to human-induced rather than natural changes. Nitrate-plusnitrite concentrations were mostly increasing in the upper Red River subbasin, and for nitrate plus nitrite and total nitrogen, the Sheyenne River subbasin had consistent decreasing concentrations. Since 2000, total phosphorus has decreased in the upper Red River subbasin, but the total phosphorus concentration has increased for sites in the lower Red River subbasin, and for some main-stem sites, concentrations have been increasing since 1985. Unlike sulfate, the pattern in historical trends for total phosphorus for the main-stem sites differed from tributary sites, indicating that human-induced changes affected tributaries and main-stem sites differently. Determining potential causes for changes in nutrients in specific subbasins requires further investigation. Dissolved phosphorus was not included in the current study, but analysis of dissolved phosphorus would provide some insight into the differences in total phosphorus between tributaries and mainstem sites and would provide some clues as to source and transport mechanisms. Potential ancillary variables to investigate for trend attribution of nutrients could include spatial and temporal changes in fertilizer application, manure application, feedlot operations, CRP acreage, subsurface drainage volume, wastewater effluent volumes, crop types, land-use change, population growth, or other measures of urban development.

The more detailed evaluation of water-quality conditions for the binational site, Red River at Emerson, Manitoba (site 26), provided an understanding of how loads have changed over time and what proportion of the year and season concentrations are expected to exceed WQOs, independent of variability in streamflow. In a basin with highly variable streamflow, like the Red River, the trend in flow-averaged load (assumes flow conditions are the same year after year) provided a robust measure of change over time. For example, a comparison of annual total nitrogen loads (not flow averaged) to the load target WQO indicated that during the drier period (before 1995), loads were mostly less than the WQO, but during the wetter period (2000-15), loads were greater than the WQO for most years, indicating that loads have increased during the wetter period. In contrast, a comparison of annual flow-averaged total nitrogen loads to the WQO indicated that loads decreased during the drier period, moving closer to the WQO, and during the wetter period, loads were virtually stable. The flow-averaged load is independent of streamflow variability and indicates that despite the higher streamflow years, annual flow-averaged total nitrogen loads have decreased. Similarly, exceedance probabilities were flow-averaged measures and, as such, allow for comparison in exceedances independent of streamflow. Increasing concentrations of sulfate, chloride, total dissolved solids, and total phosphorus since 1985 for the binational site resulted in increasing annual mean FAEP, meaning that longer periods of exceedance of WQOs per year were occurring over time. For total nitrogen, decreasing concentrations resulted in shorter periods of exceedance per year during 1980 to 2015, but concentrations were still expected to exceed the WQO about half the year. As indicated by the FAEP, periods of when exceedances were likely to occur during the year were affected by the source and transport mechanisms of the constituent; for example, chloride concentrations were most likely to exceed the WQO during winter months when groundwater contributions are largest. In contrast, the highest probability of exceedances for total nitrogen and total phosphorus typically occurred during spring to early summer when surface runoff is largest.

Trend results from this effort identified how water quality has changed across the basin, and further investigation would help to identify causes for the trends observed here. Information from the current study provides a basis for future trend attribution studies, evaluation of WQOs, and development of comprehensive strategies for reducing nutrients to desired targets and provides a baseline for tracking future progress in the Red River Basin.

\section{Summary}

A comprehensive study to evaluate water-quality trends, while considering natural hydroclimatic variability, in the Red River of the North Basin and assess water-quality conditions for the Red River of the North crossing the international boundary near Emerson, Manitoba, Canada (the binational site), was completed by the U.S. Geological Survey in cooperation with the International Joint Commission, North Dakota Department of Environmental Quality, and Minnesota Pollution Control Agency and in collaboration with Manitoba Sustainable Development and Environment and Climate Change Canada. The international Red River of the North Basin encompasses 3 U.S. States (South Dakota, North Dakota, and Minnesota), and 1 Canadian Province (Manitoba). Water quality in the Red River of the North is of concern for both Federal governments as well as State and Provincial governments. Water-quality objectives have been previously established for selected dissolved ions and recently (2019) proposed for selected nutrients for the binational site. To understand how water-quality conditions have changed in the Red River of the North Basin, an up-to-date (2015) integrated basin approach for assessing trends was needed, particularly one that accounts for changes in streamflow conditions. 
Long-term (multidecadal), consistent monitoring for water quality and streamflow is essential to understanding changes in water quality temporally and spatially. The most valuable insight into temporal changes in water quality is gained through long-term water-quality programs that are efficiently designed to analyze trends and loads, include a comprehensive suite of analytes with consistent sampling frequencies, and have overlapping daily streamflow data from colocated water-quality sampling sites. The trend-analysis tool used in the current (2020) study (R-QWTEND) overcame many of the challenges of multiagency data, but the development of a consistent and efficiently designed water-quality monitoring network of a few indicator sites across the basin could help eliminate the data challenges encountered here, reduce variability in the data, and provide benefits to agencies monitoring water quality in the basin.

Trend analysis is often used to address the basic question, "Is water quality getting better or worse?" As others have noted, this question is overly simplistic because water quality is affected by multiple, often confounding factors, making it difficult to pinpoint the drivers of change. Different basins undergoing the same natural (climatic variability) or humaninduced changes (for example, population growth, agricultural activities, and artificial drainage) may see different changes in water quality because of differences in primary hydrologic flow paths and underlying physiography, geology, and soils. A better question of trend analysis is, "How have historical water-quality conditions changed through time and space (that is, among different subbasins)?" keeping in mind that changes may be occurring at different times and in different directions (trending "better" or "worse"). Only after describing how historical water-quality conditions have changed temporally and spatially can the important question, "Why is water quality changing?" be answered.

In the current study (2020), water-quality data from State, Provincial, and Federal agencies in the United States and Canada for sites in the Red River of the North Basin from 1970 to 2017 were compiled and used for trend analysis. Trends analysis using a water-quality dataset from multiple agencies that collect water-quality data for various objectives presented multiple challenges. The trend-analysis approach was able to accommodate differences in water-quality data caused by field-collection and laboratory-analytical method differences, disparities in sampling frequencies, and spatial and temporal gaps in data. Most of these challenges were overcome by the statistical tool, R-QWTREND, which identifies trends in concentration unrelated to variability in streamflow. Field-collection differences and laboratory-analytical method differences among agencies for main-stem sites directly affected water-quality data, which in turn, affected trend results. To be confident that observed trends represented real environmental changes and not laboratory analytical method or collection method differences, it was imperative to identify and address these differences. These differences were identified by investigating metadata for the water-quality samples, comparing data from similar sites, communicating with the collecting agencies, and applying step trends in RQWTREND. The time-series model framework used in RQWTREND accounts for variable sampling frequencies and short temporal data gaps; however, R-QWTREND may not be applicable for datasets with long temporal gaps or overly sparse sampling frequencies because the data may not be sufficient to estimate all the time-series model parameters.

The integrated basin approach used in the current study, combined with comparing current data trends with historical trends, provided valuable insights into understanding how water quality is changing spatially (34 sites analyzed for a recent period, 2000-15) and temporally (5 sites analyzed for a 45-year historical period, 1970-2015) within the Red River of the North Basin. One of the most consistent spatial and temporal changes observed in the current study was increasing concentrations of sulfate among tributary and main-stem sites since 2000. For some sites, increases were detected starting as early as 1985 . Total dissolved solids and chloride concentrations had spatial and temporal patterns like sulfate. Although R-QWTREND removes the variability in constituent concentration caused by natural streamflow variability, all variability in sulfate caused by hydroclimatic variability may not be captured because of changes in hydrologic pathways and changes in the contributions of sulfate from various natural sources. In the Red River of the North Basin, consistent increasing concentrations of sulfate, chloride, and total dissolved solids are likely linked to changes in the landscape, but natural hydroclimatic changes are also likely increasing the amount of salts reaching streams through surface and subsurface runoff. Determining the underlying cause for increasing sulfate would require further investigation into ancillary variables that reflect widespread (throughout much of the basin) natural or humaninduced changes that could increase the amount of naturally occurring sulfate reaching the streams from various hydrologic pathways and sources.

Nutrient concentrations indicated less consistent spatial and temporal changes than sulfate, and changes in nutrient concentrations were assumed to be more closely tied to human-induced rather than natural changes. Nitrate-plusnitrite concentrations were mostly increasing in the upper Red River of the North subbasin, and for nitrate plus nitrite and total nitrogen, the Sheyenne River subbasin had consistent decreasing concentrations. Since 2000, total phosphorus has decreased in the upper Red River of the North subbasin, but total phosphorus concentration has increased for sites in the lower Red River of the North subbasin, and for some mainstem sites, concentrations have been increasing since 1985 . Unlike sulfate, the pattern in historical trends for total phosphorus for the main-stem sites differed from tributary sites, indicating that human-induced changes affected tributaries and main-stem sites differently. Determining potential causes for changes in nutrients in specific subbasins requires further investigation.

The more detailed evaluation of flow-averaged waterquality conditions for the binational site provided an understanding of how loads have changed over time and what 
proportion of the year and season concentrations are expected to exceed water-quality objectives, independent of variability in streamflow. In a basin with highly variable streamflow like the Red River of the North, the trend in flow-averaged load (assumes streamflow conditions are the same year after year) provided a robust measure of change over time. The flow-averaged load is independent of streamflow variability and indicates that despite higher streamflow years, annual flow-averaged nitrogen loads have decreased. Increasing concentrations of sulfate, chloride, total dissolved solids, and total phosphorus since 1985 for the binational site resulted in longer periods of exceedance of water-quality objectives per year occurring over time. For total nitrogen, decreasing concentrations resulted in shorter periods of exceedance per year during 1980 to 2015, but concentrations were still expected to exceed the water-quality objective about half the year. Periods of when exceedances were likely to occur during the year were affected by the source and transport mechanisms of the constituent; for example, for chloride, concentrations were most likely to exceed the water-quality objective during winter months when groundwater contributions are largest. In contrast, the highest probability of exceedances for total nitrogen and total phosphorus typically occurred during spring to early summer when surface runoff is largest.

Trend results from this effort identified how water quality has changed across the basin, and further investigation would help to identify causes for the trends observed here. Information from the current study provides a basis for future trend attribution studies, evaluation of water-quality objectives, and development of comprehensive strategies for reducing nutrients to desired targets and provides a baseline for tracking future progress in the Red River of the North Basin.

\section{References Cited}

Capel, P.D., McCarthy, K.A., Coupe, R.H., Grey, K.M., Amenumey, S.E., Baker, N.T., and Johnson, R.L., 2018, Agriculture - A river runs through it-The connections between agriculture and water quality: U.S. Geological Survey Circular 1433, 201 p. [Also available at https://doi.org/10.3133/cir1433.]

Corsi, S.R., De Cicco, L.A., Lutz, M.A., and Hirsch, R.M., 2015, River chloride trends in snow-affected urban watersheds - Increasing concentrations outpace urban growth rate and are common among all seasons: The Science of the Total Environment, v. 508, no. 1, p. 488-497. [Also available at https://doi.org/10.1016/ j.scitotenv.2014.12.012.]
Dubrovsky, N.M., Burow, K.R., Clark, G.M., Gronberg, J.M., Hamilton, P.A., Hitt, K.J., Mueller, D.K., Munn, M.D., Nolan, B.T., Puckett, L.J., Rupert, M.G., Short, T.M., Spahr, N.E., Sprague, L.A., and Wilber, W.G., 2010, The quality of our Nation's waters-Nutrients in the Nation's streams and groundwater, 1992-2004: U.S. Geological Survey Circular 1350, 174 p. [Also available at https://water.usgs.gov/nawqa/nutrients/pubs/circ1350.]

Environment Canada and Manitoba Water Stewardship, 2011, State of Lake Winnipeg - 1999 to 2007:

Manitoba, Environment Canada and Manitoba Water Stewardship, 222 p., accessed February 6, 2020, at https://mspace.lib.umanitoba.ca/handle/1993/23915.

Franzen, D., 2007, Managing saline soils in North Dakota: North Dakota State University Extension Service SF-1087 (revised September 2019), 12 p.

Gabriel, M., and Benoy, G., 2016, A review of international water quality objectives in the Souris, Red, Rainy-Lake of the Woods and St. Croix River Basins--Historical perspectives, trends and future directions: International Joint Commission, $61 \mathrm{p}$.

Galloway, J.M., Vecchia, A.V., Vining, K.C., Densmore, B.K., and Lundgren, R.F., 2012, Evaluation of water-quality characteristics and sampling design for streams in North Dakota, 1970-2008: U.S. Geological Survey Scientific Investigations Report 2012-5216, 304 p. [Also available at https://doi.org/10.3133/sir20125216.]

Giorgino, M.J., Cuffney, T.F., Harden, S.L., and Feaster, T.D., 2018 , Trends in water quality of selected streams and reservoirs used for water supply in the Triangle area of North Carolina, 1989-2013: U.S. Geological Survey Scientific Investigations Report 2018-5077, 67 p. [Also available at https://doi.org/10.3133/sir20185077.]

Gray, J.R., Glysson, G.D., Turcios, L.M., and Schwarz, G.E., 2000, Comparability of suspended-sediment concentration and total suspended solids data: U.S. Geological Survey Water-Resources Investigations Report 00-4191, 14 p. [Also available at https://doi.org/10.3133/wri004191.]

Helsel, D.R., and Hirsch, R.M., 2002, Statistical methods in water resources: U.S. Geological Survey Techniques of Water-Resources Investigations, book 4, chap. A3, 510 p., accessed May 2020 at https://doi.org/10.3133/twri04A3.

Hem, J.D., 1985, Study and interpretation of the chemical characteristics of natural water: U.S. Geological Survey Water-Supply Paper 2254, 263 p. [Also available at https://doi.org/10.3133/wsp2254.] 
International Joint Commission, 2019, The International Red River Board: Esri web page, accessed November 25, 2019, at https://ijc.maps.arcgis.com/home/group.html?id= 7cf963a4dd2442f38235248b2f88bf9f\#overview.

International Red River Board, 2011, A proposed approach to developing a basin-wide nutrient management strategy for the international red river watershed: International Red River Board, 5 p., accessed June 2020 at https://ijc.org/en/ $\mathrm{rrb} /$ proposed-approach-developing-basin-wide-nutrientmanagement-strategy-international-red-river.

International Red River Board, 2019, Letter from IRRB to IJC commissioners-Recommendation of nutrient objectives and targets for the Red River: International Red River Board web page, accessed June 2020 at https://ijc.org/en/ $\mathrm{rrb} /$ proposed-nutrient-concentration-objectives-and-loadingtargets-red-river-uscanada-boundary.

Jones, G., and Armstrong, N., 2001, Long-term trends in total nitrogen and total phosphorus concentrations in Manitoba streams: Winnipeg, Manitoba Conservation Report no. 2001-07, $175 \mathrm{p}$.

Kaushal, S.S., Likens, G.E., Pace, M.L., Utz, R.M., Haq, S., Gorman, J., and Grese, M., 2018, Freshwater salinization syndrome on a continental scale: Proceedings of the National Academy of Sciences of the United States of America, v. 115, no. 4, p. E574-E583, accessed September 5, 2019, at https://doi.org/10.1073/ pnas. 1711234115 .

Kolars, K.A., Vecchia, A.V., and Ryberg, K.R., 2015, Stochastic model for simulating Souris River precipitation, evapotranspiration, and natural streamflow: U.S. Geological Survey Scientific Investigations Report 2015-5185, 55 p., accessed May 2020 at https://doi.org/10.3133/sir20155185.

National Water Quality Monitoring Council, 2019, Water Quality Portal: National Water Quality Monitoring Council web page, accessed October 31, 2019, at https://www.waterqualitydata.us.

North Dakota State Water Commission, 2019a, Devils Lake by the numbers: North Dakota State Water Commission Fact Sheet, 4 p., accessed September 19, 2019, at https://www.swc.nd.gov/pdfs/dl_fact_sheet.pdf.

North Dakota State Water Commission, 2019b, August 2019 Devils Lake outlets monthly discharge and water quality report: Bismarck, N. Dak., North Dakota State Water Commission, 13 p., accessed November 2, 2019, at https://www.swc.nd.gov/basins/devils_lake/outlets/ discharge_monitoring/pdfs/2019_08.pdf.
Nustad, R.A., 2020, Water-quality and streamflow data for United States and Canadian sites in the Red River Basin and scripts for trend analysis-Data supporting waterquality trend analysis in the Red River of the North Basin, 1970-2017: U.S. Geological Survey data release, https://doi.org/10.5066/P9C9JAMY.

Oblinger Childress, C.J., Foreman, W.T., Connor, B.F., and Maloney, T.J., 1999, New reporting procedures based on long-term method detection levels and some considerations for interpretations of water-quality data provided by the U.S. Geological Survey National Water Quality Laboratory: U.S. Geological Survey Open-File Report 99-193, 19 p. [Also available at https://doi.org/10.3133/ofr99193.]

Oelsner, G.P., Sprague, L.A., Murphy, J.C., Zuellig, R.E., Johnson, H.M., Ryberg, K.R., Falcone, J.A., Stets, E.G., Vecchia, A.V., Riskin, M.L., De Cicco, L.A., Mills, T.J., and Farmer, W.H., 2017, Water-quality trends in the Nation's rivers and streams, 1972-2012-Data preparation, statistical methods, and trend results (ver. 2.0, October 2017): U.S. Geological Survey Scientific Investigations Report 2017-5006, 136 p., accessed May 2020 at https://doi.org/10.3133/sir20175006.

Paquette, C., 2011, Statistical analysis of trends in the Red River over a 45-year period, University of Manitoba, master's thesis, $115 \mathrm{p}$.

Risch, M.R., Bunch, A.R., Vecchia, A.V., Martin, J.D., and Baker, N.T., 2014, Water quality in Indiana-Trends in concentrations of selected nutrients, metals, and ions in streams, 2000-10: U.S. Geological Survey Scientific Investigations Report 2014-5205, 47 p. [Also available at https://doi.org/10.3133/sir20145205.]

Ryberg, K.R., Vecchia, A.V., Akyüz, F.A., and Lin, W., 2016, Tree-ring based estimates of long-term seasonal precipitation in the Souris River region of Saskatchewan, North Dakota, and Manitoba: Journal of the Canadian Water Resources Association, v. 41, no. 3, p. 412-428. [Also available at https://doi.org/10.1080/07011784.2016.1164627.]

Sando, S.K., Clark, M.L., Cleasby, T.E., and Barnhart, E.P., 2015, Water-quality trends for selected sites in the Boulder River and Tenmile Creek watersheds, Montana, based on data collected during water years 1997-2013: U.S. Geological Survey Scientific Investigations Report 2015-5008, 46 p., accessed May 2020 at https://doi.org/10.3133/sir20155008.

Sando, S.K., Vecchia, A.V., Lorenz, D.L., and Barnhart, E.P., 2014a, Water-quality trends for selected sampling sites in the upper Clark Fork Basin, Montana, water years 1996-2010: U.S. Geological Survey Scientific Investigations Report 2013-5217, 162 p. [Also available at https://doi.org/10.3133/sir20135217.] 
Sando, S.K., Vecchia, A.V., Barnhart, E.P., Sando, T.R., Clark, M.L., and Lorenz, D.L., 2014b, Trends in majorion constituents and properties for selected sampling sites in the Tongue and Powder River watersheds, Montana and Wyoming, based on data collected during water years 1980-2010: U.S. Geological Survey Scientific Investigations Report 2013-5179, 123 p. [Also available at https://doi.org/10.3133/sir20135179.]

Schuh, W.M., and Hove, M.H., 2006, Sources and processes affecting dissolved sulfate concentrations in the Upper Sheyenne River: North Dakota State Water Commission, Water Resources Investigations no. 60, 53 p.

Stets, E.G., Lee, C.J., Lytle, D.A., and Schock, M.R., 2018, Increasing chloride in rivers of the conterminous U.S. and linkages to potential corrosivity and lead action level exceedances in drinking water: The Science of the Total Environment, v. 613-614, no. 1, p. 1498-1509. [Also available at https://doi.org/10.1016/j.scitotenv.2017.07.119.]

Stoner, J.D., Lorenz, D.L., Wiche, G.J., and Goldstein, R.M., 1993, Red River of the North Basin, Minnesota, North Dakota, and South Dakota: Water Resources Bulletin, v. 29, no. 4, p. 575-615. [Also available at https://doi.org/10.1111/ j.1752-1688.1993.tb03229.x.]

Tornes, L.H., 2005, Water quality of streams in the Red River of the North Basin, Minnesota, North Dakota, and South Dakota, 1970-2001: U.S. Geological Survey Scientific Investigations Report 2005-5095, 88 p. [Also available at https://doi.org/10.3133/sir20055095.]

Tornes, L.H., and Brigham, M.E., 1993, Nutrients, suspended sediment, and pesticides in waters of the Red River of the North Basin, Minnesota, North Dakota, and South Dakota, 1970-90: U.S. Geological Survey Water Resources Investigations Report 93-4231, 70 p. [Also available at https://doi.org/10.3133/wri934231.]

University of Minnesota Extension, 2019, Subsurface drainage in the Red River Valley: University of Minnesota Extension web page, accessed November 27, 2019, at https://extension.umn.edu/agricultural-drainage/subsurfacedrainage-red-river-valley.

U.S. Geological Survey, 2019, USGS water data for the Nation: U.S. Geological Survey National Water Information System database, accessed October 31, 2019, at https://doi.org/10.5066/F7P55KJN.

Vecchia, A.V., 2000, Water-quality trend analysis and sampling design for the Souris River, Saskatchewan, North Dakota, and Manitoba: U.S. Geological Survey WaterResources Investigations Report 2000-4019, 77 p. [Also available at https://doi.org/10.3133/wri004019.]
Vecchia, A.V., 2003, Water-quality trend analysis and sampling design for streams in North Dakota: U.S. Geological Survey Water-Resources Investigations Report 2003-4094, 73 p. [Also available at https://doi.org/10.3133/wri034094.]

Vecchia, A.V., 2005, Water-quality trend analysis and sampling design for streams in the Red River of the North Basin, Minnesota, North Dakota, and South Dakota, 1970-2001: U.S. Geological Survey Scientific Investigations Report 2005-5224, 54 p. [Also available at https://doi.org/10.3133/ sir20055224.]

Vecchia, A.V., 2008, Climate simulation and flood risk analysis for 2008-40 for Devils Lake, North Dakota: U.S. Geological Survey Scientific Investigations Report 2008-5011, 28 p. [Also available at https://doi.org/10.3133/ sir20085011.]

Vecchia, A.V., and Nustad, R.A., 2020, Time-series model, statistical methods, and software documentation for R-QWTREND - An R package for analyzing trends in stream-water quality: U.S. Geological Survey OpenFile Report 2020-1014, 51 p., accessed May 2020 at https://doi.org/10.3133/ofr20201014. 



\section{Appendix 1. Special Consideration-Devils Lake Outlets}

A special consideration in evaluating trends for the Sheyenne River (sites 7-11; fig. 1 and table 1 of main report) and the Red River of the North (hereafter referred to as the "Red River") main-stem sites downstream from the Sheyenne River (sites 15, 20, 23, 26; fig. 1 and table 1 of main report) was potential changes to water quality related to the Devils Lake outlets. Devils Lake outlets were constructed by the State of North Dakota, in response to a more than 30-foot lake level rise between 1993 and 2011, to discharge water from Devils Lake to the Sheyenne River (North Dakota State Water Commission, 2019a). The West End Outlet was operational in 2005 but did not start discharging until 2008. The East End Outlet started discharging in 2012. Devils Lake, a naturally closed lake basin, has higher concentrations of ions, especially sulfate, compared to the Red River (Vecchia, 2008). Sulfate is the main concern for downstream water bodies because concentrations from the East End Outlet discharges are typically about 1,000 milligrams per liter $(\mathrm{mg} / \mathrm{L})$ and, from the West End Outlet, about $600 \mathrm{mg} / \mathrm{L}$ compared with a median concentration of $187 \mathrm{mg} / \mathrm{L}$ for Red River main-stem site 15 (fig. 1 and table 2 of main report; North Dakota State Water Commission, 2019b). Water-quality changes related to the outlets were addressed by applying a user-specified ancillary trend variable in R-QWTREND (Vecchia and Nustad, 2020) to remove the effects of the outlets. Effects of the outlets on nutrient and total suspended solids concentrations were determined to be negligible, but for sulfate, chloride, and total dissolved solids, changes because of the outlet were identified and removed before analyzing trends. Hereafter "with outlet" refers to values and conditions with the effects of the outlets and "no outlet" refers to the values and conditions with the effects of the outlets removed. The methods used for removing the effects of the Devils Lake outlets, and the effects of the outlet on dissolved ions concentrations, are described in detail in this appendix.

To model the effect of the Devils Lake outlets on downstream concentrations of dissolved ions (sulfate, chloride, and total dissolved solids), we assume these constituents are conservative, which means that the concentration can be expressed as follows:

$$
C_{o}=\left[C_{n} Q_{n}+C_{W D L} Q_{W D L}+C_{E D L} Q_{E D L}\right] / Q_{o}
$$

where

$$
\begin{aligned}
& C_{o} \text { is the observed (with-outlet) concentration, in } \\
& \text { milligrams per liter; } \\
& C_{n} \quad \text { is the natural (no-outlet) concentration, in } \\
& \text { milligrams per liter; } \\
& Q_{n} \quad \text { is equal to } Q_{o}-Q_{W D L}-Q_{E D L} \text { and is the no-outlet } \\
& \text { streamflow, in cubic feet per second; } \\
& C_{W D L} \text { is the concentration for the West End Outlet, } \\
& \text { in milligrams per liter; } \\
& Q_{W D L} \quad \text { is the flow from the West End Outlet, in cubic }
\end{aligned}
$$

$$
\begin{array}{cc}
C_{E D L} & \begin{array}{c}
\text { is the concentration for the East End Outlet, in } \\
\text { milligrams per liter; }
\end{array} \\
Q_{E D L} & \begin{array}{c}
\text { is the flow from the East End Outlet, in cubic } \\
\text { feet per second; and }
\end{array} \\
Q_{o} \quad \begin{array}{c}
\text { is the with-outlet streamflow, in cubic feet } \\
\text { per second. }
\end{array}
\end{array}
$$

Concentrations for the West and East End Outlets were assumed to be relatively constant for the 10-year period 2008-18, and the West End Outlet concentration was assumed to be about one-half of the East End Outlet concentration (Vecchia, 2008; North Dakota State Water Commission, 2019b):

$$
C_{W D L}=0.5 C_{E D L}
$$

Substituting equation 1.2 into equation 1.1 and simplifying results in the following.

$$
\begin{gathered}
C_{o}=C_{n}\left\{1-\left(Q_{W D L}+Q_{E D L}\right) / Q_{o}\right. \\
\left.+\left[C_{E D L} / C_{n}\right]\left[0.5 Q_{W D L}+Q_{E D L}\right] / Q_{o}\right\}
\end{gathered}
$$

Next, the total volume from the outlets, $Q_{W D L}+Q_{E D L}$, can be expressed in terms of the reduced volume from the outlets, $0.5 Q_{W D L}+Q_{E D L}$, as follows:

$$
Q_{W D L}+Q_{E D L}=M\left[0.5 Q_{W D L}+Q_{E D L}\right]
$$

where

$$
\begin{aligned}
& M \quad \text { is }\left(Q_{W D L}+Q_{E D L}\right) /\left[0.5 Q_{W D L}+Q_{E D L}\right], \text { if } \\
& 0.5 Q_{W D L}+Q_{E D L}>0, \text { and } \\
& M \quad \text { is } 0, \text { if } 0.5 Q_{W D L}+Q_{E D L}=0 .
\end{aligned}
$$

Note that, for times when the total discharge from the outlets is not zero, $1 \leq M \leq 2$. Combining equations 1.3 and 1.4 results in the following.

$$
C_{o}=C_{n}\left\{1+\left[C_{E D L} / C_{n}-M\right]\left[0.5 Q_{W D L}+Q_{E D L}\right] / Q_{o}\right\}
$$

Next, note that

$$
R_{D L}=\left[0.5 Q_{W D L}+Q_{E D L}\right] / Q_{o}<1
$$

where

$R_{D L} \quad$ is a ratio of Devils Lake outlets discharge to total streamflow.

For downstream sites on the main stem of the Red River (where $Q_{n}$ tends to be large relative to the discharge from the outlets), $R_{D L}$ tends to be much less than 1 . Combining equations 1.5 and 1.6 and using the linear approximation to the logarithmic transform,

$$
\log (1+A x) \sim 0.23 A x \text {, for } 0 \leq x \leq 1,
$$

where

$$
\text { A is an arbitrary constant and }
$$


$x \quad$ is a real number between 0 and 1 , results in the approximation

$$
\log C_{o} \sim \log C_{n}+\lambda R_{D L}
$$

where

$$
\lambda \quad \text { is equal to } 0.23\left(C_{E D L} / C_{n}-M\right) \text {. }
$$

From equation 1.8 , to a good approximation, logarithmically transformed with-outlet concentration is equal to logarithmically transformed no-outlet concentration plus a coefficient, $\lambda$, times the flow ratio (eq. 1.6). Provided $C_{E D L}$ is at least twice as high as the no-outlet concentration (which is true for all the downstream sites), $\lambda$ is positive and the withoutlet concentration is either equal to (if $x=0$ ) or greater than (if $x>0$ ) the no-outlet concentration.

Substituting the time-series model for logarithmically transformed no-outlet concentration (Vecchia and Nustad, 2020) into equation 1.8 results in

$$
\log C_{o}=F R V_{n}+T R_{n}+\lambda R_{D L}+E
$$

where

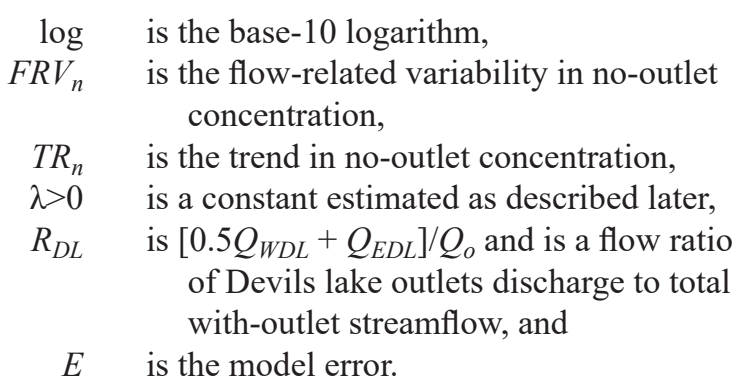

Therefore, the trend model for with-outlet concentration was obtained by including the flow ratio, $R_{D L}$, as an ancillary (userdefined) trend variable in the model for no-outlet concentration, and the trend coefficient, $\lambda$, was estimated for each site and constituent combination along with the trend in no-outlet concentration. The no-outlet trend results reported in the main body of this report are for the adjusted concentrations,

$$
\log C_{n}=\log C_{o}-\lambda R_{D L}=F R V_{n}+T R_{n}+E
$$

For each 5-day model time step, $t$, and for each of the sites affected by discharges from the outlets, Sheyenne River sites 7-11 and Red River sites 15, 20, 23, and 26 (fig. 1 of main report), the known Devils Lake outlets discharges for the outlets discharge locations on the Sheyenne River were used along with a flow-routing algorithm to estimate the downstream flow ratios,

$$
\begin{aligned}
& R_{D L}\left(s_{d} ; t_{d}\right)=\text { Function }\left\{Q_{n}\left(s_{u} ; t_{u}\right),\right. \\
& \left.Q_{W D L}\left(s_{u} ; t_{u}\right), Q_{E D L}\left(s_{u}, t_{u}\right), t_{u} \leq t_{d}\right\}
\end{aligned}
$$

where

\footnotetext{
$s_{d} \quad$ is a designated site downstream from the Devils Lake outlets, $t_{d} \quad$ is a designated 5-day time step for the
}

\author{
downstream site, \\ $s_{u} \quad$ is the nearest upstream site, and \\ $t_{u} \quad$ is the 5-day time step for the nearest \\ upstream site.
}

The flow-routing algorithm accounts for lagged travel times for water from the outlets to mix with natural streamflow for the upstream site and reach the downstream site before mixing with additional natural streamflow for the intervening reach. The algorithm is similar to the algorithm described in Vecchia (2008). For the first downstream site on the Sheyenne River (site 7), $Q_{W D L}$ consists of West End Outlet discharge lagged by one time step ( 5 days), and $Q_{E D L}$ is zero. For the next downstream site (site 8), $Q_{W D L}$ consists of West End Outlet discharge lagged by two time steps (10 days), and $Q_{E D L}$ consists of East End Outlet discharge lagged by one time step. For the next downstream site (site 9), a conceptual reservoir storage model was used to approximate the effect of storage in Lake Ashtabula given no-outlet inflow and inflow from the Devils Lake outlets (estimated using $Q_{n}, Q_{W D L}$, and $Q_{E D L}$ for site 8$)$. After using the conceptual storage model to compute $Q_{W D L}$ and $Q_{E D L}$ for site 9 , these flows were lagged by one additional time step for each of the subsequent sites $(10,11$, $15,20,23$, and 26).

The flow ratios, $R_{D L}$, for the farthest downstream site on the Sheyenne River (site 11) and Red River (sites 15 and 26) are shown in figure 1.1 (flow ratios before 2005 are equal to zero because the outlets were not operating). Flow ratios for site 11 ranged from about 0 to 0.8 . The largest values (greater than 0.4 ) occurred during most years from about early July through the following February, and much smaller values (less than about 0.1 ) occurred during spring high flow conditions (generally March through June). For Red River site 15, the ratio ranged from about 0 to 0.4 , except in late 2012 and early 2013, when the ratio reached about 0.6. Larger values (greater than 0.2 ) tended to occur during late July through December, with much smaller values (less than about 0.05) during March through June. For the binational site (site 26), the ratio ranged from about 0 to 0.25 , except during 2012, when it reached about 0.5 . Larger values (greater than 0.1 ) occurred from early August through December, with much smaller values (less than 0.05) during March through June.

As indicated by figure 1.1, the flow ratios, and hence, the relative effects of the Devils Lake outlets on downstream concentrations, are highly dependent on the location and time of year. To discuss the effects of the outlets, it is useful to define two additional equations (see Vecchia and Nustad, 2020). The first is flow-adjusted concentrations:

$$
F A D J C_{o}=\log C_{o}-F R V_{n}=T R_{n}+\lambda R_{D L}+E
$$

where

$$
\begin{aligned}
& F A D J C_{O} \quad \text { is the flow-adjusted (with-outlet) } \\
& \text { concentration (equivalent to eq. } 7 \text { in } \\
& \text { Vecchia and Nustad, 2020). }
\end{aligned}
$$




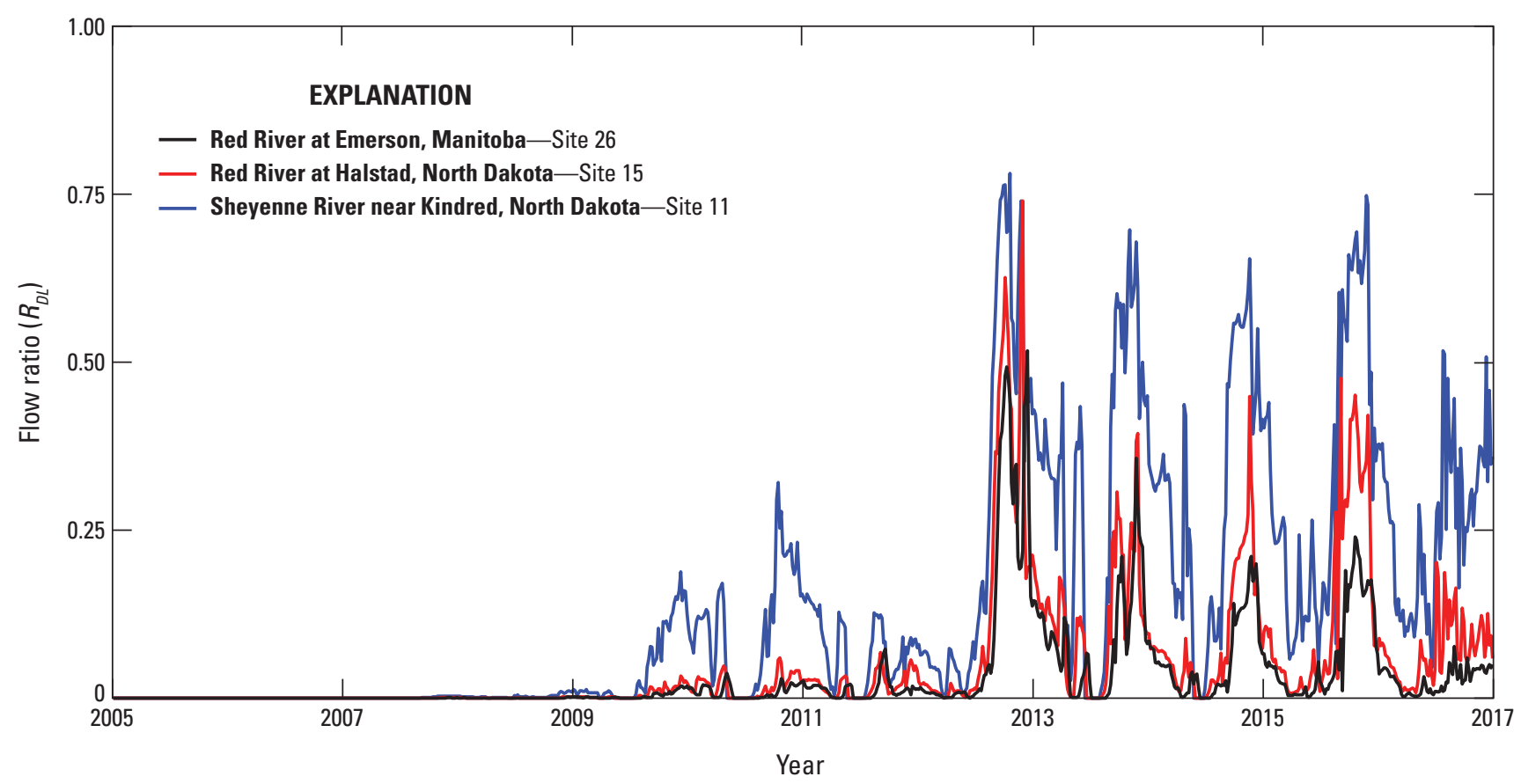

Figure 1.1. Flow ratios for Sheyenne River near Kindred, North Dakota (site 11); Red River at Halstad, Minnesota (site 15); and Red River at Emerson, Manitoba (site 26), used as an ancillary trend variable in R-OWTREND to evaluate trends in sulfate, chloride, and total dissolved solids concentrations under "no-outlet conditions" (without Devils Lake outlets).

The flow-adjusted concentration is obtained by removing all (seasonal and interannual) flow-related variability and is useful for examining the trends in relation to the background noise $(E)$. The second equation is flow-averaged concentration:

$$
F A V E C_{o}=S\left\{F R V_{n}\right\}+T R_{n}+\lambda R_{D L}+S B C F
$$

where

$F A V E C_{o}$ is the flow-averaged concentration,

$S\left\{F R V_{n}\right\} \quad$ is seasonal flow-related variability, and $S B C F \quad$ is a seasonal bias correction factor.

The flow-averaged concentration is obtained by removing interannual flow-related variability but not seasonal flowrelated variability and replacing the error with a bias correction factor because of the logarithmic transform. The seasonal flow-related variability for a given time step $(t)$ is interpreted as the hypothetical variability that would be observed under "normal" seasonal streamflow conditions for the time step; for example, if $t$ corresponds to June 1 of a given year, streamflow is assumed to be equal to the average of the daily streamflow values for June 1 for all years in the period of analysis. The flow-averaged concentration is useful for computing unbiased estimates of various statistics used for trend analysis. For example, one such statistic is the annual (flow-averaged) geometric mean concentration:

$$
F A G M C_{y}=\text { Mean }\left\{F A V E C_{o}(t), t \text { in } y\right\}
$$

where

$$
F A G M C_{y} \quad \text { is the annual flow-averaged geometric mean }
$$
concentration;

Mean $\{$.$\} \quad is the mean of the values in braces for all time$ point, $t$, in year $y$;; and

$y \quad$ is a specified calendar year.

The flow-adjusted concentrations and fitted trend (eq. 1.12) for sulfate concentration for sites 11 and 26 are shown in figure 1.2. The points in this figure correspond to $F A D J C_{o}$ and the line corresponds to $T R_{n}+\lambda R_{D L}$. For both sites, the trend in natural (no-outlet) concentration, $T R_{n}$, consisted of a significant monotonic increase from 2000 to 2015. Flow-adjusted sulfate concentrations increased from about 225 to $300 \mathrm{mg} / \mathrm{L}$ for site 11 and from about 120 to almost $200 \mathrm{mg} / \mathrm{L}$ for site 26. During 2012-18, when large volumes of water were being discharged from Devils Lake, the trends in with-outlet concentrations for site 11 were much higher during July through February compared to the trend in no-outlet concentrations (fig. 1.2B) as a result of the high flow ratios for that site (fig. 1.1). For example, in 2012, the with-outlet trend peaked at about $700 \mathrm{mg} / \mathrm{L}$, more than double the no-outlet trend of about $300 \mathrm{mg} / \mathrm{L}$ (fig. 1.2B). Although with-outlet concentrations for site 26 during 2012-18 were elevated compared to no-outlet concentrations, the effect of the outlet was much less compared to site 11 because of the much lower flow ratios. The trend in with-outlet concentrations for site 26 peaked about 50 to $100 \mathrm{mg} / \mathrm{L}$ higher during most years compared to no-outlet concentrations; however, 


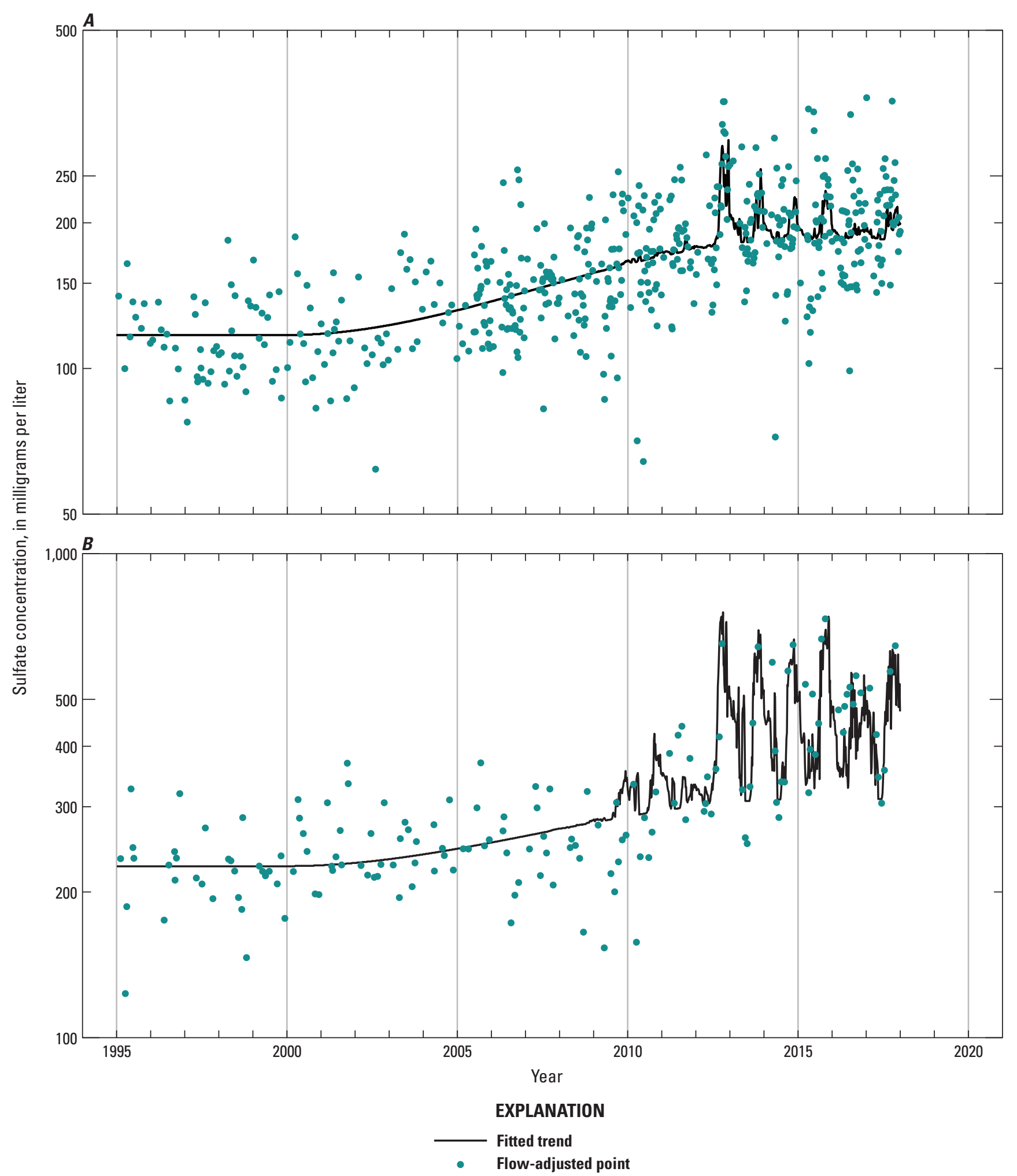

Figure 1.2. R-QWTREND plots of flow-adjusted points and fitted trend. $A$, for Red River of the North at Emerson, Manitoba; $B$, for Sheyenne River near Kindred, North Dakota. 
with-outlet concentrations during January through July were virtually equal to no-outlet concentrations because of the low flow ratios during that time (fig. 1.1).

The time-series model for with-outlet concentrations (eq. 1.9) was used for each site downstream from the outlets to determine the trend in annual flow-averaged geometric mean concentration (FAGMC; eq. 1.14), with and without the Devils Lake outlets. The results for the recent trend period for sulfate, chloride, and total dissolved solids for sites 11,15 , and 26 are shown in figure 1.3. For sulfate (fig. 1.3A), the effect of the Devils Lake outlets on the annual FAGMC was large for the Sheyenne River (site 11). For that site, the with-outlet FAGMC was more than $100 \mathrm{mg} / \mathrm{L}$ higher compared to the no-outlet FAGMC during 2012-18. This difference was larger than the trend in no-outlet FAGMC, which increased by a little less than $100 \mathrm{mg} / \mathrm{L}$ during the analysis period. The effect of
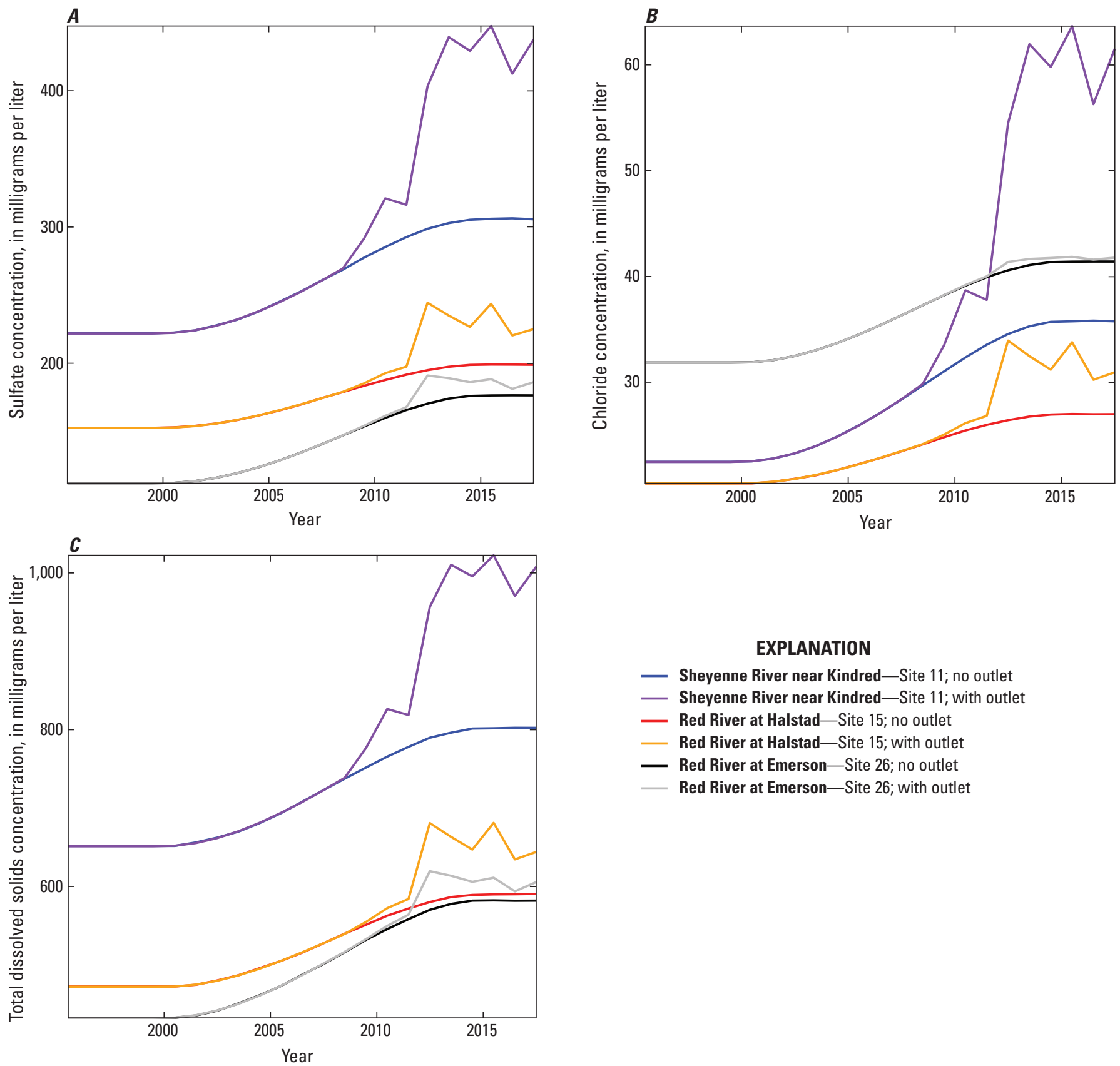

EXPLANATION

- Sheyenne River near Kindred-Site 11; no outlet

- Sheyenne River near Kindred-Site 11; with outlet

— Red River at Halstad-Site 15; no outlet

— Red River at Halstad - Site 15; with outlet

- Red River at Emerson-Site 26; no outlet

— Red River at Emerson—Site 26; with outlet

Figure 1.3. Comparison of trends in annual flow-averaged geometric mean for constituent concentrations evaluated for the recent period (2000-15) for no-outlet conditions and with-outlet conditions at selected sites downstream from the Devils Lake outlets in the Red River of the North Basin. $A$, sulfate; $B$, chloride; $C$, total dissolved solids. 
the Devils Lake outlets on the FAGMC was less for the two main-stem sites (15 and 26) than for the Sheyenne River. For the first main-stem site (15), during 2012-18, the with-outlet annual FAGMC for sulfate was about $40 \mathrm{mg} / \mathrm{L}$ higher compared to no-outlet conditions, which was similar to the trend in no-outlet FAGMC, which increased by about $50 \mathrm{mg} / \mathrm{L}$. For the binational site (site 26), the effect of the outlets was less than for site 15. For with-outlet conditions, FAGMC during 2012-18 was about $20 \mathrm{mg} / \mathrm{L}$ higher compared to no-outlet conditions. This difference was small compared to the nooutlet trend, which increased by about $75 \mathrm{mg} / \mathrm{L}$.

The results for chloride concentration (fig. 1.3B) were similar to the results for sulfate. For site 11, the with-outlet FAGMC for site 11 was much higher during 2012-18 compared to no-outlet conditions, with a difference of about $30 \mathrm{mg} / \mathrm{L}$, more than doubling the no-outlet concentration. This difference was much larger than the no-outlet trend, which increased by about $15 \mathrm{mg} / \mathrm{L}$. The difference in annual FAGMC between with-outlet and no-outlet conditions for site 15 (about $10 \mathrm{mg} / \mathrm{L}$ ) was similar to the no-outlet trend for that site, and the difference for site 26 (only about $2 \mathrm{mg} / \mathrm{L}$ ) was small compared to the no-outlet trend (about $10 \mathrm{mg} / \mathrm{L}$ ). Similarly, for total dissolved solids (fig. 1.3C), the difference between with-outlet and no-outlet conditions for site 11 (about $200 \mathrm{mg} / \mathrm{L}$ ) was larger than the trend for no-outlet conditions (about $75 \mathrm{mg} / \mathrm{L}$ ). For site 15, the difference because of the outlets (about $50 \mathrm{mg} / \mathrm{L}$ ) was similar to the no-outlet trend, and for site 26 , the difference (about $20 \mathrm{mg} / \mathrm{L}$ ) was small compared to the no-outlet trend (about $100 \mathrm{mg} / \mathrm{L}$ ).

The decreasing effect of the outlets on concentrations with increasing distance from the outlets was related to a few factors; the estimated flow ratio decreases downstream because of tributary inflows and increased drainage area (fig. 1.1), discharge from the outlets occurs in summer with the largest ratios occurring for short periods of time in late fall to early winter, and, depending on the relative volume and constituent concentration of the tributaries, concentrations in the Red River may be diluted. Overall, discharge from the outlets resulted in moderate increases in the annual FAGMC of sulfate, chloride, and total dissolved solids at the first mainstem site downstream from the outlets (site 15) but only minimal increases at the binational site (site 26). The greatest effect on concentrations for the binational site (site 26) occurred for total dissolved solids in 2012 when the FAGMC increased by about 9 percent, but overall discharge from the outlets had minimal effect on the FAGMC of sulfate, chloride, and total dissolved solids at the binational site (site 26). For sites downstream from site 26, the outlets had negligible effect, and no distinction was made between with-outlet and no-outlet conditions for those sites.

It should be noted that the previous discussion is pertinent to long-term (multiyear) trends in the annual FAGMC. The effects of Devils Lake outlets on short-term (for example, daily) exceedances of water-quality objectives (WQOs) can be large even as far downstream as the binational site. This is illustrated for sulfate concentration in figure 1.4, which shows the flow-averaged probability of exceeding the sulfate WQO of $250 \mathrm{mg} / \mathrm{L}$ for the binational site (26). The flowaverage exceedance probability (the blue line) depends on the seasonal flow-related variability $\left(S\left\{F R V_{n}\right\}\right.$, eq. 1.13) and the model error ( $E$, eq. 1.9) in addition to the trend and, thus, can have a different seasonal pattern compared to the trend in flow-adjusted concentration (fig. 1.2). For the no-outlet conditions (fig. 1.4A), during 2012-18, there was about an equal (50-percent) chance of exceeding the WQO during late spring (late May to early June) and again during late fall (late November to early December) and a much smaller chance during the rest of the year. For with-outlet conditions (fig. 1.4B), there was a much higher and broader secondary peak in the exceedance probability in late summer and fall compared to no-outlet conditions; for example, during any given day during about August through December of 2012, there was about a 75 -percent chance of exceeding the WQO. The annual mean flow-averaged exceedance probability (the red lines in fig. 1.4) is interpreted as the expected proportion of time during the year that sulfate concentration exceeds the WQO. During 2012-18, there was a relatively large increase in the annual exceedance probability for with-outlet conditions compared to no-outlet conditions. For no-outlet conditions (fig. 1.4A), during $2012-15$, the annual exceedance probability was about 0.25 , meaning that under average flow conditions, the sulfate concentration is expected to exceed the WQO about 25 percent of the time, or about 3 months, each year. For with-outlet conditions (fig. 1.4B), during the same period, annual exceedance probabilities were about 0.1 higher, on average, compared to no-outlet conditions, meaning that the WQO was exceeded about 37 days ( 0.1 decimal year) more often compared to nooutlet conditions, with most of the extra exceedances occurring during late summer and fall (August-December).

The effect of the Devils Lake outlets on the annual exceedance probabilities for the binational site are shown in more detail in figure 1.5. The results for sulfate (fig. 1.5A), which are the same as the results discussed in the previous paragraph (fig. 1.4), indicated a moderate increase in the annual probability of exceeding the WQO as a result of the outlets. Compared to sulfate, the outlets had much less effect on the annual exceedance probabilities for chloride and total dissolved solids. For chloride (fig. 1.5B), there were relatively few exceedances (annual probabilities less than 0.1), or about 37 days per year either for no-outlet or with-outlet conditions. For total dissolved solids (fig. 1.5C), during 2012-18, for nooutlet conditions, there was a high annual probability (about 0.8 , or more than 300 days per year) of exceeding the WQO with a slight increase because of the outlet. 

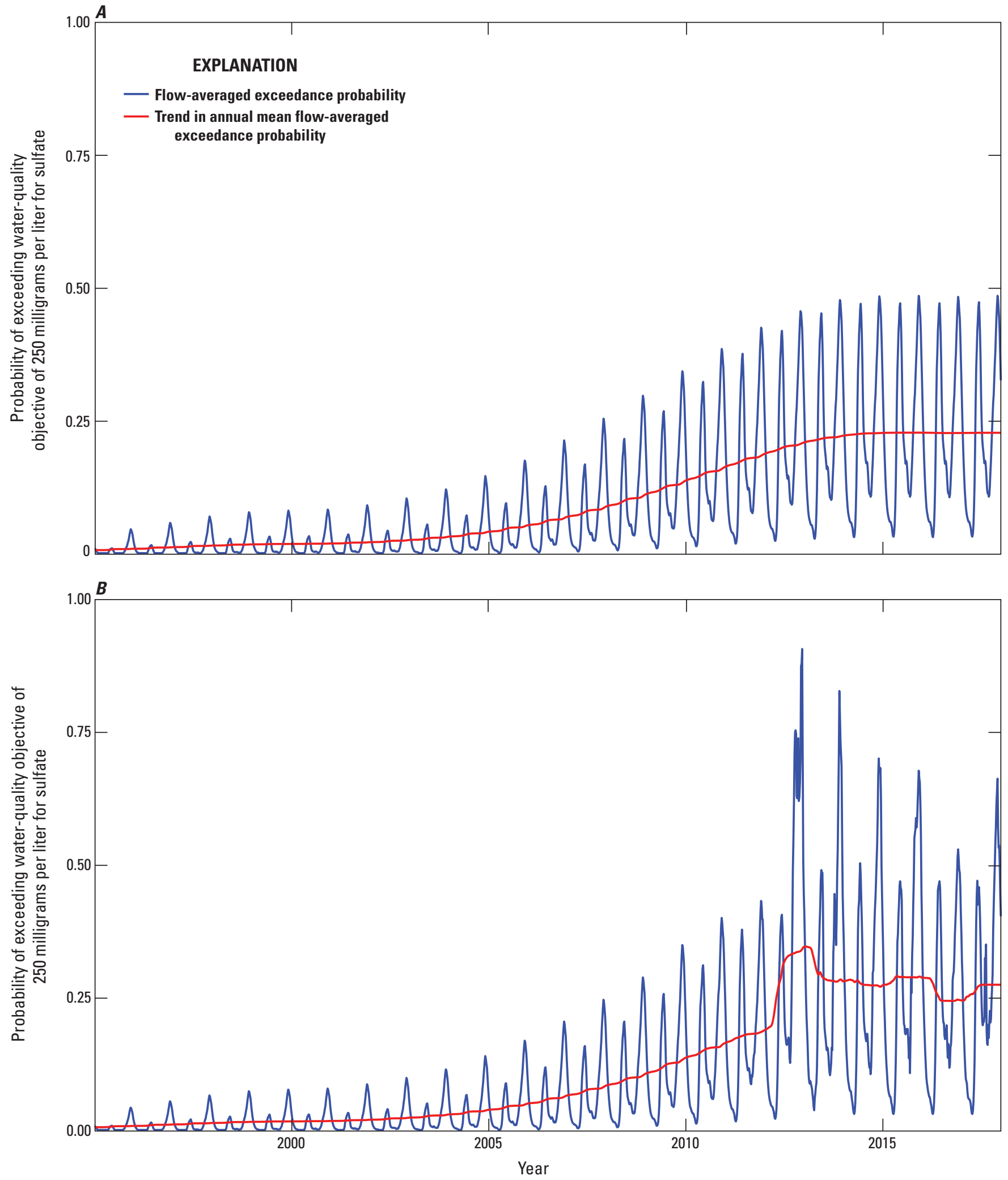

Figure 1.4. Flow-averaged exceedance probability and trend in annual mean flow-averaged exceedance probability evaluated for the sulfate water-quality objective of 250 milligram per liter during 2005-18 at the binational site, Red River of the North at Emerson, Manitoba, for sulfate. $A$, for no-outlet conditions; $B$, for with-outlet conditions. 


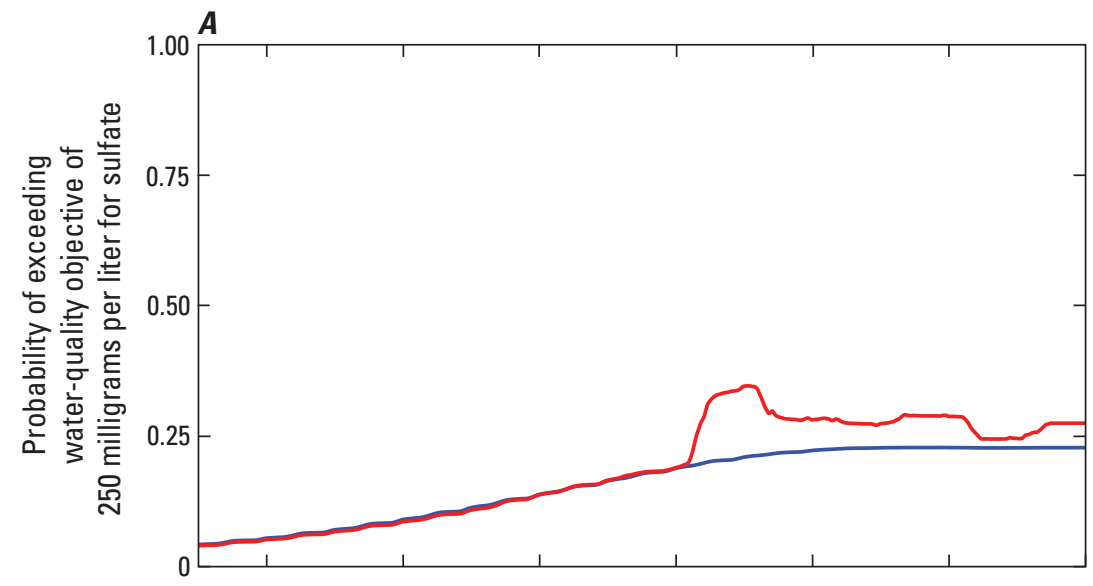

\section{EXPLANATION}

Trend in annual mean flow-averaged exceedance probability for no-outlet conditions

Trend in annual mean flow-averaged exceedance probability for with-outlet conditions
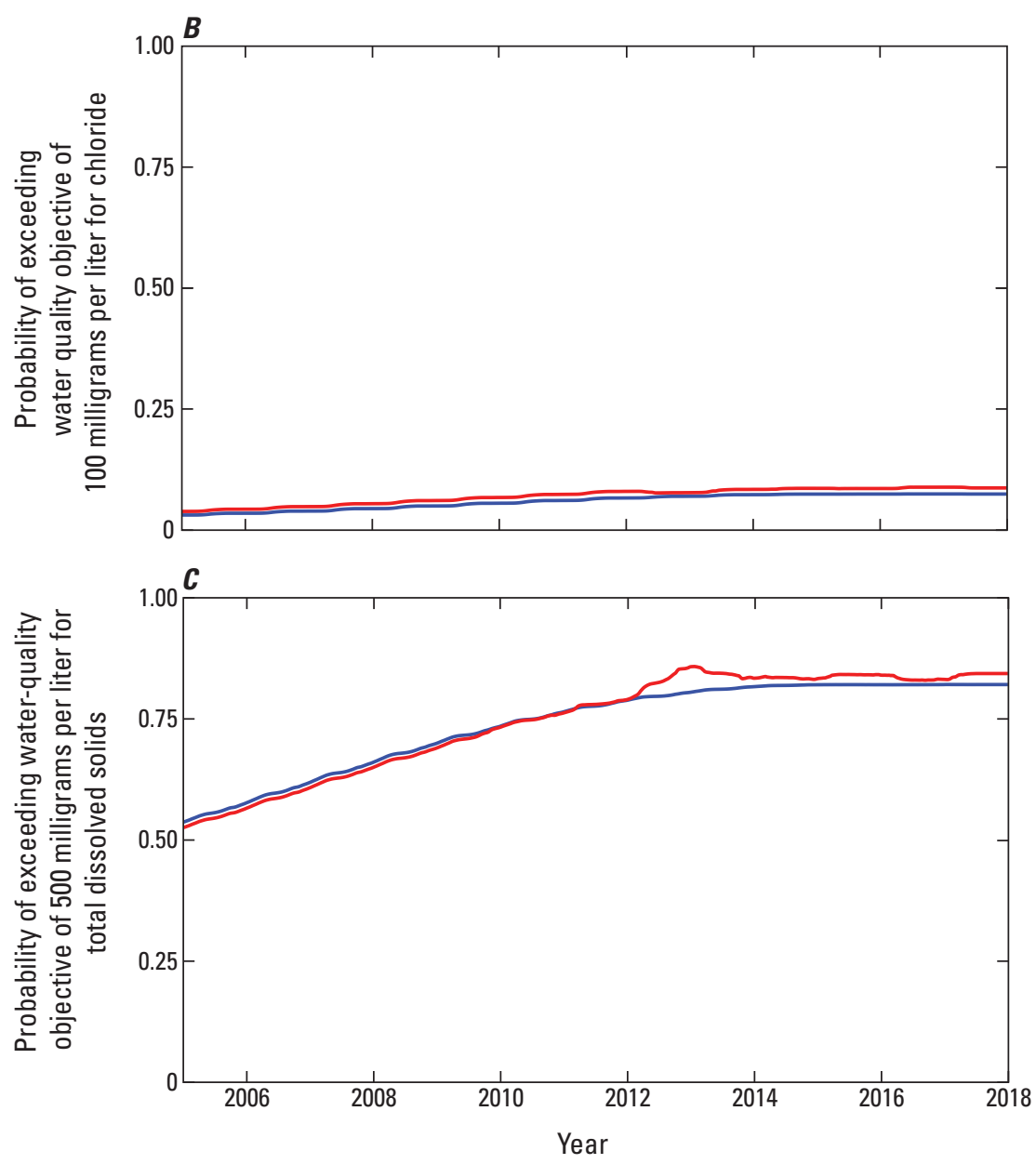

Figure 1.5. Trend in annual mean flow-averaged exceedance probability evaluated for constituent water-quality objectives during 2005-18 for no-outlet and with-outlet conditions at the binational site, Red River of the North at Emerson, Manitoba. $A$, sulfate; $B$, chloride; $C$, total dissolved solids. 


\section{References Cited}

North Dakota State Water Commission, 2019a, Devils Lake by the numbers: North Dakota State Water Commission Fact Sheet, 4 p., accessed September 19, 2019, at https://www.swc.nd.gov/pdfs/dl_fact_sheet.pdf.

North Dakota State Water Commission, 2019b, August 2019 Devils Lake outlets monthly discharge and water quality report: Bismarck, N. Dak., North Dakota State Water Commission, 13 p., accessed November 2, 2019, at https:/www.swc.nd.gov/basins/devils_lake/outlets/ discharge_monitoring/pdfs/2019_08.pdf.
Vecchia, A.V., 2008, Climate simulation and flood risk analysis for 2008-40 for Devils Lake, North Dakota: U.S. Geological Survey Scientific Investigations Report 2008-5011, 28 p. [Also available at https://doi.org/10.3133/ sir20085011.]

Vecchia, A.V., and Nustad, R.A., 2020, Time-series model, statistical methods, and software documentation for R-QWTREND_-An R package for analyzing trends in stream-water quality: U.S. Geological Survey OpenFile Report 2020-1014, 51 p., accessed May 2020 at https://doi.org/10.3133/ofr20201014. 

For more information about this publication, contact:

Director, USGS Dakota Water Science Center

821 East Interstate Avenue, Bismarck, ND 58503

1608 Mountain View Road, Rapid City, SD 57702

605-394-3200

For additional information, visit: https://www.usgs.gov/centers/dakota-water

Publishing support provided by the

Rolla Publishing Service Center 
